\title{
DESENVOLVIMENTO DE UM SISTEMA INTEGRADO DE SENSORIAMENTO E INTELIGÊNCIA FORENSE
}

\subsection{INTRODUÇÃO}

\subsection{Contexto}

\subsubsection{Situação criminal no Brasil}

A evolução humana, nos aspectos voltados ao desenrolar dos eventos sociais, e suas interações, em alguns casos, acarreta comportamentos indesejáveis das pessoas, muitas vezes até mesmo reprováveis, como é o caso do delito penal.

Destarte, ao longo de sua história a sociedade tem tomado diversas medidas de combate e de repúdio contra tais comportamentos, haja vista tais situações serem solapadoras da tranquilidade social, esta indispensável para o desenvolvimento e para a paz sociais, condições formadoras da pedra basilar do desenvolvimento humano.

A engenharia, como área do conhecimento humano, não poderia deixar de também ser empregada como ferramenta utilitária nas medidas de combate de tais mazelas, haja vista os invulgares conhecimentos que lastreiam tal formação.

No Brasil os índices de criminalidade atingiram valores elevados, nos permitindo citar, como exemplo, informação fidedigna, no caso dados publicados pela Secretária Nacional de Segurança Pública (SENASP, 2012), pertencente ao Ministério da Justiça, onde se vê que as taxas de homicídios por cem mil habitantes apontam para esta triste realidade.

Tal assertiva resta demonstrada na tabela abaixo relacionada, onde é possível se visualizar os números acima: 


\begin{tabular}{|c|c|c|c|c|c|c|c|c|c|c|c|}
\hline \multirow{3}{*}{$\begin{array}{l}\text { Grupos de } \\
\text { Estados segundo } \\
\text { qualldade dos } \\
\text { dachs }{ }^{\infty}\end{array}$} & \multirow[b]{3}{*}{ Unidades da Federaçáo } & \multicolumn{5}{|c|}{ Homicidlo doloso } & \multicolumn{5}{|c|}{ Latrocinio } \\
\hline & & \multicolumn{2}{|c|}{ Ns. acodubs } & \multicolumn{3}{|c|}{ Taxas a } & \multicolumn{2}{|c|}{ Ns. atsolulos } & \multicolumn{3}{|c|}{ Taxas of } \\
\hline & & $2010^{n}$ & 2011 & 2010 & 2011 & Varliarso $\mid$ sa & $2010^{n}$ & 2011 & 2010 & 2011 & Varlaço $\mid(4)$ \\
\hline & Nacional & 42684 & $\ldots$ & 22.9 & $\ldots$ & ... & 1.593 & .. & 0,8 & .. & .. \\
\hline \multicolumn{12}{|l|}{ Grupo 1} \\
\hline \multirow{15}{*}{$\begin{array}{l}\text { Alta qualldade } \\
\text { e allmenta } \\
\text { o SINESPJC } \\
\text { adequadamente }\end{array}$} & Aagoss & 2.127 & 2.342 & 68,2 & 74,5 & 9,3 & 36 & 36 & 1,2 & 1,1 & $-0,7$ \\
\hline & Amazonas & 916 & 1.062 & 28,3 & 30,0 & 14,2 & 48 & 43 & 1,3 & 1,2 & $\rightarrow, 0$ \\
\hline & Bzhila & 4.536 & 4.380 & 32,4 & 31,1 & $-4,0$ & 116 & 120 & 0,8 & 0,9 & 2,9 \\
\hline & Ceara & 2.647 & 2.623 & 31,3 & 20,7 & $-1,8$ & 48 & 76 & 0,8 & 0,9 & 66,9 \\
\hline & Dlstrtbo Fedaral & 657 & 704 & 25,6 & 27,0 & 5,5 & 139 & 44 & 5,4 & 1,7 & 68,8 \\
\hline & Espritito Ssanto & 1.626 & 1.589 & 48,3 & 44,8 & $-3,2$ & 16 & 24 & 0,5 & 0,7 & 48,6 \\
\hline & Golas & 98 & 987 & 16,3 & 16,1 & $-1,4$ & 29 & 44 & 0,5 & 0,7 & 49,8 \\
\hline & Mato Grosso & B81 & 944 & 28,7 & 20,7 & 6,9 & 47 & 49 & 1,5 & 1,6 & 2,9 \\
\hline & Mato Grosso do Sul & 451 & 424 & 18,4 & 17,1 & $-7,1$ & 13 & 18 & 0,5 & 0,3 & 44,5 \\
\hline & Paratea & 1.438 & 1.634 & 38,2 & 43,1 & 12,9 & 17 & 26 & 0,5 & 0,7 & 51,9 \\
\hline & Pernambuco & 3.243 & 3.251 & 36,9 & 36,7 & $-0,5$ & 122 & 78 & 1,4 & 0,9 & $-36,6$ \\
\hline & Filo da Jantiro & 4.418 & 4.009 & 27,6 & 24,9 & $-9,9$ & 146 & 116 & 0,9 & 0,7 & $-21,2$ \\
\hline & Flo Grande do Sul (5) & 1.650 & 1.718 & 15,5 & 16,0 & 3,6 & 74 & 82 & 0,7 & 0,8 & 10,4 \\
\hline & SSo Paulo & 4.321 & 4.194 & 10,5 & 10,1 & $-3,7$ & 253 & 316 & 0,8 & 0,3 & 23,9 \\
\hline & Sergipe & 629 & 671 & 30,4 & 32,1 & 5,6 & 20 & 24 & 1,0 & 1,1 & 18,7 \\
\hline \multicolumn{12}{|l|}{ Grupo 2} \\
\hline \multirow{3}{*}{$\begin{array}{l}\text { Babxa qualidade } \\
\text { e allmenta } \\
\text { o SINESPJC } \\
\text { adequadamente }\end{array}$} & Marantiso & 1.006 & 1.131 & 15,3 & 17,0 & 11,2 & 27 & 96 & 0,4 & 1,4 & 248,1 \\
\hline & Rondênla & 548 & 399 & 35,1 & 25,3 & $-27,8$ & 26 & 12 & 1,7 & 0,3 & $-54,3$ \\
\hline & Tocanths & 255 & 256 & 18,4 & 18,3 & $-0,9$ & 5 & 16 & 0,4 & 1,1 & 216,0 \\
\hline \multicolumn{12}{|l|}{ Grupo 3} \\
\hline \multirow{5}{*}{$\begin{array}{l}\text { Alta qua lldade e } \\
\text { náo allmenta } \\
\text { o SINESPJC } \\
\text { adequadamente }\end{array}$} & Acre |6) & $1 \notin 0$ & 138 & 24,9 & 18,5 & $-25,9$ & 14 & 11 & 1,9 & 1,5 & $-22,8$ \\
\hline & Mhas Gerals & 2.898 & 3.630 & 14,7 & 18,4 & 25,3 & 16 & 90 & 0,1 & 0,5 & 458,8 \\
\hline & Para & 3.370 & 2.800 & 44,5 & 37,5 & $-15,7$ & 223 & 138 & 2,9 & 1,8 & $-39,0$ \\
\hline & Parand $(\rho)$ & 3.276 & 3.085 & 31,4 & 29,3 & 6,4 & 101 & $\approx$ & 1,0 & 0,8 & $-13,4$ \\
\hline & Flo Grande do Norte & $B 0 \theta$ & $\ldots$ & 25,5 & ... & $\ldots$ & 13 & .. & 0,4 & .. & .. \\
\hline \multicolumn{12}{|l|}{ Grupo 4} \\
\hline \multirow{4}{*}{$\begin{array}{l}\text { Babxa qual Idade } \\
\text { e não allmenta } \\
\text { o SINESPJC } \\
\text { adequadamente }\end{array}$} & Amspa & 28 & 6 & 3,9 & 0,9 & $-77,4$ & 1 & - & 0,1 & - & - \\
\hline & Plau & 240 & $\ldots$ & 7,7 & ... & ... & 1 & .. & 0,0 & .. & .. \\
\hline & forama & $\approx$ & $\ldots$ & 17,3 & $\ldots$ & $\ldots$ & 3 & .. & 0,7 & .. & .. \\
\hline & Ssanta Cstarina & 504 & 738 & 8,1 & 11,7 & 44,8 & 41 & 39 & 0,7 & 0,6 & $-5,9$ \\
\hline
\end{tabular}

Tabela 1 - Ocorrências com morte registradas pelas Polícias Civis dos estados membros da Federação, por cada 100 mil Habitantes - Brasil nos anos de 2010 e $2011^{1}$

Confirmando a pesquisa anterior, o estudo apresentado pelo órgão das Nações Unidas encarregado do monitoramento da criminalidade no mundo

1 Fonte: Sistema Nacional de Estatísticas em Segurança Pública e Justiça Criminal (SINESPJC) / Secretaria Nacional de Segurança Pública (SENASP) / Ministério da Justiça; Instituto Brasileiro de Geografia e Estatística - IBGE; Fórum Brasileiro de Segurança Pública.

\section{Índices}

(1) Os dados informados correspondem ao volume de ocorrências policiais registradas.

(2) Grupos segundo qualidade estimada dos dados registrados (vide apêndice metodológico).

(3) Por 100 mil habitantes.

(4) Retificação das informações publicadas no Anuário Brasileiro de Segurança Pública, ano 5, 2011.

(5) Os dados de homicídio doloso para 2010 e 2011 no estado do Rio Grande do Sul incluem também homicídios culposos, que não os de trânsito.

(6) Os dados de homicídio doloso para 2010 e 2011 no estado do Acre incluem também lesão corporal seguida de morte.

(7) Os dados de homicídio doloso, latrocínio e lesão corporal seguida de morte para 2010 e 2011 no Paraná foram informados a partir do número de vítimas, e não de ocorrências. 
(United Nations Office on Drugs and Crimes - UNODC), referente ao ano de 2011, mostra que a taxa de homicídios dolosos coloca o Brasil entre um dos países mais violentos do mundo e, com um patamar de criminalidade muito acima dos níveis mundiais e, aceitáveis pelas Nações Unidas.

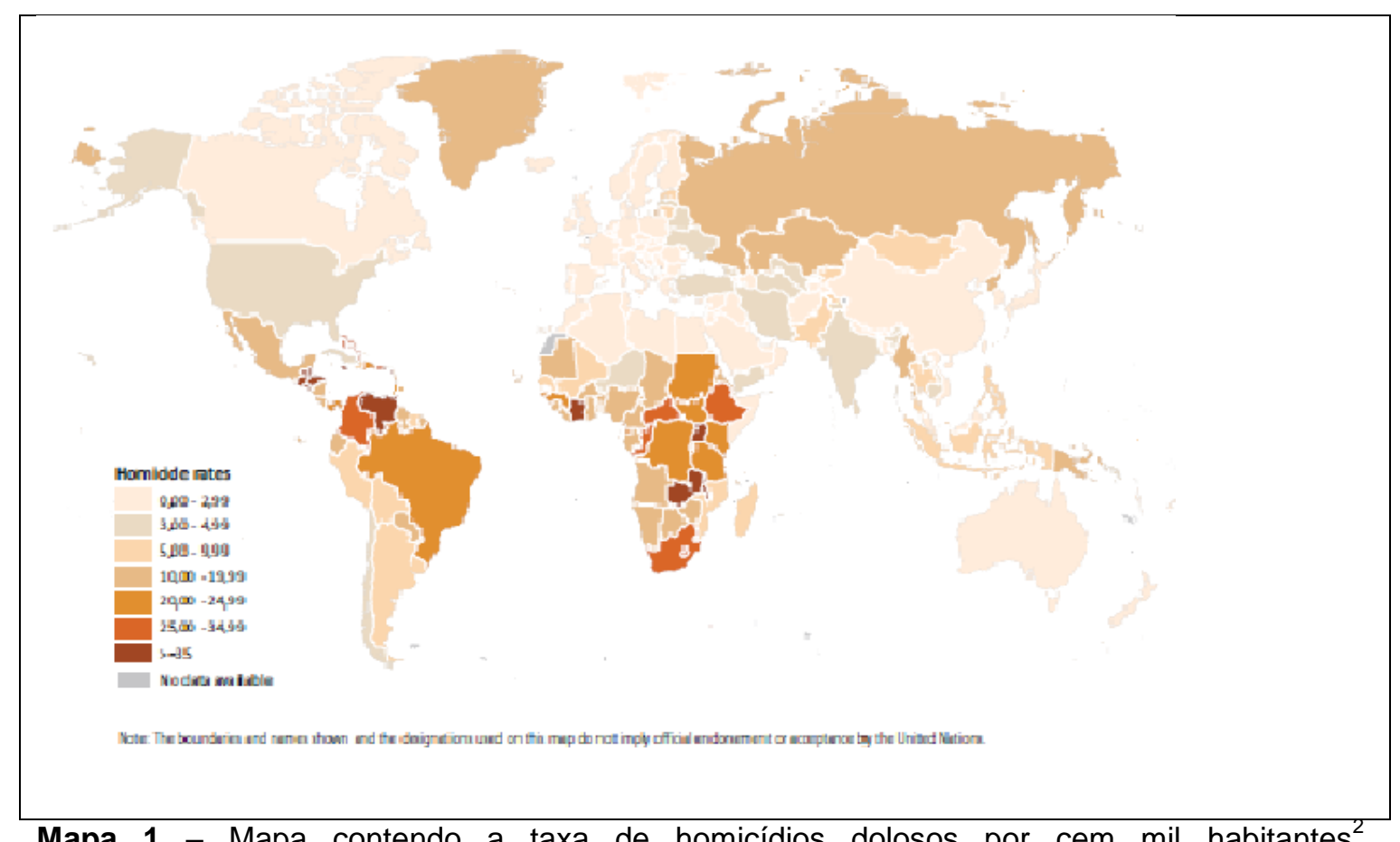

Mapa 1 - Mapa contendo a taxa de homicídios dolosos por cem mil habitantes ${ }^{2}$.

A pesquisa do Instituto de Pesquisa Econômica Aplicada (IPEA) denominada "Sistema de Indicadores da Percepção Social" sobre Segurança Pública, para o ano de 2010, mostra que esses índices altos de criminalidade são fortemente sentidos pela população brasileira e tem consequências graves no modo de vida do brasileiro com reflexos na economia e na educação.

\footnotetext{
${ }^{2}$ Fonte: GLOBAL STUDY ON HOMICIDE 2011 - UNODC (United Nations Office on Drugs and Crime)
} 


\begin{tabular}{|l|c|c|c|}
\hline & Muito medo & Pouco medo & Nenhum medo \\
\hline Centro-Oeste & $75,0 \%$ & $13,4 \%$ & $11,6 \%$ \\
\hline Nordeste & $85,8 \%$ & $8,2 \%$ & $6,0 \%$ \\
\hline Norte & $78,4 \%$ & $14,0 \%$ & $7,6 \%$ \\
\hline Sudeste & $78,4 \%$ & $10,9 \%$ & $10,7 \%$ \\
\hline Sul & $69,9 \%$ & $17,3 \%$ & $12,8 \%$ \\
\hline
\end{tabular}

Fonte: Pesquisa SIPS - Ipea, 2010

$\underline{\text { Tabela } 2}$ - Taxa de medo ${ }^{3}$

\subsubsection{Razões da criminalidade elevada}

As altas taxas de criminalidade no Brasil são históricas e têm suas raízes (Garrido 2006), em causas exógenas (sociais) ou endógenas (operacionais).

Como causas exógenas da criminalidade despontam como principais:

- Desigualdade Social (Beato 1998);

- Sistema legal anacrônico conduzindo a uma sensação de impunidade (Lopes 2000);

Como causas endógenas despontam como principais:

- Insuficiência do aparato policial (Brunet e Viapiana 2008);

- Uma crise de desempenho policial (Viapiana 2006).

Em outro estudo, Diniz e Estellita (2012) em seus estudos da segurança pública no Rio de Janeiro citam Soares (2003) que diz:

\footnotetext{
${ }^{3}$ Fonte:http://agencia.ipea.gov.br/images/stories/PDFs/SIPS/110330_sips_seguranapublica.pdf
} 
" diante de anos de omissão frente aos problemas de segurança pública, a polícia continua organizada para a defesa do Estado e não para os cidadãos, apresentando problemas estruturais, operacionais e de conduta, tais como:

a. Degradação institucional com modelo
gerencial obsoleto;

b. Desrespeito sistemático aos direitos humanos;

c. Relações perigosas com o crime organizado;

d. Corrosão de credibilidade;

e. Ineficiência investigativa e preventiva;

f. Falta de modernização técnica;

g. Postura reativa aos acontecimentos mesmo diante de um quadro de repetição regular."

Vários autores ligados às áreas Sociais, principalmente ao Direito, têm dedicado longos períodos de estudo na análise dos quatro primeiros itens listados acima. Por exemplo: Cathcart (1998) analisando a distribuição e emprego de recursos na área policial, relacionado ao primeiro item citado acima, encontra uma lacuna gerencial na produção da prova pericial ressaltando:

"É nesse sentido que se ressente a comunidade provedora da prova pericial quando, na ânsia de oferecer um bom "produto" aos operadores do direito, encontra obstáculos ditados por programas globais da administração pública diluidores dos recursos - humanos e materiais quando, para a necessária eficácia, deveriam ser direcionados para atividades específicas".

O estudo do Instituto de Pesquisas Econômicas (IPEA - 2011) mostrou que os itens "a", "b", "c" e "d" são associados e refletem nos baixos índices de confiabilidade policial conforme mostrado abaixo: 


\begin{tabular}{|l|c|c|c|c|}
\hline & Confia muito & Confia & Confia pouco & Não confia \\
\hline Centro-Oeste & $4,30 \%$ & $37,05 \%$ & $34,20 \%$ & $24,45 \%$ \\
\hline Nordeste & $5,80 \%$ & $24,10 \%$ & $43,45 \%$ & $26,70 \%$ \\
\hline Norte & $4,45 \%$ & $26,15 \%$ & $47,35 \%$ & $22,00 \%$ \\
\hline Sudeste & $3,00 \%$ & $21,80 \%$ & $45,10 \%$ & $30,05 \%$ \\
\hline Sul & $3,40 \%$ & $28,00 \%$ & $43,95 \%$ & $24,65 \%$ \\
\hline
\end{tabular}

Tabela 3 - Índice de confiabilidade policial

Por estarem os itens "a" a "d" mais ligados às áreas sociais não são o escopo deste trabalho e, que foca com mais profundidade os itens "e" a " $g$ ", os quais, por suas características particulares, podem ser objeto de estudo da área de ciências exatas tais como a engenharia, entre outras.

Assim, analisando com mais profundidade o item "e", Ineficiência investigativa e preventiva, podemos citar a mídia televisiva e jornalística que sucessivamente vem apontado à inoperância das polícias civis (Estado omisso) e, informam que decorrente da baixa eficiência na investigação e apuração dos casos criou-se um sentimento popular de impunidade permitindo que pessoas de baixa renda vivessem do cometimento de crimes, tais como: tráfico de drogas e furtos e que produzem como efeito colateral crimes violentos com severas consequências para as vítimas, tais como: roubos a mão armada, homicídios e latrocínio (praticar homicídio para efetuar roubo);

Um exemplo é a matéria jornalística encontrada na edição "on line" de 16 de Julho do jornal Folha de São Paulo, na qual se noticia que no estado de São Paulo, 95\% dos crimes ficam impunes.

SÃO PAULO - Uma pessoa que cometa um crime na capital paulista tem uma chance em 20 de ter de responder na Justiça (5,2\%). E mais da metade dos processos só é aberta porque o autor do crime foi pego em 
flagrante. Se isso não ocorrer, a chance de a investigação policial descobrir o criminoso é de apenas 1 em 40 (2,5\%).

Para Mazina, os índices revelam a baixa capacidade de investigação das polícias estaduais, reflexo da ideia de que o combate ostensivo ao crime deve ser priorizado. Isso tem consequências importantes, segundo 0 presidente do IBCCRIM. Os flagrantes, por exemplo, são priorizados, atingindo os pequenos criminosos que atuam nas ruas. As estruturas criminais, contudo, de receptação e encomenda, que fazem novos crimes acontecerem, permanecem intactas.

Outro exemplo pode ser visto no artigo denominado "Documentos revelam ineficiência policial", de 20 de Julho de 2008 do Jornal a Gazeta do Povo que afirma que o problema central nas investigações é a falta de elementos materiais probatórios:

\section{Sem provas}

A promotora Rosângela Gaspari, do Centro de Apoio das Promotorias Criminais do Ministério Público do Paraná, afirma que é comum a existência de inquéritos sem elementos probatórios suficientes. "Essa situação decorre, em especial, do grande aumento da criminalidade, que resulta em inúmeros feitos investigatórios sem que haja o mesmo crescimento do número de autoridades policiais e investigadores", comenta. "Com frequência verificamos muita demora na conclusão das investigações, o que acarreta consequências sérias no âmbito probatório."

Como consequência desta realidade, vários promotores públicos e juízes, reiteradamente, veem protestando da ausência de provas nos inquéritos policiais que têm causado o arquivamento indevido ou a absolvição por falta de 
provas face ao princípio legal da presunção de inocência (inciso VII do artigo 386 do decreto-lei no 3.689 , de 3 de outubro de 1941 - CPP).

Alguns juristas, como o Dr. Gelson Amaro de Souza, professor da Universidade Estadual do Norte do Paraná, em seu artigo de 20 de Março de 2011 para o periódico "Paginas de Direito", vão além e trazem à baila que um julgamento de mérito sem a presença de elementos materiais trata-se de uma "falácia".

De fato: a mídia, as vítimas, os promotores públicos, juízes, advogados e, principalmente a sociedade civil exigem uma modificação da situação, conforme pode ser observado na matéria jornalística denominada "Falta de investigação de homicídios resulta em fracasso institucional" do Jornal o Globo, de 04 de setembro de 2011 que diz:

Para o presidente da Associação dos Magistrados Brasileiros, o desembargador do Tribunal de Justiça de São Paulo Nelson Calandra, o arquivamento "é a ponta do iceberg": - Debaixo d'água está nosso sistema processual penal, que precisa ser mudado imediatamente. $O$ que esperar de uma testemunha que após um julgamento sai pela porta da frente de um tribunal ao lado do réu? Nosso sistema faz do réu sua excelência - diz o desembargador. Além disso, temos um inquérito policial que é uma peça de museu. Delegacias e peritos estão completamente sucateados. (grifo nosso).

\subsubsection{Realidade da Perícia Criminal no país}

Considerando-se que:

A legislação federal específica - Código de Processo Penal - CPP (DECRETO-LEI № 3.689, de 3 de outubro de 1941), que é o diploma legal que regulamenta parte das atividades da investigação policial e o processo penal em nosso país, determina em seu artigo 158 que todos os vestígios materiais 
encontrados no local sejam coligidos e interpretados, consoante exegese de seu texto, abaixo transcrito:

\section{DA PROVA}

\section{CAPÍTULO I}

\section{DISPOSIÇÕES GERAIS}

Art. 158. Quando a infração deixar vestígios, será indispensável o exame de corpo de delito, direto ou indireto, não podendo supri-lo a confissão do acusado. (grifo nosso)

Ainda, em decorrência do artigo 159 do já referido códex, artigo este com redação dada pela Lei Federal № 11.690 de 2008, os exames dos elementos materiais e sua arrecadação/coleta, é de responsabilidade exclusiva dos peritos oficiais, senão vejamos:

Art. 159. O exame de corpo de delito e outras perícias serão realizados por perito oficial, portador de diploma de curso superior. (grifo nosso)

No estado de São Paulo, a função de Perito Oficial que preceitua o CPP é desempenhada pelos Peritos Criminais, servidores públicos de natureza policial, ocupantes de cargos efetivos, nomeados mediante concurso e aprovação em curso específico na Academia de Polícia, todos integrantes dos quadros da SPTC - Superintendência da Polícia Técnico Científica está subordinada ao excelentíssimo senhor Secretário da Segurança Pública do Estado de São Paulo.

Tal é o rigor da exigência legal no tocante a este procedimento e sua exclusividade na atribuição da tarefa, que a já citada legislação pátria especializada (CPP), nos incisos I e II do artigo 6ํe também no artigo 169, corrobora veementemente tal exclusividade, senão vejamos: 


\section{DO INQUÉRITO POLICIAL}

Art. 60 Logo que tiver conhecimento da prática da infração penal, a autoridade policial deverá:

I - dirigir-se ao local, providenciando para que não se alterem o estado e conservação das coisas, até a chegada dos peritos criminais; (Redação dada pela Lei $n^{\circ}$ 8.862, de 28.3.1994) (Vide Lei $n^{\circ}$ 5.970, de 1973) (grifo nosso).

II - apreender os objetos que tiverem relação com o fato, após liberados pelos peritos criminais; (Redação dada pela Lei no 8.862, de 28.3.1994) (grifo nosso).

\section{CAPÍTULO II}

\section{DO EXAME DO CORPO DE DELITO, E DAS PERÍCIAS EM GERAL.}

Art. 169. Para o efeito de exame do local onde houver sido praticada a infração, a autoridade providenciará imediatamente para que não se altere o estado das coisas até a chegada dos peritos, que poderão instruir seus laudos com fotografias, desenhos ou esquemas elucidativos. (grifo nosso)

Parágrafo único. Os peritos registrarão, no laudo, as alterações do estado das coisas e discutirão, no relatório, as consequências dessas alterações na dinâmica dos fatos. (Incluído pela Lei no 8.862, de 28.3.1994) (grifo nosso) 
Vemos assim que não só o rigor na atribuição da exclusividade da tarefa restou expresso na lei federal especializada, mas também especificações no tocante ao grau da instrução dos Laudos Periciais, que podem vir a ser instruídos com fotografias, desenhos ou esquemas elucidativos, além da obrigatoriedade da discussão da alteração do "estado das coisas" na dinâmica do evento.

Em somatório a estes artigos, e de interesse para a presente pesquisa, temos ainda a inteligência do artigo 239 do mesmo diploma, que estabelece o conceito de "indício", como vemos na transcrição abaixo:

\section{CAPÍTULOX}

\section{DOS INDÍCIOS}

Art. 239. Considera-se indício a circunstância conhecida e provada, que, tendo relação com o fato, autorize, por indução, concluir-se a existência de outra ou outras circunstâncias. (grifo nosso)

De outro lado, temos diversas leis que tipificam os delitos penais, haja vista a normativa do inciso XXXIX do artigo 5o da Constituição da República, que recepcionou in totum o artigo primeiro do decreto-lei $n^{0} 2.848$, de 7 de dezembro de 1940 (Código Penal Brasileiro-CPB), abaixo descrito:

\section{TÍTULO I}

\section{DA APLICAÇÃO DA LEI PENAL}

(Redação dada pela Lei no 7.209, de 11.7.1984)

Anterioridade da Lei

Art. 1 - Não há crime sem lei anterior que o defina. Não há pena sem prévia cominação legal. (Redação dada pela Lei no 7.209, de 11.7.1984)

Face aos variados tipos penais descritos no Código Penal Brasileiro (CPB) e em leis especiais, aqueles, mormente classificados pelos 
jurisconsultos como "delitos materiais", ou seja, os que modificam o "estado das coisas" quando de sua pratica, deixando assim vestígios (materialidade), de interesse para o presente, os Peritos Criminais, na qualidade de Peritos Oficiais devem providenciar a anotação e registro nos locais de exame dos seguintes itens, principalmente:

Localização e situação das ocorrências;

Relatos (entrevistas) dos policias que efetuam a preservação do local, e das testemunhas diretas e indiretas;

Fotografias do local, dos vestígios e dos detalhes indispensáveis à compreensão da dinâmica dos fatos;

$>$ Desenhos esquemáticos (croquis) da situação e posição dos vestígios;

$>$ Vestígios presentes, tais como: impressões digitais, pegadas, marcas de pneumáticos, marcas de ferramenta empregadas para a prática do delito, armas, projetis, capsulas, restos de substância hematóide (sangue), esperma, fezes, tecidos humanos, tecidos, roupas, pertences íntimos, artigos de mobília, etc.

Cabe, portanto, ao Perito Criminal a árdua tarefa de trazer ao processo penal as provas materiais, descrevendo-as e interpretando-as, quando necessário, produzindo assim a denominada "PROVA TÉCNICA".

No entanto, Garcia (2012), em sua dissertação de mestrado denominada "AVALIAÇÃO DO SERVIÇO DE PERÍCIA CRIMINAL BASEADA EM CONFIANÇA INSTITUCIONAL", descreve uma trágica realidade, explanando:

"A ausência de legislação específica para as instituições de perícia criminal gera indefinições quanto à sua natureza, organização, atribuições e forma de atuação. 
Como consequência, também não há leis ou normas regulamentadoras que sirvam de referência para um controle de qualidade das atividades de perícia criminal como, por exemplo, padronização de metodologias ou cadeia de custódia. Da mesma forma, não existem mecanismos formais estabelecidos para avaliação de desempenho ou controle dos processos que envolvem esse serviço."

No mesmo diapasão Giovanelli e Garrido (2011) citam como causa principal da ineficiência investigativa, qual seja, o distanciamento, no Brasil, da Perícia Criminal da Ciência Real, pois, metodologicamente não preenchem os quesitos:

- Padronização na execução dos exames (ineficiente);

$>$ Produção cientifica (inexpressiva);

> Acompanhamento da comunidade cientifica balizadora (esta distanciada);

$>$ Formação técnica (esta comumente incompatível com técnicas modernas), e;

Acesso irrestrito a investigação e meios adequados para sua consecução.

Em relação ao último item (acesso aos meios de investigação) os pesquisadores citando outros pesquisadores (especificamente para o Estado do Rio de Janeiro) salientam a falta de equipamentos modernos no local de investigação:

"Os meios de investigação aqui citados referem-se à infraestrutura de laboratórios, bem como a existência e adequabilidade de materiais e equipamentos necessários ao manuseio de vestígios encontrados em locais de crime que são os objetos de estudo do perito. A falta de recursos e tecnologias nos Institutos de Criminalística é bem 
conhecida. Rio de Janeiro, DESLANDES et al. (2003, p.124)."

E afirmam que:

".... a falta de equipamentos e insumos básicos nos órgãos periciais do estado impedem que seja elaborado um laudo com qualidade. Após sete anos, um outro estudo realizado sobre o inquérito policial no Rio de Janeiro mostrou que os laudos produzidos pelo Instituto de Criminalística têm baixo potencial esclarecedor, concluindo que não havia recursos técnicos que oferecessem subsídios para a investigação (MISSE, 2010, p 73-75).'

O "Diagnostico da Perícia Criminal" (2013), elaborado pela Secretária de Segurança Pública do Ministério da Justiça, comprova em números as atuais condições da perícia criminal, como pode ser observado abaixo:

\subsubsection{Acesso à banda larga.}

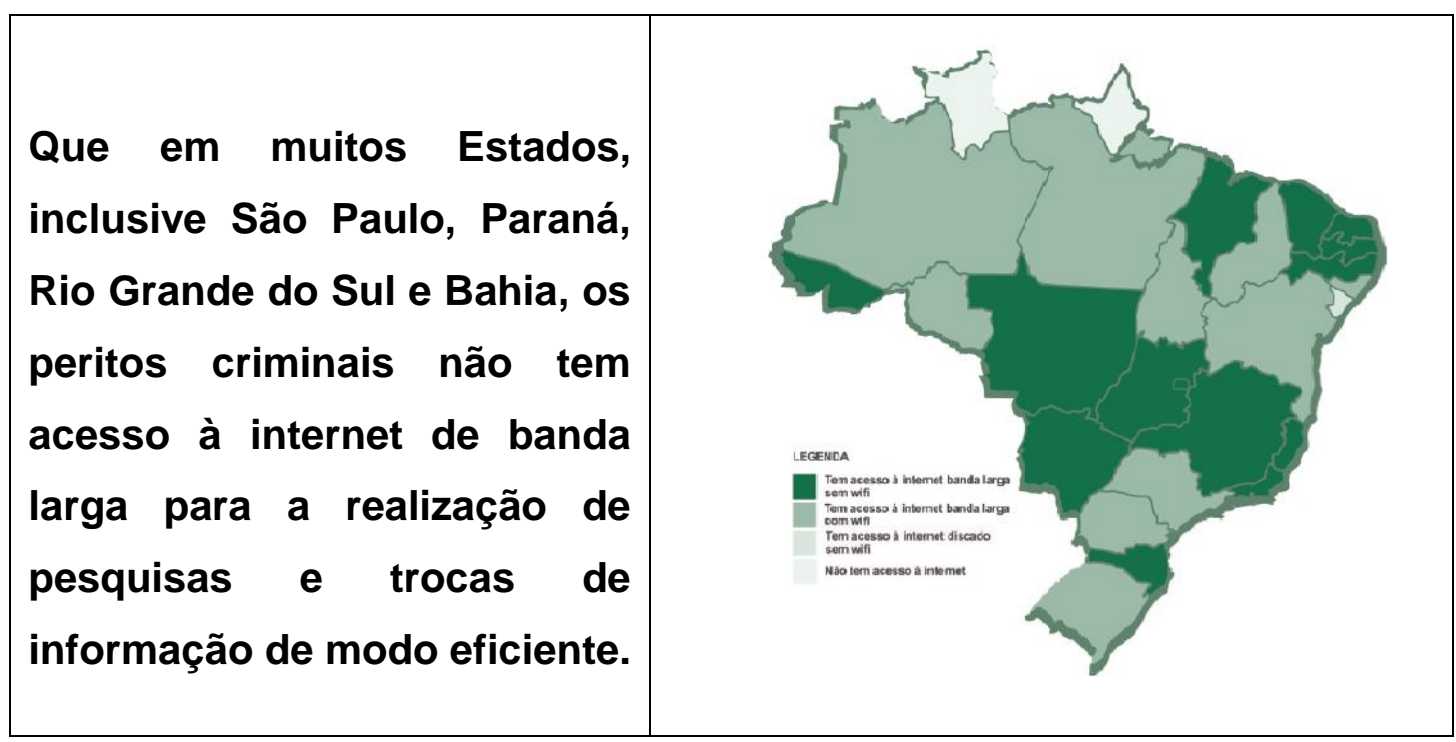

Mapa 2 - Acesso à banda larga 


\subsubsection{Gestão das informações.}

Os Institutos de Criminalística (Policias Técnicas), apesar de possuírem sistemas de informação computorizado, eles não efetuam:

O controle da movimentação das provas materiais arrecadadas nos locais de exame e a certificação de sua preservação (evidências - cadeia de custódia);

> Arquivo informatizado dos dados coletados em formato alfanumérico para que possam ser analisados;

Banco de dados digitais de tais provas materiais (evidências), em especial daquelas evanescentes, tais como impressão de pegadas, impressões palmares, marcas de ferramentas, impressão de pneumáticos, etc. Apenas em alguns Estados da federação o sistema de verificação de impressões digitais encontra-se em funcionamento;

$>$ Os equipamentos de exame de local, tais como câmeras fotográficas, GPS, luzes forenses, trenas a laser, etc., e de laboratório, tais como cromatografia, comparadores balísticos, etc., são em número insuficiente para as necessidades do dia a dia; 


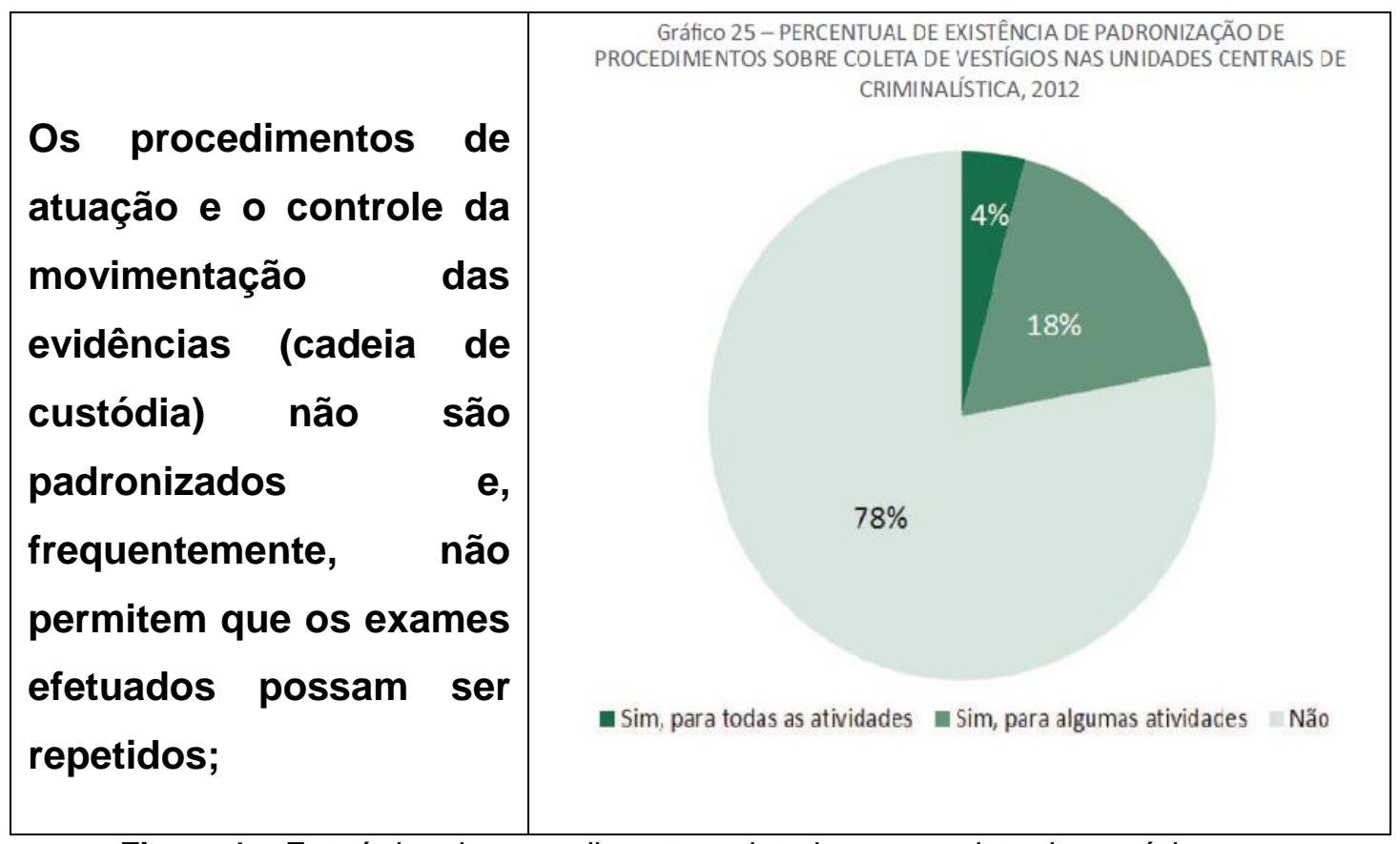

Figura 1 - Estatística de procedimentos adotados para coleta de vestígios

Os laudos produzidos, apesar de em alguns Estados da federação atingirem a casa da centena de milhares/ano e, por não possuírem mecanismos de controle de qualidade, terminam por se restringirem à descrição superficial dos locais onde se deu(ram) o(s) evento(s) delituoso(s) sob exame.

E, finalmente, o estudo citado acima conclui que face ao grande volume de solicitações e às deficiências estruturais, incluindo a falta de pessoal e qualificação técnica adequada, os serviços de perícia criminal não são capazes de acompanhar a demanda de tais solicitações com os padrões necessários.

Vivenciando o dia da dia dos peritos criminais plantonistas de uma região densamente povoada como o $A B C$ paulista, e que apresenta em uma elevada taxa de criminalidade, constata-se que:

Atendem a um excesso de ocorrências simultâneas e, dispõem de pouco tempo para efetuar uma coleta detalhada e abrangente dos vestígios atinentes ao fato investigado;

Não dispõem de equipamentos computacionais adequados para a coleta de 
informações de testemunhas, vítimas e suspeitos, posição dos vestígios (evidências), desenho de croquis, etc.;

> Não dispõem de equipamentos automatizados de coleta, análise e, classificação de vestígios, tais como impressões digitais, pegadas, impressões de pneumáticos, etc., terminando assim por coletar manualmente e sem sistemática alguns poucos elementos matérias.

Assim, os inquéritos policiais e, posteriormente, os processos judiciais penais, não raramente terminam desprovidos de elementos comprobatórios, teórica e legalmente indispensáveis à persecução penal.

Tal situação, em geral, pode ser ensejadora do arquivamento do procedimento pelo judiciário, vez que a este, não tendo opção, cabe o cumprimento da lei especializada (CPP), em seu artigo, que pedimos vênia em transcrever abaixo:

DAS NULIDADES E DOS RECURSOS EM GERAL TÍTULO I

\section{DAS NULIDADES}

Art. 564. A nulidade ocorrerá nos seguintes casos:

III-por falta das fórmulas ou dos termos seguintes:

b) o exame do corpo de delito nos crimes que deixam vestígios, ressalvado o disposto no Art. 167; 
Por outro lado, as informações coletadas em geral não são reduzidas a dados alfanuméricos analisáveis e, portanto, não são incorporadas a um banco de dados que permitiriam a formação de uma base de conhecimento (Expertise) e, por via de consequência, a determinação de padrões para a identificação de agentes delituosos contumazes (criminosos seriais).

\subsection{Justificativas da escolha do tema}

Observando os tópicos citados acima, conclui-se que a ausência de metodologia cientifica na perícia criminal brasileira, principalmente referente à tarefa de busca e coleta dos vestígios e informações nos locais de interesse durante as investigações, não permitem uma perfeita interpretação dos elementos materiais afetos ao delito sob exame, necessária aos inquéritos policiais, e não formam uma base técnico cientifica mínima.

Sem comprovação da materialidade do fato delituoso mediante a produção da prova técnica pelo Perito Criminal, ou ainda mesmo, com a produção da prova técnica sem base científica, o inquérito policial fica sem lastro, muitas vezes impossibilitando a denúncia do Ministério Público, que não raramente acaba por opinar pelo arquivamento do feito, dando assim cumprimento a alínea "b" do inciso III do artigo 564 do CPP, como acima transcrito.

Desse modo, acabam por impor uma baixíssima taxa de abertura de processos penais e, por via de consequência, acarretam situações em que a impunidade se faz presente, fator este aviltante para a tranquilidade social, esta indispensável para o desenvolvimento humano, conditio sine qua non é possível buscar tais valores. 


\subsection{Delineando uma solução}

Para o delineamento de uma solução, devido à extensão do tema, foram feitas algumas considerações, como veremos a seguir.

\subsubsection{Tipo Penal escolhido para 0 presente trabalho (paradigma)}

Inicialmente estabeleceu-se que o foco do presente trabalho, ou seja, o tópico do problema a ser abordado, seria o tipo penal "Furto", de tal sorte que, em estudos futuros, possa ser adaptado para outros tipos penais.

O "Tipo Penal" Furto, previsto no artigo 155 do Código Penal Brasileiro (CPB) foi escolhido como paradigma devido às características inerentes abaixo relacionadas:

> Elevada frequência (absoluta e relativa) da ocorrência do tipo;

> Exame complexo e sujeito a muitas variáveis;

> Necessidade da coleta simultânea de diferentes tipos de vestígios (impressões digitais, pegadas, marcas de ferramentas, marcas de pneumáticos, etc.), além de;

> Baixos índices de esclarecimentos quanto à autoria deste tipo penal.

Por exemplo, para o Estado de São Paulo, durante o ano de 2005 ocorreram 654.258 furtos (Senasp 2007).

\subsubsection{Definição do Tipo penal escolhido}

O tipo penal paradigma denominado "Furto" é definido no Código Penal Brasileiro (CPB) como: 


\section{Furto}

Art. 155 - Subtrair, para si ou para outrem, coisa alheia móvel:

Pena - reclusão, de um a quatro anos, e multa.

$\S 1^{\circ}$ - A pena aumenta-se de um terço, se o crime é praticado durante o repouso noturno.

$\S 2^{\circ}$ - Se o criminoso é primário, e é de pequeno valor a coisa furtada, o juiz pode substituir a pena de reclusão pela de detenção, diminuí-la de um a dois terços, ou aplicar somente a pena de multa.

$\S$ 3ํ - Equipara-se à coisa móvel a energia elétrica ou qualquer outra que tenha valor econômico.

\section{Furto qualificado}

$\S 4^{o}$ - A pena é de reclusão de dois a oito anos, $e$ multa, se o crime é cometido:

I - com destruição ou rompimento de obstáculo à subtração da coisa;

II - com abuso de confiança, ou mediante fraude, escalada ou destreza;

III - com emprego de chave falsa;

IV - mediante concurso de duas ou mais pessoas.

$\S 5^{\circ}$ - A pena é de reclusão de três a oito anos, se a subtração for de veículo automotor que venha a ser transportado para outro Estado ou para o exterior. 


\subsubsection{Quesitos oficiais}

Em função da definição legal do crime de "Furto" as autoridades legislativas estabeleceram em lei especializada os quesitos oficiais que, em tese, forneceriam os elementos materiais necessários à instrução do processo penal e constam no CPP, podendo ser também encontrados no "Manual Operacional da Policia Civil" do Estado de São Paulo (2012), neste último de forma sistematizada.

O artigo 171 do CPP, abaixo transcrito, estabelece:

\section{CAPÍTULO II}

DO EXAME DO CORPO DE DELITO, E DAS PERÍCIAS EM GERAL

Art. 171. Nos crimes cometidos com destruição ou rompimento de obstáculo a subtração da coisa, ou por meio de escalada, os peritos, além de descrever os vestígios, indicarão com que instrumentos, por que meios e em que época presume ter sido o fato praticado.

Assim sendo, temos, numa forma sistematizada pelo organismo policial acima referenciado, que os quesitos oficiais para o crime de furto podem ser relacionados do seguinte modo:

1. Qual a natureza do local observado?

2. Qual o meio usado para o acesso a esse local: com destruição ou rompimento de obstáculo, ou mediante escalada, uso de chave falsa ou outro?

3. Há, internamente, vestígios de destruição ou rompimento de obstáculos ou teria ocorrido escalada, uso de chave falsa ou outro meio tendente à subtração de coisa?

4. Em que época se presume tenha ocorrido o crime?

5. Houve emprego de instrumento ou instrumentos? Quais? 
6. Existiam vestígios, marcas, objetos ou documentos ou outros que venham a permitir a futura identificação do autor ou autores?

Basicamente, os quesitos se restringem à descrição de informações dos elementos visualmente observáveis referentes ao modo de operação do criminoso e, exceto o quesito "escalada" que necessita da realização de uma medição direta da altura do obstáculo vencido, os demais quesitos prescindem de maiores aferições.

A resposta aos quesitos deve ser parte do corpo do laudo, no entanto, não foi estabelecido se através de respostas diretas as questões ou através de redação corrente.

\subsubsection{Procedimento usualmente empregado na realização de pericias em locais de furto}

Não há uma normatização para a realização dos exames no local de crime e, por não haver, cada Perito Criminal adota uma sequência própria para a realização dos exames se utilizando dos quesitos oficiais como linha geral para a coleta das informações e sua transcrição.

Assim, mormente os peritos criminais optam por:

> Anotar as informações observadas em cadernos, ou;

$>$ Preenchem lacunas em um questionário que tem como modelo o laudo, ou;

> Em razão do advento das funções "macros" nos editores de texto, o modo mais frequente é o uso de questionários pré-elaborados em papel que contém questões que seguem os quesitos oficiais com as alternativas mais frequentes em cada região em que o Perito Criminal labora, simplesmente preenchendo 
com um "X" a alternativa porventura encontrada no exame.

Em todos os modos as informações coletadas são meramente descritivas e, apesar de seguirem um linguajar "aparentemente" técnico, em face da ausência de normatização, as palavras usadas na lavratura do laudo podem variar de perito para perito e, de lugar para lugar, considerando-se ainda a riqueza de nossa língua.

Deve-se salientar que as informações coletadas não são dados matemáticos passíveis de classificação e catalogação. Assim, a comparação e análise das informações "brutas" exigem trabalho manual e demorado para a identificação de padrões (modus operandi) e, por conseguinte, a busca do agente delituoso (criminoso serial).

\subsubsection{Elaboração dos Laudos periciais}

Independentemente de como o exame é efetuado, a redação do laudo é realizada manualmente pelo perito fora do horário de seu plantão e, muitas vezes, com recursos próprios (computadores e impressoras) e, sem a participação de auxiliares ou secretárias.

Para agilizar a edição, a maioria dos peritos utilizam editores de texto com "mascaras" (textos pré-escritos e disponíveis em arquivo), com lacunas a serem preenchidas ou funções "macros" acionadas por comandos pré- estabelecidos.

\subsection{Medições do desempenho da realização dos exames de furto}

\subsubsection{Considerações iniciais}


Como no Estado de São Paulo as equipes de criminalística se compõem de um Perito Criminal e um Fotógrafo Técnico-Pericial algumas considerações iniciais devem ser feitas:

$>$ Os trabalhos de coleta de informações verbais e vestígios são de incumbência especifica do Perito Criminal, podendo o Fotógrafo Técnico-Pericial auxilia-lo;

- A coleta de imagens (fotografias) é de incumbência do Fotógrafo Técnico-Pericial sob direta supervisão do Perito Criminal;

Dentro de uma determinada circunscrição (área de atuação do Perito Criminal), que pode compreender várias cidades e cujas populações somadas podem ultrapassar milhões de habitantes, as equipes de plantão executam todos os exames previstos no código penal que deixam vestígios (homicídios, furtos, acidentes de transito, etc);

Em face das circunstâncias incomuns de cada circunscrição, assim como seu tamanho, as características de cada um dos locais examinados podem variar sobremaneira para um mesmo tipo penal, tornando ainda mais trabalhoso o serviço de coleta e catalogação dos vestígios (evidências), e das informações de interesse.

\subsubsection{Realização de verificação exploratória inicial}

Em março e abril de 2011, com o apoio de quatro equipes de criminalística da Equipe de Perícias Criminalísticas de São Bernardo do Campo (EPC/SBC), compostas por Peritos Criminais e por Fotógrafos TécnicoPericiais, foi efetuado um teste exploratório para a medição do tempo empregado na realização dos exames de local de furto e a identificação de fatores relevantes que pudessem auxiliar na elaboração de uma solução. 
Cada equipe foi acompanhada por um período de doze (12) horas (que correspondem ao período de um plantão) em dias diferentes da semana (segunda-feira, terça-feira, quinta-feira e sexta-feira) e, apenas nos casos de "furto", os tempos gastos nos exames foram cronometrados a partir do momento da chegada ao local dos fatos até a finalização do procedimento de campo. Foi também questionado a cada perito o tempo médio utilizado para a confecção do Laudo pericial.

O perito número um (1) com cerca de vinte (20) anos de experiência na área e um dos idealizadores do sistema em desenvolvimento, que realizou os exames na segunda-feira, completou cinco exames com o tempo médio de vinte e três (23) minutos. Dos quatro peritos que participaram do exame, apenas este adotou o modo de anotação das informações e dados medidos diretamente em um caderno comum e, não coletou qualquer vestígio material.

O segundo perito, com cerca de quinze (15) anos de experiência, acompanhado na terça-feira, utilizou folhas impressas com um questionário com questões que tinham campos de preenchimento manual. Realizou apenas um (1) exame no período e utilizou quatorze (14) minutos, porém, não coletou qualquer vestígio.

O terceiro perito, com cerca de doze (12) anos de experiência, na quinta-feira, utilizou um questionário com múltiplas alternativas que continha como base os quesitos oficiais, porém, adicionalmente apresentava questões sobre a localização e situação do imóvel e questões sobre informações obtidas através das oitivas de testemunhas. As questões tinham um número maior de alternativas, pois, previam também a ocorrência de padrões com frequência muito reduzida. Realizando três exames teve um tempo médio de trinta e dois (32) minutos, porém, em uma das ocorrências devido à complexidade e, ao fato que foram colhidas uma impressão digital e uma marca de impressão de pegada humana, o tempo gasto total foi de quarenta e oito (48) minutos, o que deslocou o tempo médio para um patamar fora do previsto;

O quarto perito, com experiência profissional cerca de doze (12) anos, na sexta-feira, utilizando um texto baseado no laudo com lacunas a 
preencher realizou três (exames) e teve o tempo médio de vinte e três (23) minutos. Não foram colhidos vestígios materiais.

Considerando-se a inexistência tanto de metodologia quanto de padronização observou-se que cada equipe atuou de forma e em sequência diferente das demais e, devido à diversidade e variação da complexidade dos locais, os tempos medidos variaram sensivelmente impossibilitando uma comparação de desempenho entre as equipes.

Sobre o tempo gasto na confecção dos Laudos as respostas dadas foram imprecisas, pois, os peritos informaram que nunca atentaram ao tempo gasto, e afirmaram que o tempo gasto variava de dez (10) a vinte (20) minutos em função da complexidade do exame. Com tal informação, baseada no tirocínio desses peritos, adotamos como referência o tempo médio de quinze (15) minutos.

Não cabia ao objetivo da verificação exploratória analisar a qualidade das informações coletadas dos exames realizados e dos laudos emitidos, porém, observou-se que as informações contidas nos Laudos eram insuficientes para, por exemplo, o emprego de geo-referenciamento das informações, haja vista a inexistência de coordenadas geográficas ${ }^{4}$.

\subsection{Solução Proposta}

Analisando o contexto e a verificação exploratória inicial, para se buscar a otimização da atividade tornou-se claro a necessidade de sua padronização, sugerindo-se dotar as Policias Cientificas brasileiras de:

\section{Metodologia cientifica com normatização dos procedimentos da coleta de informações, assim como de dados numéricos, analise, classificação,}

\footnotetext{
${ }^{4}$ Para o geo-referenciamento o uso somente do endereço mostrou-se insuficiente em ocasiões anteriores devido à existência de irregularidades na distribuição geográfica. Por exemplo, no mesmo bairro observou-se a existência de duas ruas com o mesmo nome, etc.
} 
catalogação e elaboração de Laudos Periciais;

- Emprego de um sistema computacional que integre em tempo real os trabalhos de campo e os trabalhos realizados nos escritórios locais das policias cientificas, onde se dá a análise e elaboração dos Laudos;

$>$ Adequar um equipamento de computação móvel (Tablet, notebook ou smartphone) para agilizar a coleta de informações em campo e a comunicação com sua base;

$>$ Desenvolver um protocolo de comunicação que interligue os diferentes equipamentos; (a unidade móvel utilizada em campo com o "desktop" da base policial técnico-científica);

> Desenvolver a arquitetura da base de dados para permitir que os dados novos sirvam de referência de comparação futura (formação de expertise), $\mathrm{e}$;

> Agilizar a elaboração de Laudos periciais;

1.6 Parâmetros adotados na arquitetura do sistema integrado

\subsubsection{Componentes do sistema integrado}

Em decorrência das premissas listadas acima desenhou-se um sistema composto de quatro partes essenciais:

1. Conjunto de dispositivos de computação móvel;

2. Equipamentos periféricos para a coleta de informações (máquina fotográfica, microscópio, microfone, etc.); 
3. Unidade de computação fixa para a análise principal e edição dos Laudos Periciais;

4. Periféricos para a complementação dos exames (impressora, scanner, etc.).

\subsubsection{Características do dispositivo de computação móvel em face do objetivo do presente trabalho}

Tais características devem ser focadas no objetivo do presente trabalho, que busca:

Agilizar a coleta dos vestígios com a redução do tempo gasto;

> Efetuar a análise rápida e detalhada dos vestígios - sua eventual interpretação;

> Executar em tempo real a classificação dos vestígios;

> Permitir a criação de banco de dados alimentado continuamente;

> Classificação e disposição de tais informações para emprego como consulta simples (pontual), e seu preparo para inserção em sistema especializado para a guarda e tratamento destes dados:

Auxiliar na identificação em tempo real do(s) agente(s) delituoso(s);

Auxiliar na lavratura do Laudo Técnico-Pericial;

- Implementar a Cadeia de Custódia da prova com auxílio da informatização, já no local dos fatos;

Tendo os pressupostos acima, o dispositivo móvel deverá preencher os seguintes requisitos:

Facilidade de manuseio e baixo peso (ergometria);

Resolução da tela com capacidade para fácil visualização dos textos e imagens; 
Flexibilidade para a adição de periféricos e programas;

> Capacidade de registro de imagens (fotografias e vídeo) com resolução compatível com as fotos panorâmicas e de média aproximação e sons;

Arquivamento provisório das informações coletadas em um banco de dados interno (como medida de segurança);

Capacidade de Informar a posição geográfica;

Capacidade de se efetuar o preenchimento de formulários digitais e textos em tempo real;

Capacidade de receber e transmitir de forma segura as informações com a unidade de computação fixa;

> Capacidade de comunicar-se com periféricos, tais como maquinas fotográficas de alta definição, sensores externos, etc. através de cabos ou por comunicação sem fio;

Sistema operacional aberto que permita o desenvolvimento de novos aplicativos específicos;

\subsubsection{Características da Unidade de computação fixa}

A unidade de computação principal deverá preencher os seguintes pressupostos:

Capacidade de comunicação em tempo real com os dispositivos móveis e, adicionalmente, com outras unidades fixas em localidades próximas ou com a unidade central;

> Armazenamento permanente dos dados com preservação segura das informações coletadas;

> Analise dos dados coletados;

> Capacidade de impressão dos laudos técnicopericiais. 


\subsection{REVISÃO DA LITERATURA}

\subsection{Histórico}

A investigação policial tem como objetivos principais:

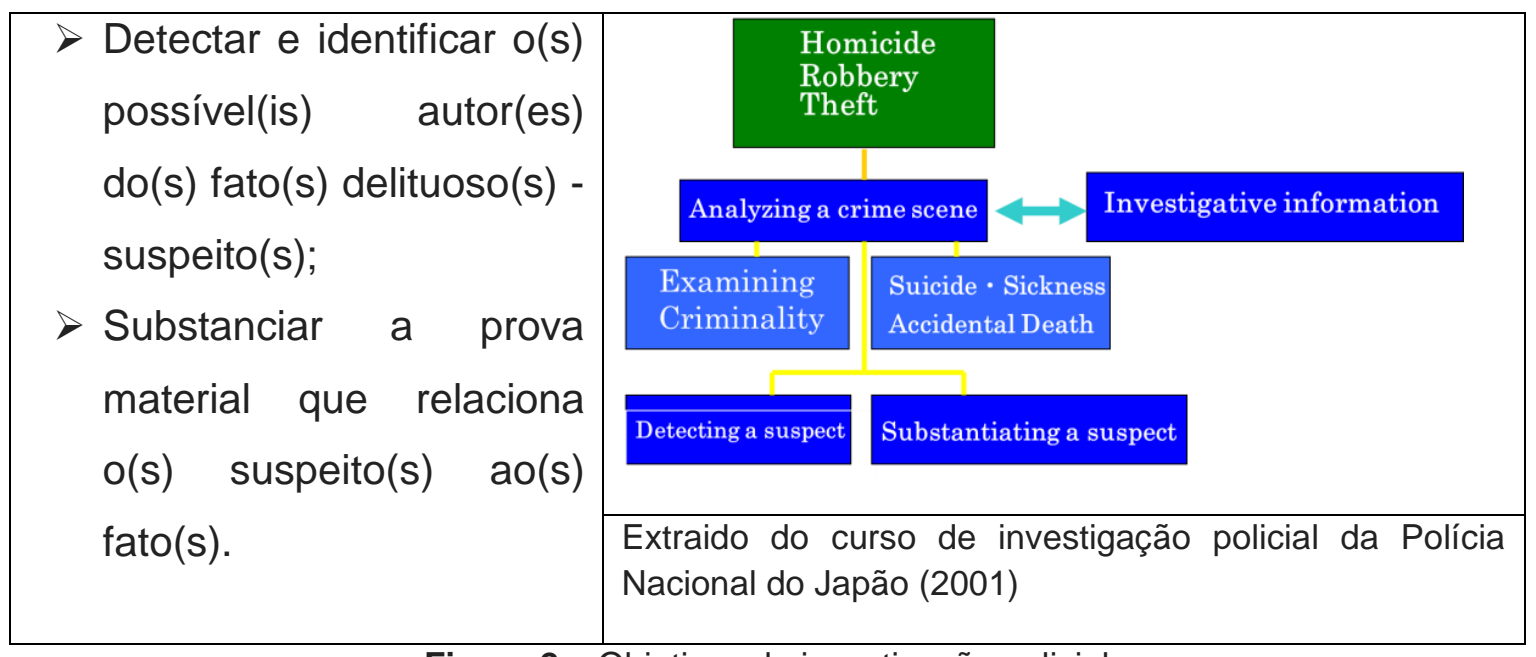

Figura 2 - Objetivos da investigação policial

Adicionalmente, determinar a dinâmica do crime especificando a sequencia de eventos, identificando os fatos agravantes ou atenuantes necessários para a individualização e justa atribuição da responsabilidade penal.

Porém, os princípios da investigação forense (pericial criminal) só foram criados no início do século XX por Hans Gross e Edmund Locard (Saferstein 2001) com a introdução dos conceitos de:

Uso de procedimentos padronizados;

Efetivação do isolamento da cena de crime, e;

Estabelecimento da "cadeia de custódia" das provas físicas 5 .

\footnotetext{
${ }^{5}$ Com a preservação dos vestigios colhidos para a realização de exames e material sufuciente de contraprovas para a realização de um segundo exame
} 
Utilizando esses conceitos, na primeira metade do século $X X$, acadêmicos observando as lacunas existentes nas investigações policiais da época criaram uma sequência didática, abaixo ilustrada, e testaram novas metodologias de coleta e analise de vestígios para garantir a precisão e a credibilidade cientifica necessária no substanciamento da prova.

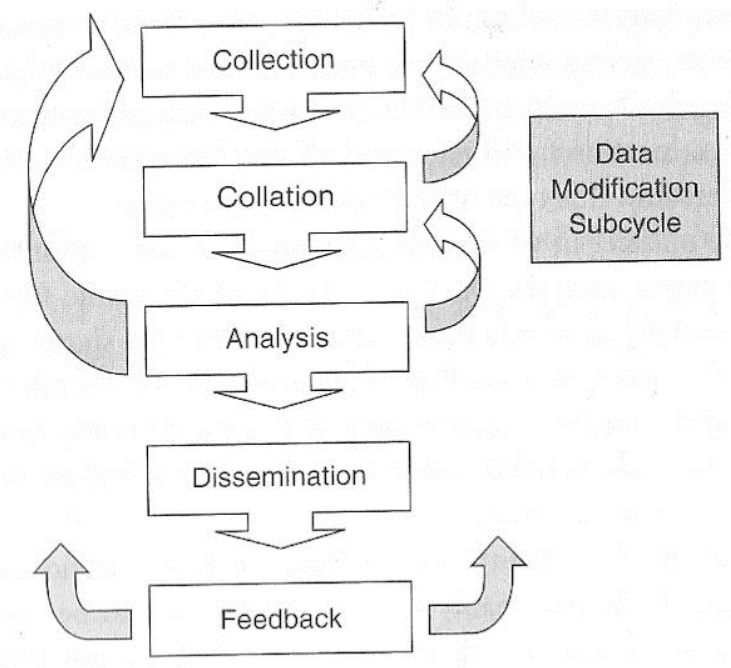

Figura $\mathbf{3}$ - Sequencia didática para coleção de vestígios

Fonte: Savelli, Lou. Basic crime scene investigation. USA, 2004

Como consequência, hoje em dia, os sistemas policiais modernos, inclusive os baseados no direito consuetudinário (common law), possuem para cada tipo penal um procedimento forense específico e que são suportados através das estruturas funcionais e operacionais de suas polícias. Estes procedimentos (Rodrigues, Silva e Truzzi 2010), são muitas vezes extensivamente detalhados nos manuais policiais ou ordens de serviço, porém, quanto mais detalhados podem ser de dificil execução e demorados para sua conclusão (Burrows et all 2005).

Entretanto, em tese, o detalhamento extensivo torna-se necessário devido, principalmente, à ocorrência de casos anômalos, ou seja, muito distantes dos padrões mais frequentes. 


\subsection{Metodologia da perícia criminal ao redor do mundo}

$\mathrm{Na}$ prática os peritos criminais $^{6}$ que efetuam exames de local começam suas atividades diárias (Dale e Becker 2007), ao receberem através dos sistemas de comunicação (verbal ou digital), o pedido inicial para a realização de um exame.

Ao chegarem ao local do crime, se as primeiras autoridades policiais que chegaram ao local não efetuaram o isolamento do local, a equipe pericial efetua 0 isolamento e, em seguida, (Lee, Palmach, Miller 2011), inicia os exames do local propriamente dito.

Conforme o manual: "Crime Scene Investigation- A Guide For Law Enforcement", editado pelo Departamento de Justiça dos Estados Unidos - (2013) os exames devem seguir uma sequencia de etapas que, na sua grande maioria, pode ser dividida em três fases principais, por nós esquematizadas na figura 4.

A figura 4 representa o modelo básico atual de como são realizados os exames em campo pelos Peritos Criminais.

1. A primeira fase (fase inicial - figura 4) é delimitada pelos procedimentos administrativos policiais em que o Perito Criminal preenche formulários sobre dados administrativos, posição ${ }^{7}$ e situação do local, colhe informações preliminares verbais (Giacalone 2011) sobre os fatos em investigação e, realiza uma vistoria inícial;

\footnotetext{
${ }^{6}$ O termo em Inglês é "Crime Scene Investigator"

${ }^{7}$ Hoje em dia, as coordenadas geográficas são obtidas por dispositivos individuais de geoposicioamento
} 


\section{FLUXO CONVENCIONAL DOS EXAMES ATUALMENTE PRATICADOS.}

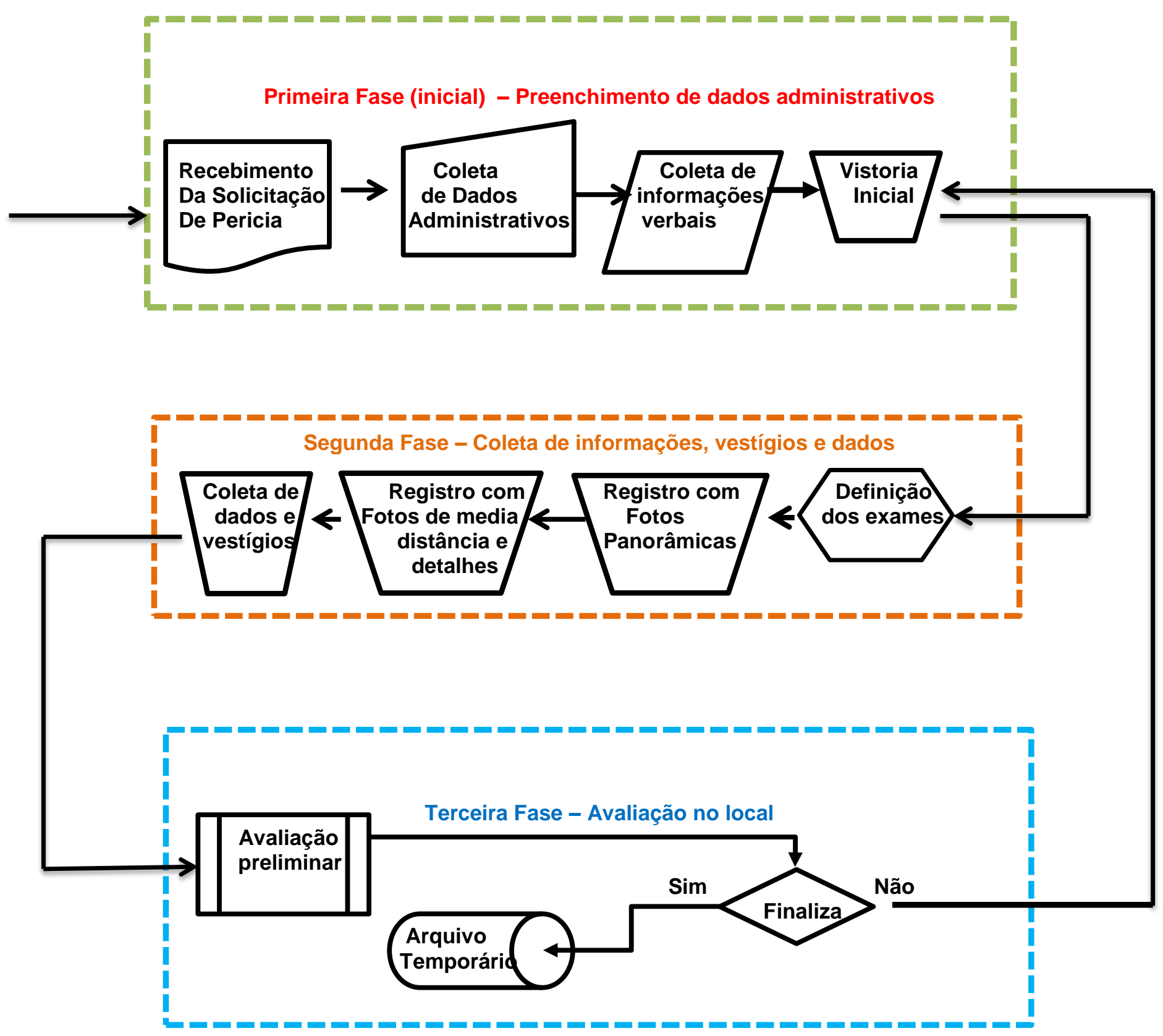

Figura 4 - Fluxo convencional dos exames periciais

2. Na segunda fase (figura 4), são obtidos os registros fotográficos e é efetuada a coleta de vestígios (evidências físicas) e o preenchimento dos formulários relativos ao tipo penal com os dados encontrados; 
3. Na terceira fase é efetuada uma avaliação inicial para se verificar a necessidade ou não de exames complementares e, caso necessário, novos exames são feitos e/ou medidas são implementadas para garantir tais exames.

Os exames realmente em si, começam com a vistoria inicial para conhecer o local e identificar:

D As ações a serem tomadas;

$>$ A posição e situação dos vestígios visualmente observáveis colocando-se marcadores numerados;

> O registro visual inicial do local através de fotos panorâmicas para retratar as condições locais, e;

> Os croquis e esquemas para relacionar 0 local com o delito.

$\mathrm{Na}$ sequência, para correlacionar as possiveis evidências físicas facilmente observáveis com o local são feitas fotos de uma distância média ${ }^{8}$, de modo a garantir arquivo de imagem relativo à situação do "estado das coisas" registrando todo o campo onde se encontra inserido o local sob exame.

Em seguida, a vistoria principal se inicia com um exame mais detalhado, com a finalidade de se encontrarem vestigios latentes que porventura tenham relação com os fatos em investigação.

Para registrar com maior precisão e definição as condições e situações de evidências encontradas, inclusive as latentes, são feitas fotografias com aproximação ${ }^{9}$ da imagem e/ou da máquina.

\footnotetext{
${ }^{8}$ Mid-range photo

${ }^{9}$ Close-up photo
} 
Em seguida, os vestigios são colhidos, embalados, rotulados, catalogados e, registrados em um documento especifico, instalando-se a partir daí, a "cadeia de custódia" da prova.

$\mathrm{Na}$ unidade de criminalística afeta ao fato, os registros da cadeia de custódia e as fotografias obtidas no local por câmeras digitais são transferidos para computadores, enquanto os vestigios, quando necessário, são enviados aos laboratórios para a realização de medições e exames não destrutivos e destrutivos.

O relatório inicial ${ }^{10}$ é então redigido, descrevendo-se:

$>$ o procedimento adotado;

$>$ todas as informações coletadas em campo;

$>$ os resultados dos testes laboratoriais ${ }^{11}$;

> descrição da dinâmica do crime (quando possível), e;

$>$ possíveis autores (suspeitos relacionáveis).

No entanto, observa-se que esta sequência é realizada por diferentes agentes que muitas vezes não interagem entre si e, que utilizão dispositivos isolados independentes para o registro das informações e que podem, em alguns casos, gerar o extravio ou perda de informações e evidências importantes. Alem disso, as informações coletadas não se tranformam imediatamente em dados numéricos que possam ser analisados.

\subsection{Delineamento do Sistema Integrado}

\subsubsection{Dispositivos de computação móvel para a coleta de dados}

\footnotetext{
${ }^{10}$ Durante as investigações relatórios adicionais mais detalhados podem ser solicitados pelas autoridades responsáveis (exame complementar)

${ }^{11}$ Se houver
} 
Já em 2002 Gellersen, Schmidt e Beigl exposuram que o uso de dispositivos móveis de processamento com dimensões reduzidas (dispositivos móveis e pequenos artefatos de comunicação) com plataformas de sensores integrados permitem uma melhor interação dos seres humanos com 0 ambiente físico e Hinckley et al (2005) sugeriu que a arquitetura interna dos dispositivos móveis deveria ser projetada especificamente para permitir uma interação dinâmica entre o ser humano e a atividade pretendida.

A partir do surgimento dos equipamentos de telefonia celulares digitais inteligentes (Smartphones), os fabricantes têm desenvolvido sucessivos dispositivos de comunicação sem fio com tecnologia "3G" e, atualmente, com tecnologia "4G" com a capacidade de efetuar, além da comunicação de voz, o acesso à internet, a interação com documentos e formulários e a fotografia, com possibilidade de captura de imagens de video ("filmagem").

No entanto, os aparelhos de smartphones devido a seu tamanho de telas têm sido empregados para tarefas mais elementares e não profissionais.

Por outro lado, os aparelhos de computação móvel (Tablets), que surgiram logo em seguida aos smartphones, vêm se destacando para as tarefas mais complexas devido a sua maior capacidade computacional, telas maiores com melhor visualização do que está sendo trabalhado e pela capacidade de preenchimento de textos e planilhas mais facilmente, usando telas sensíveis ao toque (teclado integrado), oferecendo ainda massa ("peso") reduzido, boa ergometria e fácil manuseio, porém, se necessário, dispondo de teclado para emprego opcional (periférico).

Seu emprego profissional vêm se tornando comum em muitas áreas de trabalho (Patten, Sanchez e Tangney 2005), principalmente nos trabalhos de campo, porque eles se juntam às capacidades de servir como plataforma de coleta de dados (Guadagno et al, 2004) (digitalização da informação, fotografia e filmagem de ambientes e objetos) com a capacidade de análise e interpretação de informações (Righi e Celani, 2008) e, não esquecendo a capacidade de compartilhamento em tempo real de dados. 
Historicamente, os dispositivos móveis de computação (Tablets) já vêm sendo empregados largamente na área da saúde desde 2001, como informa Apkon e Singhaviranon para o arquivamento e verificação do fluxo de dados de pacientes e, no país desde 2011 segundo Crispin e Fernades no preenchimento de formulários e fichas médicas e realização na triagem inicial.

$\mathrm{Na}$ área educacional Almeida e Azevedo (2009) efetuaram estudos voltados para inserir "Tablets" no sentido de auxiliar estudantes na tarefa de aprendizado e analise.

Dlugosz et al. (2010), em uma parceria da EMBRAPA com o Exército Brasileiro, desenvolveram um moderno sistema de sensoriamento para estudar a cobertura vegetal brasileira que integrava a coleta de dados aero - fotográficos com dados de campo que eram coletados por "Tablets" com capacidade de geo-posicionamento por "GPS".

Enfatizando, os "Tablets" atualmente comercializados permitem:

$>$ Entrada de dados diretamente com 0 preenchimento de questionários usando telas sensíveis ao toque ao invés de teclados;

Obtenção direta das coordenadas geográficas (GPS);

$>$ Realização de fotografias e filmagem com resolução igual ou melhor que câmeras fotográficas com filmes a base de acetato (processo químico);

$>$ Arquivamento dos dados e a análise preliminar;

> Intercomunicação de dados em tempo real com a unidade central através da internet, e;

$>$ Comunicação de direta de voz. 
Independente do sistema operacional, todas essas características estão associadas ao desenvolvimento simples e rápido dos programas a serem utilizados.

Além disso, o uso crescente de "Tablets" é devido ao fato principal de seu custo ser relativamente baixo, ou seja, possuir uma boa relação custo/benefício, associado um desempenho apropriado.

\subsubsection{Dispositivos de computação móvel para a coleta de dados na área forense}

$\mathrm{Na}$ área forense, Baber et all (2006), com base na análise de casos, desenvolveram um protótipo de um dispositivo de computação móvel com a capacidade de coleta de informações e dados que mostrou maior eficácia e agilidade em comparação com os métodos convencionais e, complementarmente, os investigadores tais como Bulka, Pozdnyakov e Agarwal (2005) e Alves (2007) estudaram o uso de sensores presentes em pequenos dispositivos móveis (smartphones e tablets) para ser usado na coleta de dados biométricos, tais como impressões digitais.

Recentemente, Bennett (2012) descreveu de forma detalhada como processar a coleta e análise de evidências digitais e, citando o uso de programas comerciais existentes que podem ser empregados, apresentou alguns desafios para o uso de dispositivos móveis que podem surgir no uso ostensivo em campo, sugerindo assim, o desenvolvimento de programas especificos.

\subsection{MATERIAIS E METODOS}

Em consonância com as lacunas observadas no sistema policial brasileiro (item 1.4), a solução proposta (item 1.5), os parâmetros adotados (item 1.6), as etapas mínimas necessárias à realização dos exames periciais 
(item 2.2), a necessidade da execução de analises mais detalhadas das informações, vestígios e dados e a possibilidade de que os exames sejam acompanhados em tempo real, externamente por um supervisor, o sistema em desenvolvimento será dotado de:

1. Metodologia pericial integrada;

2. Estrutura física composta de unidades de computação movel e fixa;

3. Plataforma computacional aberta e flexível;

4. Conjunto de programas desenvolvidos especificamente para o sistema;

5. Conjunto de programas comerciais adquiridos, e;

6. Controle da cadeia de custódia.

\subsection{Metodologia pericial integrada}

A metodologia adotada compõem-se de cinco (5) fases dispostas na sequencia operacional da realização dos exames:

\section{1ํ Fase - Definicão do procedimento;}

$\mathrm{Na}$ qual o perito, após colher as informações iniciais e fazer um mapa mental da situação, escolhe o melhor procedimento pré-definido ${ }^{12}$ para a realização dos exames;

$2^{\circ}$ Fase - Coleta de informacõos administrativas, dados do local e identificacão dos vestígios;

Utilizando os equipamentos móveis em associação com seus sensores externos e internos os peritos coletarão as informações administrativas, informações verbais, vestígios e dados mesuráveis do local.

12 Com a adoção de procedimentos pré-definidos os exames adquirem um dos atributos científicos, ou seja, a garantia que possa ser realizado e examinado por outras pessoas e, em TESE, ter a(s) mesmas(s) conclusão(ões). 
$\mathrm{Na}$ sequência identificarão cada um dos dados conforme sua natureza e origem, ato contínuo obtendo suas coordenadas e enumerandoos ${ }^{13}$, um a um, consoante os vestígios presentes no local e relacionados com o(s) fato(s);

\section{Fase - Elaboracão das fotografias e croquis;}

Após, os policiais técnico-científicos utilizarão os "Tablets" para a obtenção da representação detalhada da situação e posição do local de delito e dos vestígios efetuando o desenho de croquis esquemático, fotografias panorâmicas, de média distância e com aproximação.

Porém, para a obtenção de fotos detalhadas de vestígios serão acopladas ao dispositivo móvel câmeras digitais de melhor resolução com conjuntos de lentes e filtros apropriados ${ }^{14}$;

\section{Fase - Coleta de vestígios e inicializacão da cadeia de} custódia;

Utilizando os programas desenvolvidos especificamente para a atividade pericial, em conjunto com os programas adquiridos, os peritos coletarão os vestígios encontrados de forma mais ági ${ }^{15}$ e eficiente, e inicializarão automaticamente a cadeia de custódia anotando os dados administrativos referentes aos vestígios, efetuando o arquivamento direto dos dados;

\footnotetext{
${ }^{13}$ Com a colocação de marcadores de fácil visualização.

${ }^{14}$ A escolha do conjunto de lentes é função principalmente da distância focal necessária para a visualização do detalhe

${ }^{15} \mathrm{Em}$ um tempo inferior aos efetuados atualmente
} 


\section{Fase - Avaliacão dos exames;}

Na técnica pericial atual ao finalizarem os exames de local os peritos (no próprio local de crime) efetuam uma avaliação preliminar e simplificada para se verificar se o objetivo dos exames foi alcançado verificando apenas se os vestígios encontrados foram coletados devidamente e, não efetuando qualquer análise da consistência, integridade, e relacionamento dos vestígios e informações coletados com a possível dinâmica do crime e dos possíveis atores.

No sistema em desenvolvimento, diferente das metodologias em uso ao redor do mundo, na avaliação dos exames os peritos e o supervisor remoto efetuarão uma análise preliminar dos vestígios, informações e dados, verificando o encadeamento lógico com a possível dinâmica e identificando os possíveis atores e, a integridade da cadeia de custódia.

Caso a verificação aponte que os objetivos não foram alcançados, haverá um alerta enviado a partir da unidade central para os peritos em campo (feed back), especificando a necessidade de complementação dos trabalhos, ou até mesmo, sua reinicialização. Desse modo os exames retroagiram àquela fase apontada e novos vestígios deverão ser procurados para sanar as lacunas encontradas.

Consoante à imediata análise dos dados, com adequada supervisão, a implementação deste feed back, até então inexistente, como se verifica no confronto com o fluxograma da figura 4 , representa importante inovação neste tipo e estudo.

O desenho esquemático a seguir apresenta a sequência das fases e subfases da metodologia e seus encadeamentos (laços). 


\section{MODELO PROPOSTO PELO TRABALHO}

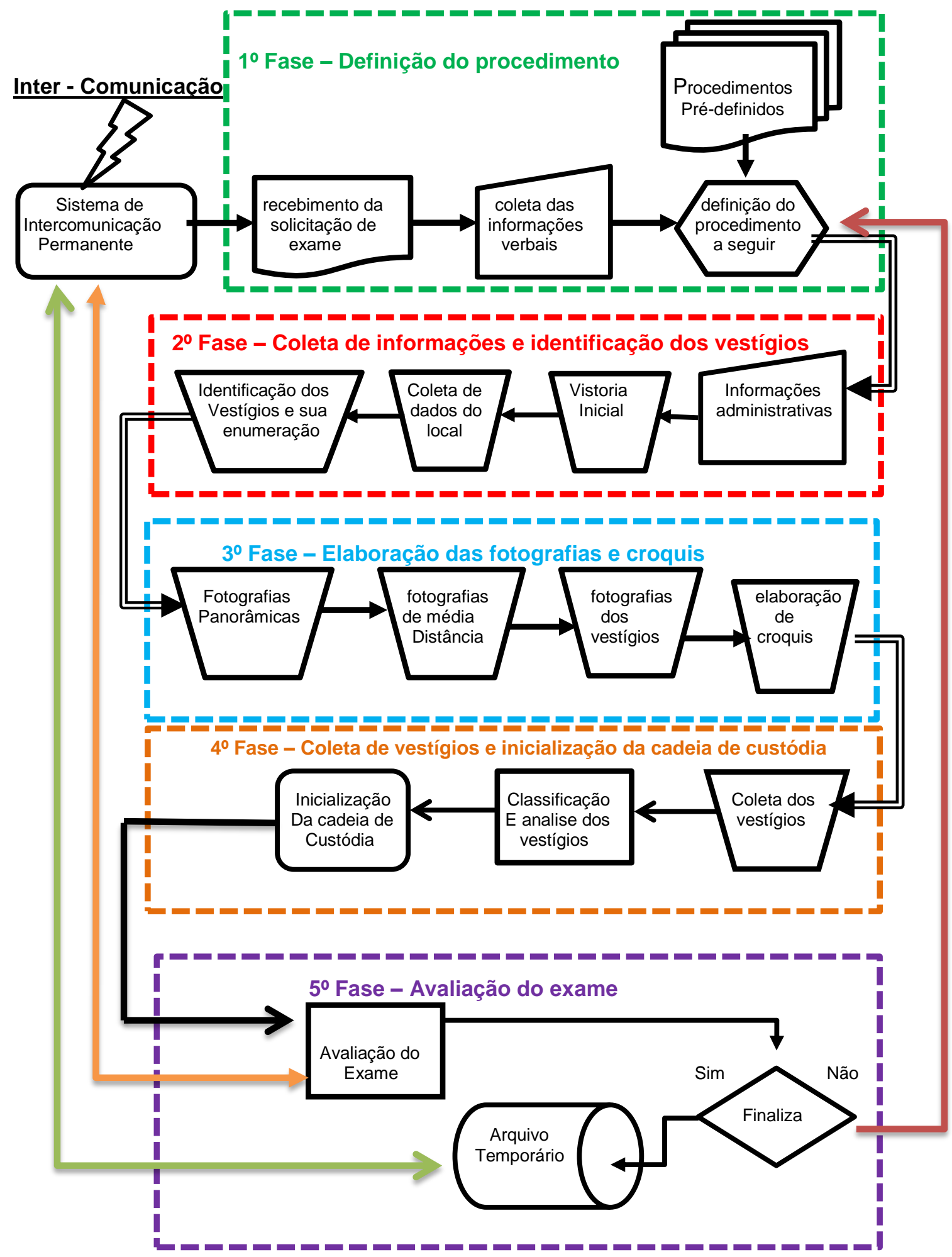

Figura $\mathbf{5}$ - Sequências de fases e subfases / encadeamentos 


\subsection{Estrutura fisica}

No sistema em desenvolvimento a estrutura física idealizada é constituída de:

1. Conjunto de dispositivos móveis computacionais (Tablets);

2. Sensores internos e externos conectados aos Tablets, e;

3. Unidade de processamento central "UPC" remota (Microcomputador fixo).

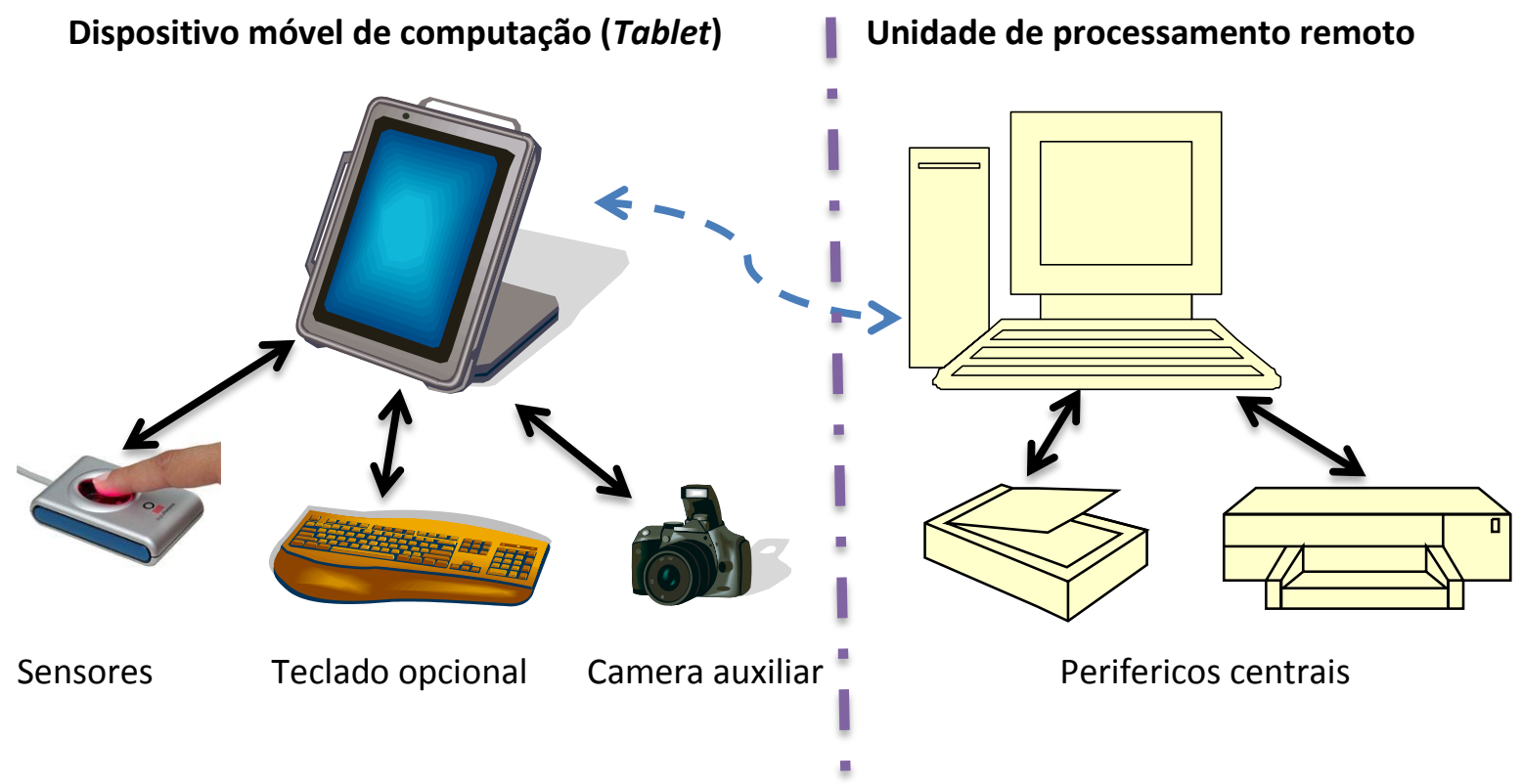

Figura 6. - Estrutura física do Sistema

\subsubsection{Dispositivos móveis computacionais (Tablets)}

Para o protótipo foi escolhido o "Tablet" da marca "Acer", modelo "Iconia A501" devido ao fato que:

Seu sistema operacional (Android 3.2) é aberto e livre. Permite carregar, executar e, caso necessário, alterar ainda na fase de protótipo, os programas elaborados especificamente para as atividades periciais, assim como empregar, provisoriamente, 
dentro de suas limitações práticas, os programas porventura adquiridos;

Sua câmera traseira, com cinco (5) megapixel de resolução, permite a execução de fotografias panorâmicas e com aproximação, ou seja, com funcionalidade semelhante (se não superior) ao das câmeras com filmes de rolo e revelação química, amplamente empregada até recentemente na ilustração das provas apresentadas ao judiciário;

> Seus sensores internos permitem a medição das grandezas físicas normalmente encontradas nos exames periciais, propiciando ainda a memorização de tais leituras e suas conversões diretas em dados (digitalização);

> Suas portas USB2 e mini-USB permitem a interligação com periféricos e sensores externos e a transferência dos dados armazenados;

Seu sistema de comunicação por telefonia sem fio com tecnologia "3G" possibilita a interligação com a unidade de processamento central (UPR) localizada na unidade de criminalística afeta ao local (central de perícia), através da rede de internet, permitindo, caso necessário, a troca de dados, analise e realização de videoconferência com mais de dois operadores do sistema;

Os dados coletados podem ser arquivados temporariamente em memórias de estado sólido de 64 GB (sessenta e quatro Gigabytes) e transferidos durante os exames 
ou posteriormente, caso haja a perda de comunicação, para a central remota.

\subsubsection{Sensores internos e externos interligados aos "Tablets"}

\subsubsection{Sensores internos.}

Os sensores internos originais dos dispositivos permitem respectivamente a medição das seguintes grandezas:

* Tela sensível ao toque - Pequenas dimensões lineares de comprimento, largura, área e ângulo;

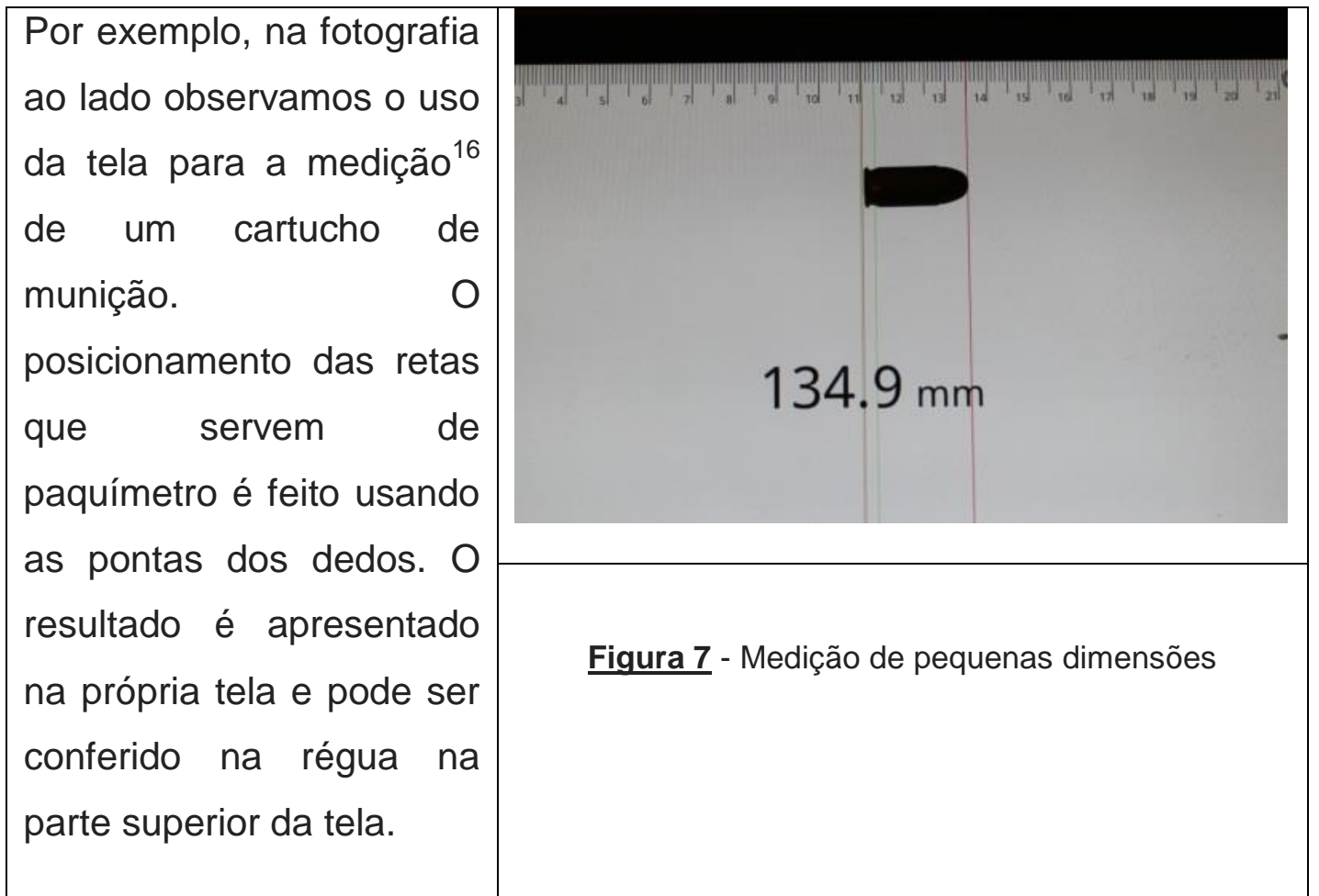

* Câmeras acopladas - As câmeras internas, além de possibilitarem a obtenção de fotografias e vídeos, podem ser utilizadas como sensores para a medição ${ }^{17}$ de distâncias, velocidades de objetos em relação ao referencial e, iluminação;

\footnotetext{
${ }^{16}$ Utilizando o modulo "Length" do programa "Smart tools"

${ }^{17}$ Utilizando o modulo "Distance" do programa "Smart tools".
} 
- Acelerômetros em três eixos - Acelerações lineares ${ }^{18}$ nos três eixos que podem ser utilizadas para a medição de vibrações veiculares e prediais;

* Giroscópio em três eixos - Utilizado para a medição de deslocamentos angulares ${ }^{19} \mathrm{em}$ relação à normal;

* Magnetômetro - Utilizado para a identificação das linhas de orientação de campos magnéticos, tais como o terrestre ${ }^{20}$, e detecção de metais;

* Microfone - Utilizado para o registro de sons e medição do nível da pressão acústica;

\subsubsection{Sensores externos}

Nos testes iniciais de campo do protótipo, foi acoplada ao Tablet através da porta USB uma câmera digital da marca Canon, modelo "EOS REBEL T3i" que utilizava:

Para as fotografias de detalhes (com aproximação), uma lente da marca Canon, modelo EFS 18-55, com auto estabilização;

Para as fotografias de impressões digitais, palmares e impressões de pneumáticos uma lente "Macro" da marca Canon, modelo "EF-S $60 \mathrm{~mm}$;

Flash da marca Canon, modelo "Speedlite 420EX" com cabos de extensão para a iluminação rasante e periférica;

> Dispositivo de iluminação pontual da marca GREIKA, modelo "RING 48", e;

$>$ Conjunto de filtros ópticos e lentes adicionais.

\footnotetext{
${ }^{18}$ Utilizando o modulo "Vibration" do programa "Smart tools"

${ }^{19}$ No caso pericial poderia, por exemplo, ser usado para a medição de inclinações de vias e edifícios.

${ }^{20}$ Utilizado em compassos e bússolas
} 


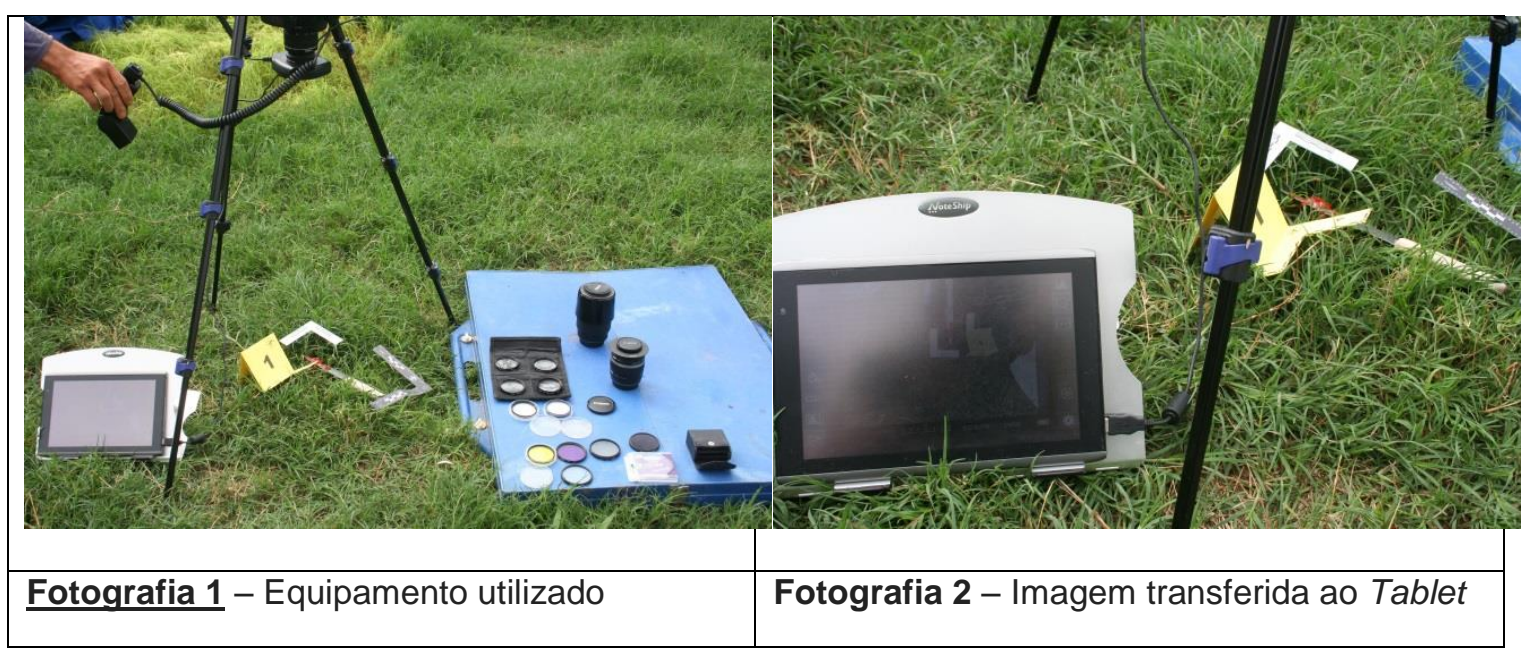

\subsubsection{Unidade Remota de Processamento}

Para o protótipo foi utilizado um microcomputador PC, modelo "Positivo 3D" conectado a rede de internet e uma impressora da marca "HP" modelo "Photosmart C4680" que dispunha de dispositivo de scanner acoplado.

\subsection{Plataforma computacional aberta}

Para que o sistema em desenvolvimento fosse flexível e possibilitasse que o perito seguisse o procedimento pericial definido optou-se pela criação de uma estrutura de programa controlador com rotinas dispostas em árvore hierarquizada, ou seja, o programa se constitui de um conjunto de rotinas independentes que podem ser chamadas segundo uma sequência definida, mas, com a possibilidade de alteração.

A rotina raiz (nível $\mathbf{0}$ ) controla a sequência de chamada das rotinas inferiores em conformidade com o procedimento definido, porém, se for detectado um vestígio ou informação (evidência) fora deste procedimento (inesperada), um outro procedimento pode ser chamado e adotado permanentemente, ou utilizado temporariamente até que o processamento da evidência seja finalizado e retorne ao procedimento original. 


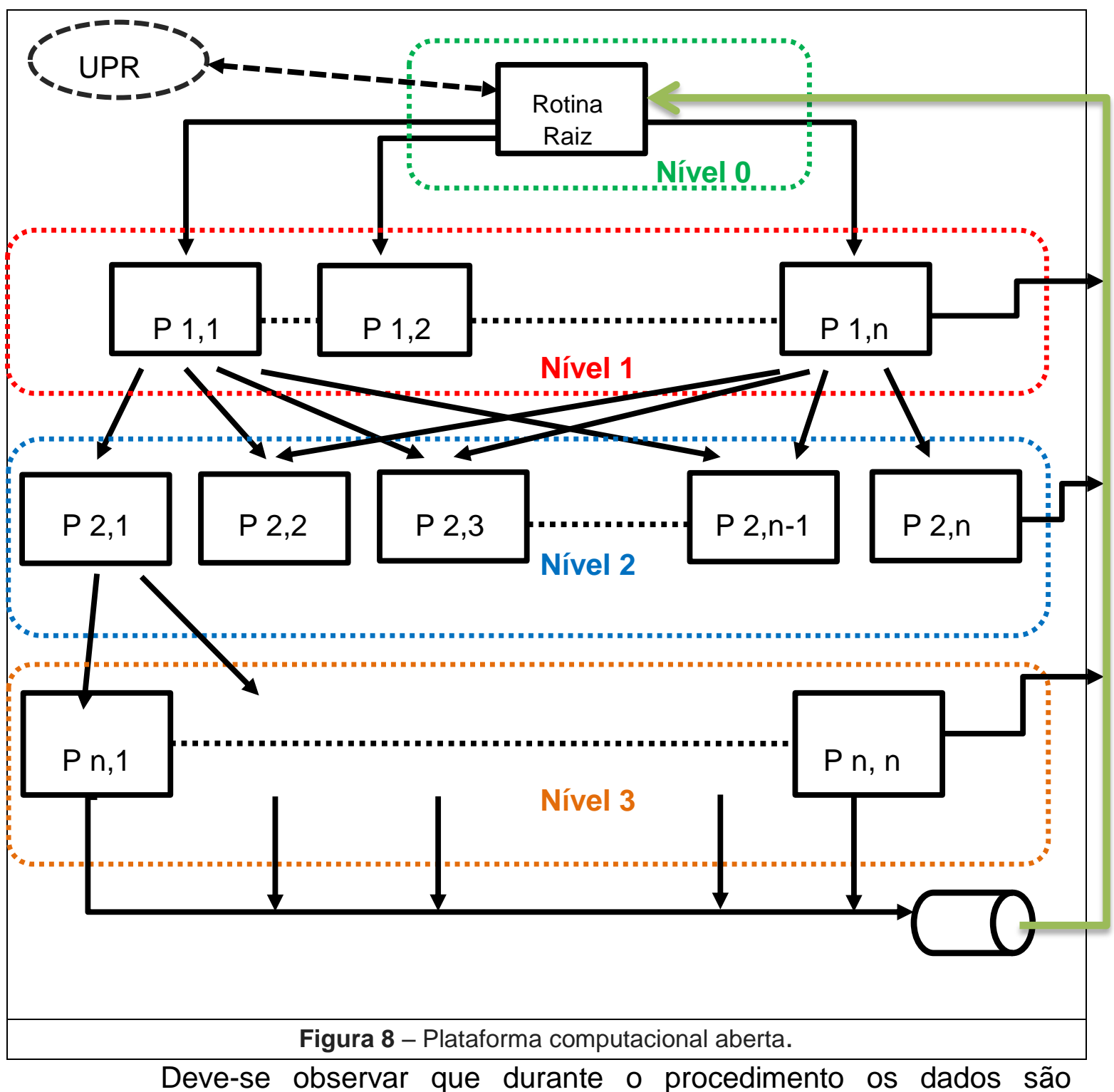

arquivados internamente e temporariamente, podendo ser processados (analisados) inicialmente no próprio dispositivo, porém, a rotina raiz que tem também a função de controlar as comunicações, os envia periodicamente a central remota para processamento paralelo. Salienta-se que na elaboração das rotinas foram utilizados os "comandos" preexistentes do sistema operacional.

Por exemplo, para a obtenção de uma fotografia de média resolução o programa chama o aplicativo de fotografia presente originalmente no dispositivo e, para a troca de dados, utiliza rotinas internas do dispositivo elaboradas em Java, consideando-se que há algumas particularidades dos próprios dispositivos e que variam bastante de acordo com cada modelo e fabricante. 


\subsection{Conjunto de programas desenvolvidos especificamente para o sistema}

Para o protótipo do sistema as rotinas foram desenvolvidas para cobrir o crime de furto seguindo o procedimento estabelecido por Fonseca, Merege e Sanches (aguardando publicação) que esta em conformidade com a metodologia descrita no item 3.1.

Este procedimento, para realizar um detalhamento mais aprofundado, inclusive observando caracteristicas sociais e operacionais do agente delituoso, incluem um número muito maior de variáveis que as coletadas nos procedimentos convencionais.

\begin{tabular}{|c|c|c|c|c|c|}
\hline & Rotina & $\begin{array}{l}\text { Procedin } \\
\text { Convenc }\end{array}$ & $\begin{array}{l}\text { iento } \\
\text { ional }\end{array}$ & $\begin{array}{r}\text { Proced } \\
\text { do pro }\end{array}$ & $\begin{array}{l}\text { nento } \\
\text { stipo }\end{array}$ \\
\hline Tela & Título & Informes & dados & Informes & dados \\
\hline 0.0 & Tela inicial & - & - & - & - \\
\hline 1.0 & Formulários & - & - & - & - \\
\hline 1.1 & Dados administrativos & 0 & 12 & 0 & 14 \\
\hline 1.2 & Caracteristicas da vítima & 0 & 5 & 0 & 12 \\
\hline 1.3 & Meio de acesso ao interior do terreno & 0 & 6 & 0 & 8 \\
\hline 1.4 & Meio de acesso a coisa & 0 & 6 & 0 & 37 \\
\hline 1.5 & Caracteristicas da coisa & 0 & $\mathrm{C}^{21}$ & 0 & $8 \times C$ \\
\hline & Feição dos suspeitos ${ }^{22}$ & 0 & 0 & 1 & 0 \\
\hline & Dimensões dos vestígios ${ }^{23}$ & 0 & 0 & 0 & $\mathrm{n}^{24}$ \\
\hline
\end{tabular}

\footnotetext{
${ }^{21} \mathrm{C}$ é o número de coisas furtadas

${ }^{22}$ Utilizando o programa "Flash Face"

${ }^{23}$ Utilizando o programa "Smart Tools"

${ }^{24}$ O número " $\mathrm{n}$ " é proporcional ao número de vestígios e dimensões a serem medidos
} 
Para o registro das informações introduzidas nos dispositivos móveis foi necessário o desenvolvimento exclusívo de um aplicativo móvel híbrido denominado SPCR (Sistema de Pericia Criminal e Relatórios - sigla adotada pelo pesquisador).

Este aplicativo híbrido foi desenvolvido utilizando-se das linguagens HTML5, JavaScript e CSS3 e contém um navegador embutido para renderização da interface do aplicativo bem como execução das suas funcionalidades, permitindo ainda 0 acesso aos recursos porventura disponíveis no dispositivo, tais como câmera, GPS, lista de contatos, entre outros.

Desse modo obteve-se a vantagem de permitir menor tempo na construção de soluções para plataformas diferentes utilizando o mesmo código fonte, o que possibilita sua disponibilização para plataformas como Android, iOs e Windows Mobile em um prazo muito menor do que aquele para se desenvolver três aplicativos distintos para cada plataforma. Após 0 desenvolvimento o sistema foi encapsulado em uma Webview que permite sua instalação e execução em cada dispositivo independentemente do sistema operacional.

O SPCR permite registrar no dispositivo móvel, as informações coletadas pelo perito em campo. Para isso o perito utiliza uma série de formulários previamante criados e disponíveis no SPCR, que consistem de campos de texto, múltipla escolha, data e fotos.

Tais formulários (ou planilhas) foram criados a partir do tirocínio do pesquisador em somatório com extenso estudo acerca do tipo de crime elegido para o presente trabalho (crime de furto - artigo 155 do Código Prenal).

O aplicativo apresenta ainda os recursos:

- Escaneamento de códigos binários impressos (QRCode) que tenham sido previamente codificados de forma a conter informações necessárias para completar os formulários do sistema; 
> Geolocalização (quando disponível e habilitado no dispositivo) que permite registrar a longitude e a latitude referentes ao local onde o perito esteja trabalhando no momento do registro das informações. Os dados são armazenados no banco de dados local do dispositivo, o SQLite, um banco de dados relacional otimizado para dispositivos móveis, que permite grande compatibilidade com os principais SGBD's disponíveis no mercado no que diz respeito ao formato de armazenamento e ao acesso aos dados;

- Tela para desenho, permitindo agilizar a ilustração da cena do delito sob exame, com gráficos vetoriais pré-configurados. Estes gráficos podem ser inseridos na tela de desenho e manipulados através de controles tais como: altura, largura, rotação, posição x,y, etc. Cada gráfico inserido na tela de desenho pode ser identificado com uma etiqueta e podem ser 'arrastados' com movimentos de toque na tela do dispositivo;

- Capacidade de transmitir os dados, quando conectado à Internet, seja através de uma rede sem fio (Wi-FI) ou serviço de dados da operadora de telefonia móvel (2G/3G/4G). Na transmissão os dados são lidos do banco de dados local e formatados em JSON (JavaScript Object Notation) e transmitidos para um servidor que pode estar localizado na rede local ou na nuvem. Dados e informações também podem ser recebidos do servidor para orientar o perito na condução do trabalho de campo.

O SPCR foi desenvolvido utilizando tecnologias e/ou bibliotecas tais como: Jquery 1.9.1, Jquery Mobile 1.3.2, Jquery Knob, Jquery Transit, Draggabilly, Font Awesome (ícones vetorizados), HTML5, CSS3. 


\subsubsection{Tablets}

Para os "Tablets" utilizados no protótipo as rotinas foram desenvolvidas utilizando-se a linguagem Android versão 3.2 (API 13).

A entrada de informações e dados foi "escrita" na forma de FORMULÁRIOS, em que as entradas, logicamente encadeadas, e que descrevem o local e o fato criminoso, estão designados por variaveis dispostas na sequência dos exames e são apresentadas no anexo $\mathrm{n}^{0} 1 \mathrm{e}$, as rotinas na linguagem Java são apresentadas no anexo $n^{\circ}$ 2. Os formularios dispõem de campos de preenchimento e questões de multipla escolha.

\begin{tabular}{|l}
$\begin{array}{l}\text { No exemplo apresentado ao lado os } \\
\text { campos de: }\end{array}$ \\
Bo (numero do boletim de \\
ocorrência); \\
DP (Delegacia requisitante); \\
- Endereço do local, \\
- Nome das testemunhas ou \\
vitimas;
\end{tabular}


Para a coleta de dados que são descritos em dois estados, tais como: "Preservação do local do crime", as rotinas dispõem de botões virtuais já ativados com o estado de maior frequencia, que é apresentado como "default".

\section{@im o Não}

Tal medida propicia maior comodidade no carregamento dos dados, remetendo ao encadeamento lógico quando da operação do dispositivo.

Adicionalmente, durante a execução das rotinas os peritos podem acionar através da tela sensível ao toque os sensores internos (câmeras, microfones, etc.) e os sensores conectados.

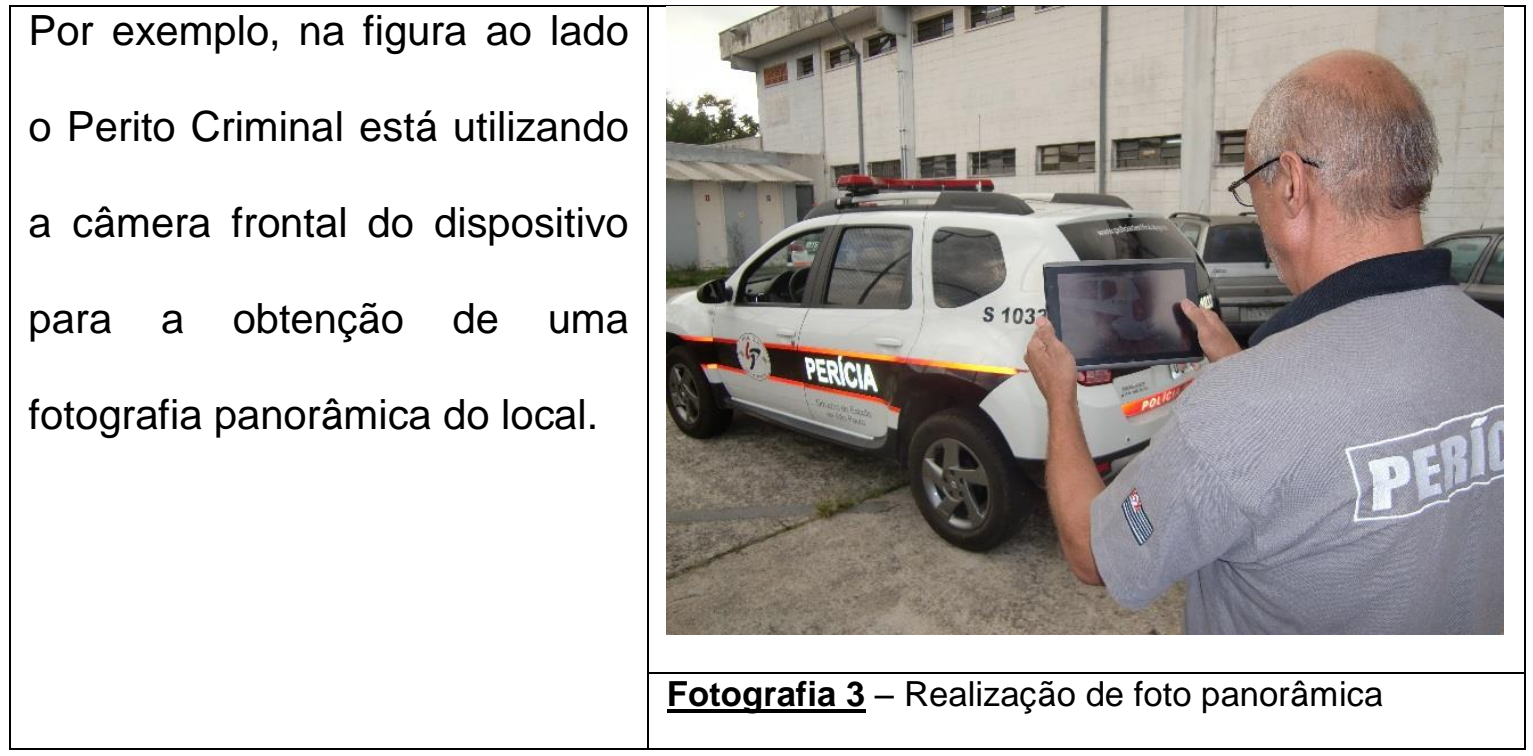

\subsubsection{Unidade de Processamento Central}

Para a unidade central atuar na análise dos dados e informações foi desenvolvido um programa utilizando-se do "Matlab", empregando conhecimentos sobre redes neurais, trabalho este concluído na tese de Fernando Merege (2014). 


\subsection{Conjuntos de programas comerciais}

\subsubsection{Fotos de alta resolução}

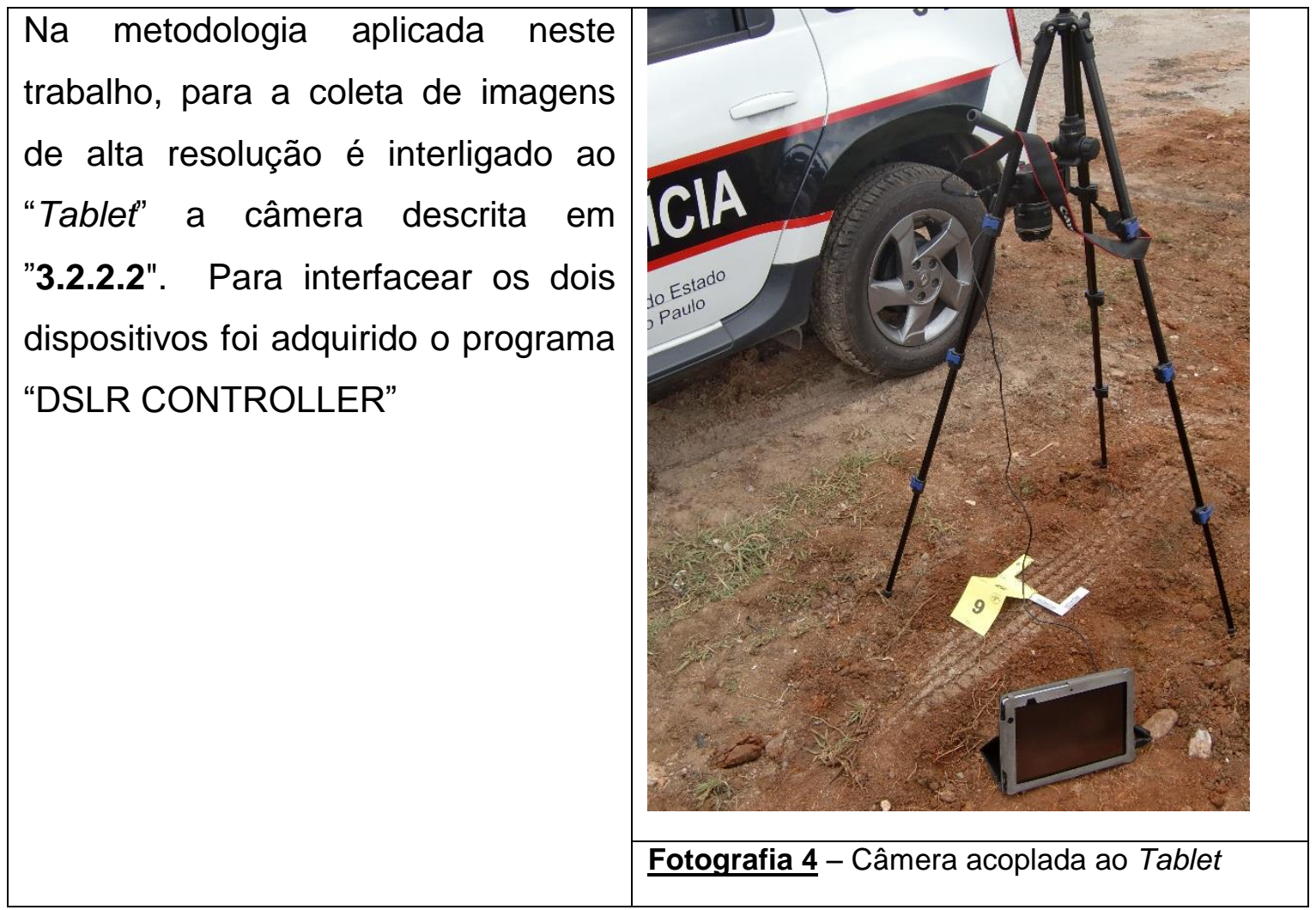

O aplicativo permite, durante o exame, a visualização da imagem ${ }^{25}$ na tela do tablet e a realização de ajustes diretamente na câmera, tais como: abertura, tempo de exposição, ISO e outro.

\subsubsection{Elaboração de croquis.}

Até a presente data, não foi encontrado uma aplicativo comercial para a realização de croquis de local de crime compativel com as necessidades da perícia criminal. Os programas encontrados foram desenvolvidos para uso

\footnotetext{
${ }^{25}$ Para a realização de fotos de alta resolução é convencionado o uso do modo RAW com 20 Mega Pixels
} 
civil podendo ser adaptado para outros usos, porém, não possuem a flexibilidade e capacidade necessárias.

\subsubsection{Esboço de rostos.}

Um exemplo de programa comercial
elaborado para uso civil e facilmente
empregado na área forense é o
aplicativo "flashface", que permite
desenhar rostos de homens e mulheres.
Projetado para ser interativo e intuitivo
pode ser usado por desenhistas não
especialistas para fazer esboços de
suspeitos no local de crime com
facilidade.
Durante a coleta de informações das
testemunhas é possivel elaborar o
esboço da face do agressor.
No aplicativo, você pode escolher entre
as opções do menu as características
faciais que você quer adicionar,
posicionado-as e alterar as dimensões
das características escolhidas.

\subsubsection{Aplicativo para a medição de grandezas físicas.}

A aplicação comercial do programa Smart Tools facilmente encontrados na internet, por exemplo, possui vários módulos que podem ser utilizados em trabalhos forenses no campo. 
Usando o módulo "Length" podemos realizar medições de pequenos objetos com uma precisão de milímetros, inicialmente suficientes para este tipo de exame.

A Figura 8 em "3.2.2.1" ilustra mostra a medição de um estojo de munição de arma de fogo com emprego desse aplicativo, onde é possível a medição de pequenos objetos.

\subsection{RESULTADOS OBTIDOS}

\subsection{Exames com o protótipo}

Entre novembro de 2012 e julho de 2013, na cidade de São Bernardo do Campo, São Paulo, Brasil, utilizando-se o protótipo, foram realizados testes de campo exclusivamente para os módulos relacionados com o crime de "furto".

Os exames se realizaram com o apoio dos mesmos quatro peritos criminais que participaram dos exames descritos no item "1.4.2"

Exceto o perito criminal mais experiente, que foi um dos idealizadores do sistema, os demais peritos receberam um treinamento na operação do protótipo de aproximadamente uma hora.

Os peritos (com suas equipes) foram acompanhados por períodos de doze (12) horas em dias diferentes da semana e, apenas nos casos de "furto". Os tempos gastos nos exames foram cronometrados a partir do momento da chegada ao local examinado até a finalização do procedimento de campo.

No total foi acompanhada a realização de sessenta e seis (66) exames em locais de furto. 


\subsection{Considerações iniciais}

a) Os exames não foram realizados "on-line", ou seja, as equipes não foram acompanhadas remotamente;

b) Enquanto os peritos manuseavam o protótipo os Fotógrafos Técnico-periciais efetuavam as anotações dos trabalhos ${ }^{26}$ executados seguindo o método comumente empregado por cada perito;

c) As fotografias de detalhes (impressões digitais, pegadas, etc.) foram efetuadas nos dois modos (modo convencional com câmera independente manuseada pelo Fotógrafo Técnicopericial e no modo do sistema com câmera acoplada manuseada pelo perito);

d) Só foi considerado o tempo gasto que foi contado em minutos e quartos de minuto (15 segundos) completados devido ao fato que uma precisão maior (segundos) não teria representatividade;

e) As informações e dados coletados foram transferidos a unidade remota de computação ao final de cada plantão;

f) As etiquetas com código de barras que foram impressas antecipadamente aos exames receberam os números dos lacres designados a cada perito;

g) Os peritos tiveram acesso ao computador remoto para efetuar a impressão dos laudos através das funções "macro" do aplicativo editor de texto, porém, os laudos definitivos (em papel) foram elaborados pelos métodos de cada perito, de modo a não interferir no desenrolar do expediente daquele órgão público;

${ }^{26} \mathrm{Em}$ alguns momentos os peritos efetuavam uma pausa no uso do protótipo para ditar instruções aos Fotógrafos Técnico-periciais 


\subsection{Verificação do desempenho do protótipo}

No final do período de testes os peritos preencheram um questionário com as seguintes questões:

1. A ergometria do dispositivo era adequada para o uso em campo? Explique?

2. A sequência das telas era adequada para a realização dos exames? Explique?

3. Nos questionários apresentados o tamanho das letras era satisfatório para a realização da leitura rápida? Explique?

4. O uso do teclado virtual (tela sensível) era adequado para o preenchimento dos formulários? Explique?

5. O uso da câmera do dispositivo era adequada para a realização de fotografias panorâmicas? Explique?

6. O uso da câmera do dispositivo era adequada para a realização de fotografias de média distância? Explique?

7. O uso da câmera externa acoplada ao dispositivo era adequado para a realização de fotografias de detalhes? Explique?

8. O programa (adquirido) de medição de grandezas físicas era adequado? Explique?

9. O programa (adquirido) de elaboração de croquis de feições dos suspeitos era adequado? Explique?

10. 0 programa (adquirido) de leitura de código de barras era adequado? Explique?

11. A macro utilizada na elaboração dos laudos era adequada? Explique?

12. O treinamento efetuado foi adequado? Explique?

13. Efetue sugestões para a melhora do sistema?

Exceto para a última questão foram atribuídos os seguintes pesos às respostas: 


\begin{tabular}{|l|l|}
\hline Não opinou & 0 \\
\hline Inadequado & 1 \\
\hline Adequado com ressalvas & 2 \\
\hline Adequado & 3 \\
\hline
\end{tabular}

Tabela 5 - Lista de valoração dos quesitos

\subsection{Resultados dos exames}

1) O perito número um (1) realizou doze exames e, devido ao fato de ter participado no desenvolvimento do sistema, não preencheu 0 questionário de avaliação e não opinou.

Obteve os seguintes resultados:

\begin{tabular}{|l|l|l|l|}
\hline № & $\begin{array}{l}\text { Tipo do } \\
\text { Local }\end{array}$ & Evidências coletadas & $\begin{array}{l}\text { Tempo } \\
\text { (min) }\end{array}$ \\
\hline 1 & Residência & 0 & 12,25 \\
\hline 2 & Residência & $\begin{array}{l}\text { Uma (01) fotografia de impressão } \\
\text { digital }\end{array}$ & 20,5 \\
\hline 3 & Escola Pública & $\begin{array}{l}\text { Uma (01) fotografia de pegada (no } \\
\text { muro decorrente de escalada) }\end{array}$ & 21,25 \\
\hline 4 & Residência & 0 & 12,00 \\
\hline 5 & Escola Pública & 0 & 18,00 \\
\hline 6 & Residência & $\begin{array}{l}\text { Uma (01) fotografia de impressão } \\
\text { digital }\end{array}$ & 25,00 \\
\hline 7 & Residência & 0 & 13,25 \\
\hline 8 & Residência & 0 & 12,50 \\
\hline 9 & Fabrica & 0 & 15,00 \\
\hline 10 & Residência & 0 & 12,50 \\
\hline
\end{tabular}




\begin{tabular}{|r|l|l|l|}
\hline 11 & Escritório & 0 & 14,00 \\
\hline 12 & Escola Pública & $\begin{array}{l}\text { Uma (01) fotografia de pegada (no } \\
\text { muro decorrente de escalada) }\end{array}$ & 22,00 \\
\hline \multicolumn{2}{|r|}{ Média } & $\mathbf{1 6 , 5 0}$ \\
\hline
\end{tabular}

Tabela $\mathbf{6}$ - Anotação da coleta de evidências nos locais versus tempo necessário (Perito (1))

O tempo médio foi de dezesseis minutos e meio, porém, deve-se observar que apenas em quatro (4) casos foi efetuada a fotografia dos vestígios.

Devido ao fato de se encontrarem "prejudicadas" as evidências físicas não foram coletadas.

2) $O$ segundo (2) perito realizou vinte e dois (22) exames:

\begin{tabular}{|c|c|c|c|}
\hline № & $\begin{array}{c}\text { Tipo do } \\
\text { Local }\end{array}$ & Evidências coletadas & $\begin{array}{c}\text { Tempo } \\
\text { (min) }\end{array}$ \\
\hline 1 & Residência & 0 & 16,00 \\
\hline 2 & Residência & Uma (01) fotografia de impressão & 19,50 \\
\hline 3 & Escrital & 15,75 \\
\hline 4 & $\begin{array}{c}\text { Oficina mecânica } \\
\text { (furto de fios de } \\
\text { cobre) }\end{array}$ & Uma (1) fotografia palmar & 17,50 \\
\hline 6 & Residência & $\begin{array}{c}\text { Colhido fisicamente três (3) } \\
\text { impressões digitais e uma (1) marca } \\
\text { de ferramenta }\end{array}$ & 29,00 \\
\hline 7 & Escola Pública & Uma (01) fotografia de pegada (no & 10,00 \\
\hline 8 & Residência & muro decorrente de escalada) & 16,25 \\
\hline 9 & $\begin{array}{c}\text { Fabrica } \\
\text { abandonada }\end{array}$ & $\begin{array}{c}\text { Uma (1) fotografia de pegada e uma } \\
\text { (1) fotografia de marca de pneumático }\end{array}$ & 24,50 \\
\hline 10 & Residência & 0 & 14,75 \\
\hline 11 & Escritório & 0 & 11,50 \\
\hline
\end{tabular}




\begin{tabular}{|c|c|c|c|}
\hline 12 & Residência & $\begin{array}{l}\text { Uma (1) fotografia de marca de } \\
\text { ferramenta }\end{array}$ & 22,00 \\
\hline 13 & Residência & 0 & 15,75 \\
\hline 14 & Escritório & 0 & 14,00 \\
\hline 15 & Residência & $\begin{array}{c}\text { Uma (01) fotografia de impressão } \\
\text { digital }\end{array}$ & 22,00 \\
\hline 16 & Escola Pública & 0 & 12,25 \\
\hline 17 & Residência & 0 & 15,00 \\
\hline 18 & Residência & 0 & 14,75 \\
\hline 19 & Residência & 0 & 15,25 \\
\hline 20 & $\begin{array}{c}\text { Poste elétrico } \\
\text { (furto de fios de } \\
\text { cobre) }\end{array}$ & 0 & 11,00 \\
\hline 21 & Escola Pública & $\begin{array}{l}\text { Uma (01) fotografia de pegada (no } \\
\text { muro decorrente de escalada) }\end{array}$ & 17,25 \\
\hline 22 & Escola Pública & $\begin{array}{c}\text { Uma (01) fotografia de pegada (no } \\
\text { muro decorrente de escalada) }\end{array}$ & 16,75 \\
\hline & & Média & 16,625 \\
\hline
\end{tabular}

O tempo médio foi de dezesseis minutos e seiscentos e vinte e cinco milésimos (16,625 minutos).

\section{Questionário (Perito 2):}

\begin{tabular}{|c|c|c|}
\hline № & & DESCRITIVO \\
\hline \multirow[b]{2}{*}{1} & \multicolumn{2}{|c|}{ A ergometria do dispositivo era adequada para o uso em campo? Explique? } \\
\hline & Adequado $=3$ & $\begin{array}{l}\text { O dispositivo foi de fácil manuseio e não prejudicou a } \\
\text { realização dos exames. }\end{array}$ \\
\hline 2 & \multicolumn{2}{|c|}{ A sequência das telas era adequada para a realização dos exames? Explique? } \\
\hline
\end{tabular}




\begin{tabular}{|c|c|c|}
\hline & $\begin{array}{l}\text { Adequado } \text { com } \\
\text { ressalvas }=2\end{array}$ & $\begin{array}{l}\text { Para a realização de certos tópicos deveria ser aberto uma } \\
\text { nova tela. }\end{array}$ \\
\hline \multirow{2}{*}{3} & \multicolumn{2}{|c|}{$\begin{array}{l}\text { Nos questionários apresentados o tamanho das letras era satisfatório para a } \\
\text { realização da leitura rápida? Explique? }\end{array}$} \\
\hline & Inadequado $=1$ & $\begin{array}{l}\text { As palavras estavam muito pequenas, assim as letras deveriam } \\
\text { ser maiores. Pelo menos o dobro do tamanho da fonte usado. }\end{array}$ \\
\hline \multirow{2}{*}{4} & \multicolumn{2}{|c|}{$\begin{array}{l}\text { O uso do teclado virtual (tela sensível) era adequado para o preenchimento dos } \\
\text { formulários? Explique? }\end{array}$} \\
\hline & $\begin{array}{l}\text { Adequado } \text { com } \\
\text { ressalvas }=2\end{array}$ & $\begin{array}{l}\text { Talvez devido a estar acostumado a usar teclados físicos o uso } \\
\text { do teclado virtual causou estranheza no início }\end{array}$ \\
\hline \multirow[b]{2}{*}{5} & \multicolumn{2}{|c|}{$\begin{array}{l}\text { O uso da câmera do dispositivo era adequado para a realização de fotografias } \\
\text { panorâmicas? Explique? }\end{array}$} \\
\hline & $\begin{array}{l}\text { Adequado com } \\
\text { ressalvas }=2\end{array}$ & $\begin{array}{l}\text { A realização das fotografias de detalhes foi muito pratica, pois, } \\
\text { foram efetuadas na sequência dos exames e não causaram } \\
\text { interrupções, porém, a falta de "zoom" não permitiu o melhor } \\
\text { enquadramento }\end{array}$ \\
\hline \multirow{2}{*}{6} & \multicolumn{2}{|c|}{$\begin{array}{l}\text { O uso da câmera do dispositivo era adequado para a realização de fotografias de } \\
\text { média distância? Explique? }\end{array}$} \\
\hline & $\begin{array}{l}\text { Adequado } \text { com } \\
\text { ressalvas }=2\end{array}$ & Idem ao anterior \\
\hline \multirow[b]{2}{*}{7} & \multicolumn{2}{|c|}{$\begin{array}{l}\text { O uso da câmera externa acoplada ao dispositivo era adequado para a realização } \\
\text { de fotografias de detalhes? Explique? }\end{array}$} \\
\hline & Adequado $=3$ & $\begin{array}{l}\text { O uso do tablet permite se efetuar uma boa visualização } \\
\text { dessas fotografias para saberem se tem condições de serem } \\
\text { analisadas posteriormente. }\end{array}$ \\
\hline 8 & \multicolumn{2}{|c|}{$\begin{array}{l}\text { O programa (adquirido) de medição de grandezas físicas era adequado? } \\
\text { Explique? }\end{array}$} \\
\hline & Não opinou $=0$ & Não foi utilizado \\
\hline 9 & \multicolumn{2}{|c|}{ O programa (adquirido) de elaboração de croquis de feições dos suspeitos era } \\
\hline
\end{tabular}




\begin{tabular}{|c|c|c|}
\hline & \multicolumn{2}{|c|}{ adequado? Explique? } \\
\hline & Não opinou $=0$ & Não foi utilizado \\
\hline \multirow[b]{2}{*}{10} & \multicolumn{2}{|c|}{ O programa (adquirido) de leitura de código de barras era adequado? Explique? } \\
\hline & $\begin{array}{l}\text { Adequado com } \\
\text { ressalvas }=2\end{array}$ & $\begin{array}{l}\text { Em vez de usarmos um questionário impresso para efetuar o } \\
\text { controle das peças coletadas deveria haver um modulo no } \\
\text { programa e os números dos códigos de barras passados } \\
\text { automaticamente }\end{array}$ \\
\hline \multirow{2}{*}{11} & \multicolumn{2}{|c|}{$\begin{array}{l}\text { A função macro do editor de texto, utilizada na elaboração dos laudos era } \\
\text { adequada? Explique? }\end{array}$} \\
\hline & $\begin{array}{l}\text { Adequado } \text { com } \\
\text { ressalvas }=2\end{array}$ & O relatório final ficou muito extenso. \\
\hline \multirow[b]{2}{*}{12} & \multicolumn{2}{|c|}{ O treinamento efetuado foi adequado? Explique? } \\
\hline & $\begin{array}{l}\text { Adequado com } \\
\text { ressalvas }=2\end{array}$ & $\begin{array}{l}\text { Deveria ser mais detalhado, explicando os motivos das } \\
\text { escolhas das subfases. }\end{array}$ \\
\hline \multirow[b]{2}{*}{13} & \multicolumn{2}{|c|}{ Efetue sugestões para a melhora do sistema. } \\
\hline & $\begin{array}{l}\text { Adequado com } \\
\text { ressalvas }=2\end{array}$ & Criar mais telas para melhor dividir as tarefas. \\
\hline
\end{tabular}

Tabela 8 - Repostas ao questionário sobre a coleta de evidências nos locais de exame (Perito (2))

Para este entrevistado o sistema recebeu vinte e três (23) pontos com duas questões não preenchidas devido ao não uso do recurso. Excluindo os itens não avaliados o sistema recebeu a pontuação média de dois pontos e nove décimos $(2,09)$, ou seja, é adequado com ressalvas.

3) O terceiro perito realizou dezesseis (16) exames: 


\begin{tabular}{|c|c|c|c|}
\hline № & $\begin{array}{l}\text { Tipo do } \\
\text { Local }\end{array}$ & Evidências coletadas & $\begin{array}{l}\text { Tempo } \\
\text { (min) }\end{array}$ \\
\hline 1 & Residência & $\begin{array}{c}\text { Uma (01) fotografia de impressão } \\
\text { digital }\end{array}$ & 16 \\
\hline 2 & Residência & 0 & 13.5 \\
\hline 3 & Residência & 0 & 15.75 \\
\hline 4 & Residência & 0 & 14 \\
\hline 5 & Escola Pública & Uma (1) fotografia palmar & 17.25 \\
\hline 6 & Residência & $\begin{array}{l}\text { Colhido e fotografado duas (2) } \\
\text { impressões digitais }\end{array}$ & 24.75 \\
\hline 7 & $\begin{array}{l}\text { Poste elétrico } \\
\text { (furto de fios de } \\
\text { cobre) }\end{array}$ & 0 & 10.25 \\
\hline 8 & Residência & 0 & 14 \\
\hline 9 & Oficina mecânica & $\begin{array}{l}\text { Colhido e fotografado uma (1) } \\
\text { impressão de pneumático }\end{array}$ & 28 \\
\hline 10 & Residência & $\begin{array}{l}\text { Coletado uma ferramenta utilizada (um } \\
\text { pé de cabra) }\end{array}$ & 15.50 \\
\hline 11 & Escritório contábil & 0 & 11.50 \\
\hline 12 & Residência & $\begin{array}{l}\text { Efetuado uma (1) fotografia de marca } \\
\text { de ferramenta e efetuado um esboço } \\
\text { de feição de suspeito (masculino) }\end{array}$ & 16 \\
\hline 13 & Residência & 0 & 15.75 \\
\hline 14 & Escola & 0 & 14 \\
\hline 15 & Residência & 0 & 12.50 \\
\hline 16 & Escola Pública & 0 & 12.25 \\
\hline & & Média & 15,650 \\
\hline
\end{tabular}

Tabela 9 - Anotação da coleta de evidências nos locais versus tempo necessário (Perito (3))

O tempo médio foi de quinze minutos e seiscentos e cincoenta milésimos (15,650 minutos). 


\section{Questionário (Perito 3):}

\begin{tabular}{|c|c|c|}
\hline № & & DESCRITIVO \\
\hline \multirow[b]{2}{*}{1} & \multicolumn{2}{|c|}{ A ergometria do dispositivo era adequada para o uso em campo? Explique? } \\
\hline & Adequado $=3$ & $\begin{array}{l}\text { O tablet é mais facilmente utilizável em campo que a prancheta } \\
\text { com folhas de papel, pois, não necessita manter uma mão } \\
\text { segurando um lápis (ou caneta) e a permite a complementação } \\
\text { das informações durante os exames. }\end{array}$ \\
\hline \multirow[b]{2}{*}{2} & \multicolumn{2}{|c|}{ A sequência das telas era adequada para a realização dos exames? Explique? } \\
\hline & Adequado $=3$ & $\begin{array}{l}\text { É um passo à frente, pois, o fluxo das telas presentes no } \\
\text { sistema permite a coleta de mais informações e dados que o } \\
\text { método atual. }\end{array}$ \\
\hline \multirow{2}{*}{3} & \multicolumn{2}{|c|}{$\begin{array}{l}\text { Nos questionários apresentados o tamanho das letras era satisfatório para a } \\
\text { realização da leitura rápida? Explique? }\end{array}$} \\
\hline & $\begin{array}{l}\text { Adequado } \text { com } \\
\text { ressalvas }=2\end{array}$ & $\begin{array}{l}\text { Pode ser usado, porém, para facilitar a visualização deveria ser } \\
\text { pelo o dobro do tamanho }\end{array}$ \\
\hline \multirow[t]{2}{*}{4} & \multicolumn{2}{|c|}{$\begin{array}{l}\text { O uso do teclado virtual (tela sensível) era adequado para o preenchimento dos } \\
\text { formulários? Explique? }\end{array}$} \\
\hline & Adequado $=3$ & Sim, pois é muito fácil utiliza-lo \\
\hline \multirow{2}{*}{5} & \multicolumn{2}{|c|}{$\begin{array}{l}\text { O uso da câmera do dispositivo era adequado para a realização de fotografias } \\
\text { panorâmicas? Explique? }\end{array}$} \\
\hline & Adequado $=3$ & $\begin{array}{l}\text { Sim para este tipo de fotografia em que o foco, na maioria dos } \\
\text { casos, é o infinito. }\end{array}$ \\
\hline \multirow[b]{2}{*}{6} & \multicolumn{2}{|c|}{$\begin{array}{l}\text { O uso da câmera do dispositivo era adequado para a realização de fotografias de } \\
\text { média distância? Explique? }\end{array}$} \\
\hline & $\begin{array}{l}\text { Adequado com } \\
\text { ressalvas }=2\end{array}$ & $\begin{array}{l}\text { A câmera interna pode ser utilizada, porém, em alguns casos } \\
\text { será necessário utilizar a câmera externa divido a necessidade } \\
\text { de ajustar o foco }\end{array}$ \\
\hline
\end{tabular}




\begin{tabular}{|c|c|c|}
\hline \multirow[b]{2}{*}{7} & \multicolumn{2}{|c|}{$\begin{array}{l}\text { O uso da câmera externa acoplada ao dispositivo era adequado para a realização } \\
\text { de fotografias de detalhes? Explique? }\end{array}$} \\
\hline & Adequado = 3 & $\begin{array}{l}\text { Muito bom. A capacidade de se ajustar a câmera (foco, } \\
\text { iluminação, profundidade de campo) durante os exames facilita } \\
\text { em muito a visualização e percepção dos detalhes }\end{array}$ \\
\hline \multirow{2}{*}{8} & \multicolumn{2}{|c|}{$\begin{array}{l}\text { O programa (adquirido) de medição de grandezas físicas era adequado? } \\
\text { Explique? }\end{array}$} \\
\hline & Adequado $=3$ & $\begin{array}{l}\text { Bom, pois para medir a ferramenta coletada foi muito fácil e } \\
\text { rápido. }\end{array}$ \\
\hline \multirow[b]{2}{*}{9} & \multicolumn{2}{|c|}{$\begin{array}{l}\text { O programa (adquirido) de elaboração de croquis de feições dos suspeitos era } \\
\text { adequado? Explique? }\end{array}$} \\
\hline & $\begin{array}{l}\text { Adequado com } \\
\text { ressalvas }=2\end{array}$ & $\begin{array}{l}\text { O programa utilizado deveria ser melhorado com a adição de } \\
\text { mais biótipos (para os padrões brasileiros) e de cores da pele, } \\
\text { cabelo e olhos }\end{array}$ \\
\hline \multirow[b]{2}{*}{10} & \multicolumn{2}{|c|}{ O programa (adquirido) de leitura de código de barras era adequado? Explique? } \\
\hline & $\begin{array}{l}\text { Adequado com } \\
\text { ressalvas }=2\end{array}$ & $\begin{array}{l}\text { Deveria haver uma planilha já no próprio sistema que } \\
\text { recebesse diretamente o número do código de barras }\end{array}$ \\
\hline \multirow{2}{*}{11} & \multicolumn{2}{|c|}{$\begin{array}{l}\text { A função macro do editor de texto utilizada na elaboração dos laudos era } \\
\text { adequada? Explique? }\end{array}$} \\
\hline & Adequado = 3 & $\begin{array}{l}\text { Muito boa e rápida, apesar de trazer mais informações que os } \\
\text { laudos atualmente elaborados. }\end{array}$ \\
\hline \multirow{2}{*}{12} & \multicolumn{2}{|c|}{ O treinamento efetuado foi adequado? Explique? } \\
\hline & Adequado $=3$ & Sim, o uso do programa é quase intuitivo. \\
\hline \multirow[b]{2}{*}{13} & \multicolumn{2}{|c|}{ Efetue sugestões para a melhora do sistema. } \\
\hline & $\begin{array}{l}\text { Adequado com } \\
\text { ressalvas }=2\end{array}$ & $\begin{array}{l}\text { Deveria haver mais módulos para outros tipos de crimes e } \\
\text { situações, tais como para coleta de projetis e pneumáticos. }\end{array}$ \\
\hline
\end{tabular}


Para este entrevistado o sistema recebeu trinta e três (33) pontos com o uso de todos os recursos. Sua média foi de dois pontos e cinquenta e três décimos $(2,53)$, ou seja, próximo ao máximo, indicando assim que o sistema é adequado para o uso devendo ser efetuados estudos para a melhoria dos tópicos com pontuação mais baixa.

4) $O$ quarto perito, utilizando um texto baseado no laudo com lacunas a preencher realizou três (exames) e teve o tempo médio de vinte e três (23) minutos. Não foram colhidos vestígios materiais.

\begin{tabular}{|c|c|c|c|}
\hline № & $\begin{array}{l}\text { Tipo do } \\
\text { Local }\end{array}$ & Evidências coletadas & $\begin{array}{l}\text { Tempo } \\
(\mathrm{min})\end{array}$ \\
\hline 1 & Residência & Uma (1) impressão de pneumático & 25,75 \\
\hline 2 & Residência & Uma (1) fotografia de impressão digital & 20 \\
\hline 3 & Escritório & Uma (1) fotografia palmar & 16,25 \\
\hline 4 & Escola Pública & $\begin{array}{c}\text { Uma (01) fotografia de impressão } \\
\text { palmar }\end{array}$ & 17,25 \\
\hline 5 & Residência & 0 & 12,25 \\
\hline 6 & Residência & $\begin{array}{l}\text { Uma marca de arrombamento e uma } \\
\text { ferramenta (barra de ferro) }\end{array}$ & 29 \\
\hline 7 & Oficina mecânica & $\begin{array}{l}\text { Duas (2) impressões digitais e uma (1) } \\
\text { impressão de pneumático }\end{array}$ & 26,25 \\
\hline 8 & $\begin{array}{l}\text { Poste elétrico } \\
\text { (furto de fios de } \\
\text { cobre) }\end{array}$ & 0 & 11 \\
\hline 9 & Residência & $\begin{array}{l}\text { Uma (1) fotografia de pegada e uma } \\
\text { (1) fotografia de marca de pneumático }\end{array}$ & 24,25 \\
\hline 10 & Residência & Um (1) esboço de feição de suspeito & 18,25 \\
\hline 11 & Escritório & 0 & 11 \\
\hline 12 & Residência & Um (1) esboço de feição de suspeito & 20,75 \\
\hline 13 & Residência & 0 & 14 \\
\hline 14 & Escritório & 0 & 12,25 \\
\hline
\end{tabular}




\begin{tabular}{|c|c|c|c|}
\hline 15 & Residência & Um (1) esboço de feição de suspeito & 22 \\
\hline 16 & Escola Pública & 0 & 13,75 \\
\hline \multicolumn{2}{|r|}{} & Média & $\mathbf{1 8 , 3 7 5}$ \\
\hline
\end{tabular}

Tabela 11 - Anotação da coleta de evidências nos locais versus tempo necessário (Perito (4))

O tempo médio foi de dezoito minutos e trezentos e setenta e cinco milésimos (18,375 minutos).

\section{Questionário:}

\begin{tabular}{|c|c|c|}
\hline № & & DESCRITIVO \\
\hline \multirow[b]{2}{*}{1} & \multicolumn{2}{|c|}{ A ergometria do dispositivo era adequada para o uso em campo? Explique? } \\
\hline & Adequado = 3; & $\begin{array}{l}\text { Usar o tablet é mais prático que o uso de pranchetas com } \\
\text { folhas avulsas }\end{array}$ \\
\hline \multirow[b]{2}{*}{2} & \multicolumn{2}{|c|}{ A sequência das telas era adequada para a realização dos exames? Explique? } \\
\hline & $\begin{array}{l}\text { Adequado com } \\
\text { ressalvas }=2\end{array}$ & $\begin{array}{l}\text { Como os questionários colhem muitas informações e medidas } \\
\text { deveria haver telas focadas somente na coleta de informações } \\
\text { e outras na realização de medidas }\end{array}$ \\
\hline \multirow{2}{*}{3} & \multicolumn{2}{|c|}{$\begin{array}{l}\text { Nos questionários apresentados o tamanho das letras era satisfatório para a } \\
\text { realização da leitura rápida? Explique? }\end{array}$} \\
\hline & $\begin{array}{l}\text { Adequado } \text { com } \\
\text { ressalvas }=2\end{array}$ & Deveriam ser maiores \\
\hline \multirow{2}{*}{4} & \multicolumn{2}{|c|}{$\begin{array}{l}\text { O uso do teclado virtual (tela sensível) era adequado para o preenchimento dos } \\
\text { formulários? Explique? }\end{array}$} \\
\hline & $\begin{array}{l}\text { Adequado } \text { com } \\
\text { ressalvas }=2\end{array}$ & $\begin{array}{l}\text { É bom, mas deveria haver um teclado físico como reserva para } \\
\text { ser usado quando se tiver que coletar muitas informações }\end{array}$ \\
\hline
\end{tabular}




\begin{tabular}{|c|c|c|}
\hline \multirow[t]{2}{*}{5} & \multicolumn{2}{|c|}{$\begin{array}{l}\text { O uso da câmera do dispositivo era adequado para a realização de fotografias } \\
\text { panorâmicas? Explique? }\end{array}$} \\
\hline & Adequado $=3$ & Para fotos panorâmicas é bom \\
\hline \multirow{2}{*}{6} & \multicolumn{2}{|c|}{$\begin{array}{l}\text { O uso da câmera do dispositivo era adequado para a realização de fotografias de } \\
\text { média distância? Explique? }\end{array}$} \\
\hline & $\begin{array}{l}\text { Adequado } \mathrm{com} \\
\text { ressalvas }=2\end{array}$ & $\begin{array}{l}\text { Como não tem zoom foi necessário caminhar para procurar um } \\
\text { enquadramento da cena para se fotografar }\end{array}$ \\
\hline \multirow{2}{*}{7} & \multicolumn{2}{|c|}{$\begin{array}{l}\text { O uso da câmera externa acoplada ao dispositivo era adequado para a realização } \\
\text { de fotografias de detalhes? Explique? }\end{array}$} \\
\hline & Adequado $=3$ & $\begin{array}{l}\text { O uso do tablet permite ver a qualidade da foto e, isso, ajuda } \\
\text { muito }\end{array}$ \\
\hline \multirow{2}{*}{8} & \multicolumn{2}{|c|}{$\begin{array}{l}\text { O programa (adquirido) de medição de grandezas físicas era adequado? } \\
\text { Explique? }\end{array}$} \\
\hline & $\begin{array}{l}\text { Adequado com } \\
\text { ressalvas }=2\end{array}$ & $\begin{array}{l}\text { É boa para objetos pequenos que podem ser levados próximos } \\
\text { a tela, mas, para objetos grandes a precisão não é boa }\end{array}$ \\
\hline \multirow{2}{*}{9} & \multicolumn{2}{|c|}{$\begin{array}{l}\text { O programa (adquirido) de elaboração de croquis de feições dos suspeitos era } \\
\text { adequado? Explique? }\end{array}$} \\
\hline & $\begin{array}{l}\text { Adequado com } \\
\text { ressalvas }=2\end{array}$ & Deveria poder alterar a cor da pele, olhos e cabelo \\
\hline \multirow[b]{2}{*}{10} & \multicolumn{2}{|c|}{ O programa (adquirido) de leitura de código de barras era adequado? Explique? } \\
\hline & $\begin{array}{l}\text { Adequado com } \\
\text { ressalvas }=2\end{array}$ & $\begin{array}{l}\text { Deveria haver uma planilha no tablet para ler diretamente o } \\
\text { código de barras }\end{array}$ \\
\hline \multirow{2}{*}{11} & \multicolumn{2}{|c|}{ O macro utilizado na elaboração dos laudos era adequado? Explique? } \\
\hline & Adequada $=3$ & É boa \\
\hline \multirow[b]{2}{*}{12} & \multicolumn{2}{|c|}{ O treinamento efetuado foi adequado? Explique? } \\
\hline & $\begin{array}{l}\text { Adequado com } \\
\text { ressalvas }=2\end{array}$ & Deveria ser mais detalhado \\
\hline
\end{tabular}




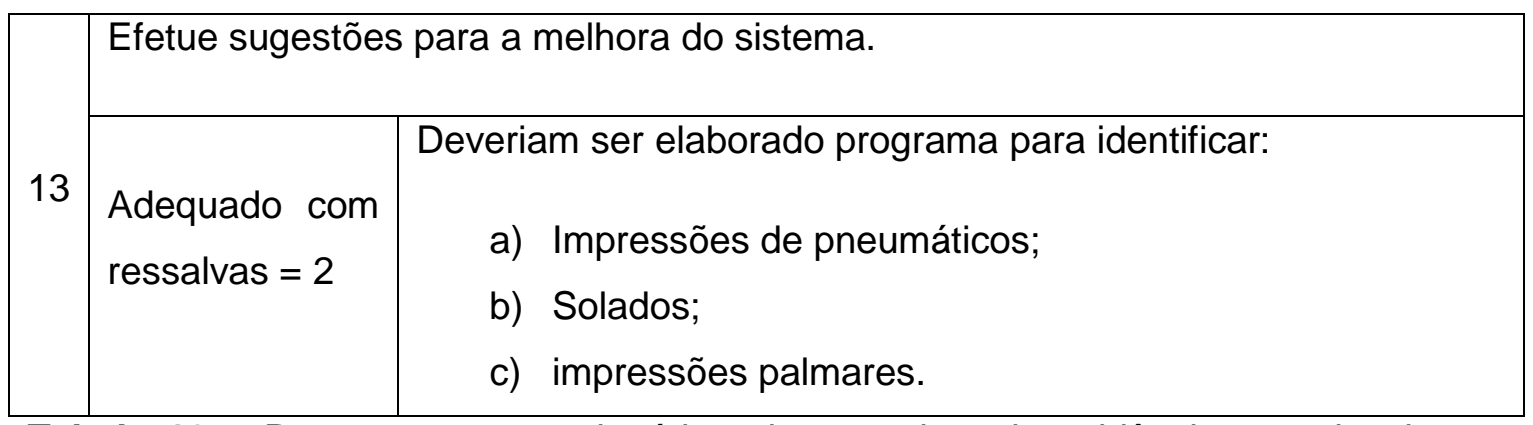

Tabela 12 - Repostas ao questionário sobre a coleta de evidências nos locais de exame (Perito (4))

Com pontuação de trinta e um (31) pontos utilizando todos os recursos e, média de dois pontos e trinta e oito décimos, ou seja, próximo à média de "adequado com ressalvas", a enquete aponta para a necessidade da realização de estudos para os itens com baixa pontuação.

\subsection{Análise dos Resultados}

\subsubsection{Tempo gasto nos exames}

Considerando-se que:

1) Os locais e situações examinados apresentam características diversas entre si, o que dificulta uma comparação efetiva entre exames;

2) Cada perito realizou na verdade duas tarefas simultaneamente (realização dos exames usando o tablet e instrução do Fotógrafo Técnico-pericial para o preenchimento de seu método de exame); 
3) O volume de informações e dados no sistema proposto é muito maior que o volume de informações coletadas pelos peritos nos seus métodos individuais;

O tempo gasto médio foi de dezesseis minutos e setenta centésimos $(16,70)$, ou seja, inferior ao tempo gasto nos métodos individuais.

\subsubsection{Tópicos do questionário}

Para a avaliação da adequação do sistema foram considerados os tópicos do questionário apresentado aos Peritos Criminais que efetuaram os exames.

\section{1) Ergometria:}

O item recebeu a pontuação média de três (3) pontos, ou seja, foi considerado adequado e os entrevistados em seus comentários informam que o manuseio do tablet é mais prático que o uso de pranchetas e formulários de papel.

\section{2) Sequência das telas:}

Com média de dois pontos e trinta e três décimos $(2,33)$ a análise indica que as telas poderiam ser usadas, porém, uma nova solução deveria ser estudada. Os comentários indicam que $\mathrm{o}$ procedimento deveria ser dividido em mais telas para que os peritos "se conscientizassem" melhor da operação que estão realizando.

3) Tamanho das letras nas telas:

Com média de um ponto e sessenta e seis $(1,66)$, a analise indica que $o$ item deve ser alterado e, seguindo os 
comentários, aumentando o tamanho das letras, ou seja, a visibilidade do texto para facilitar a leitura.

\section{4) Teclado virtual:}

A média de dois pontos e trinta e três décimos $(2,33)$ a enquete aponta para a necessidade da realização de um estudo sobre o problema. Os comentários indicam que os entrevistados tiveram um problema de adaptação ao equipamento e, que em certos momentos, quando a informação é volumosa o uso de um teclado físico é passível de emprego.

5) Câmera interna para fotos panorâmicas:

Com média de dois e sessenta seis $(2,66)$, ou seja, próximo à pontuação máxima a enquete aponta que o uso da câmera interna para a realização de fotos panorâmicas seria adequada para o uso corriqueiro.

6) Câmera interna para fotos de média distância:

A média de dois pontos (2) indica claramente que 0 recurso poderia ser utilizado, porém, não é o ideal e, a necessidade da alteração da distância focal foi citada por todos os peritos.

7) Câmera externa para fotos de detalhes:

Por outro lado, com média de três (3) pontos o recurso foi considerado um avanço por possibilitar produzir um bom ajuste da câmera externa para cada foto de detalhe e observar o resultado simultaneamente.

\section{8) Programa de medição de grandezas fixas:}

Considerando que somente dois dos peritos utilizaram o recurso sua média relativa foi de dois e meio $(2,50)$ pontos o recurso indica que é adequado para a 
leitura de pequenas dimensões. Mas, salientamos que 0 modulo para a leitura de dimensões maiores a baixa precisão é um fator que deve ser levado em conta para a realização de medidas.

\section{9) Programa para a elaboração de feições:}

Idêntico ao item (6.), com média de dois (2) pontos, o recurso poderia ser utilizado, mas os comentários dos entrevistados indicam que deveriam ser adicionados os biótipos mais comuns ao país e cores para a pele, cor dos olhos e cabelos.

10) Programa para leitura de código de barras:

Com média de dois (2) pontos o recurso encaixa na faixa dos recursos que poderiam ser utilizados, porém, deveriam receber uma complementação que no caso seria a existência de uma planilha de controle da cadeia de custódia que recebesse diretamente os códigos de barra das etiquetas dos envelopes dos vestígios coletados.

11) Função Macro do editor de texto para a elaboração de Laudos:

Com média de dois pontos e sessenta seis décimos $(2,66)$ o recurso, em um primeiro momento, foi considerado adequado para o uso.

12) Treinamento:

Com média de dois pontos e trinta e três décimos (2.33) a realização do treinamento mostrou-se parcialmente 
adequada. Os comentários indicam que um treinamento mais detalhado (e extenso) deveria ser realizado.

13) Melhora do Sistema:

A pontuação média de dois pontos indica que o sistema poderia ser utilizado, porém, com modificações e aperfeiçoamentos. Os comentários sugerem a adição de recursos de emprego no dia a dia dos peritos, tais como:

- A fotografia e analise de solados;

- A fotografia e analise de impressão de pneumáticos;

- A fotografia e analise de impressões palmares;

- Etc.

\subsection{Conclusões}

Em face dos resultados obtidos, conclui-se que o dispositivo de coleta de dados para o sistema:

1) É de fácil manuseio em campo (ergonomia) e, principalmente, não exige longos treinamentos;

2) Permite a coleta de mais informações e dados com um menor gasto de tempo;

3) Permite a realização de análises iniciais que podem auxiliar os peritos a definir a complementação de seus procedimentos;

4) Propicia a formação, em tempo real, de um banco de dados interativo e, por via de consequência, de uma expertise, num modelo inédito, onde é previsto um retorno dos dados enviados já interpretados e com especificações técnicas acerca do assunto sob exame. 


\section{0 - DISCUSSÃO SOBRE O PROSSEGUIMENTO DOS ESTUDOS}

\section{1 - Identificação das necessidades futuras}

A análise dos questionários apresentados no capítulo quatro mostraram claramente que para a implementação pratica do sistema proposto esta pesquisa deve continuar com o desenvolvimento de metodologias de coleta (produção) de imagens, analise e arquivamento para os vestígios:
a) Impressões de digitais;
b) Perfis de projeteis e culotes de cartuchos.
c) Impressões de pneumáticos;
d) Impressões de solados;
e) Impressões de pegadas;
f) Impressões palmares, e;
g) Marcas de ferramentas
h) Croquis de locais, e;
i) Feições de suspeitos.

Um estudo inicial na literatura especializada mostrou que para os itens " $\boldsymbol{a}$ " e " $\boldsymbol{b}$ " já existem técnicas consolidadas internacionalmente para a coleta (produção) de imagens, analise e a comparação para a identificação de suspeitos e, que estas técnicas podem ser facilmente implementadas ao sistema.

Uma análise simplificada mostrou que a mesma metodologia, com ligeiras alterações, poderia ser empregada para os itens "c", "d", "e", "f", e "g", no entanto, como é patente que no Brasil não existem bancos de dados para a realização de comparação e identificação seu uso fica fortemente condicionado a "alimentação" e "consolidação".

No caso dos itens "h" e, "i" em que as informações (e dados) são geradas por computação gráfica, além do desenvolvimento de rotinas gráficas, 
será necessário à realização de estudos adicionais para a obtenção de tipos (perfis de móveis, ruas, etc. e biótipos) condizentes com a nossa realidade.

\section{2 - Metodologias necessárias}

No entanto, complementarmente, em face da já citada ausência de normatizações para o assunto no Brasil, para cada vestígio citado acima será necessário à criação e padronização de:

1. Metodologia especifica de produção de imagens;

2. Método de conversão das imagens em arquivos compatíveis com os padrões internacionais;

3. Método para a análise e comparação dos arquivos;

4. Procedimento de alimentação do banco de dados.

Que serão delineadas a seguir.

\subsection{1 - Metodologia especifica de produção de imagens}

Diferentemente do método de produção de imagens panorâmicas e de média distância em que é utilizada iluminação direta (a) com uma fonte pontual e em ângulo normal com o plano de fundo em que se encontra o que se quer mostrar, a fotografia de vestígios e de detalhes, para a obtenção do contraste necessário a sua correta individualização, deve empregar fontes de luz difusa $(\boldsymbol{b})$ ou iluminação rasante $(\boldsymbol{c})$. 


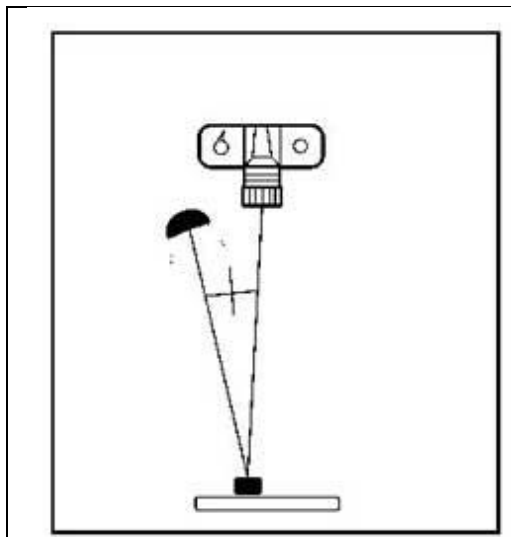

a) Iluminação direta

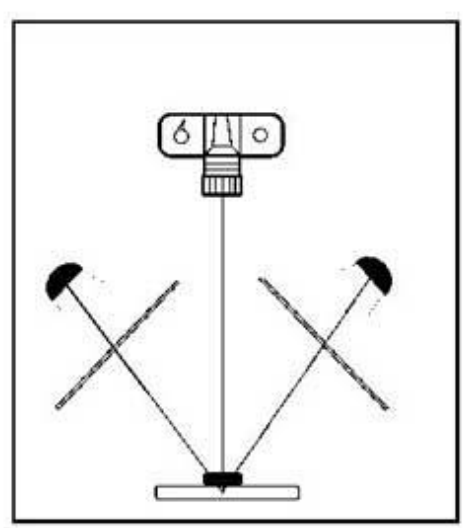

b) Iluminação difusa

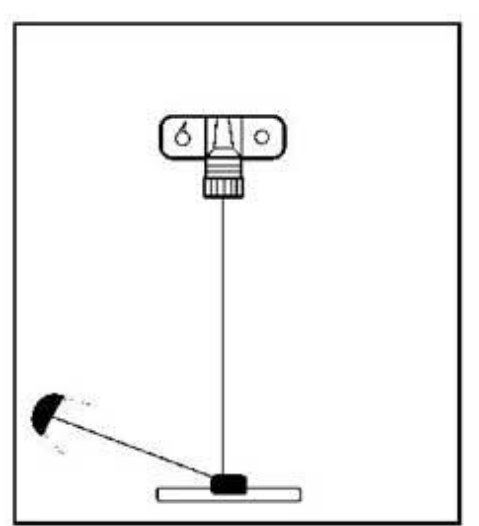

c) Iluminação rasante

\section{Figura 12 - Modos de lluminação}

Extraído de "Crime Scene and Evidence Photographer's Guide Second Edition" (Staggs 2005)

Por exemplo, abaixo à esquerda encontra-se uma imagem de marca de solado na qual foi empregada apenas à iluminação com ângulo próximo a noventa graus de incidência - "iluminação direta" (foto 5) e, à direita encontrase a imagem obtida com o emprego de iluminação com ângulo oblíquo ao cenário "ângulo rasante" (foto 6 ).

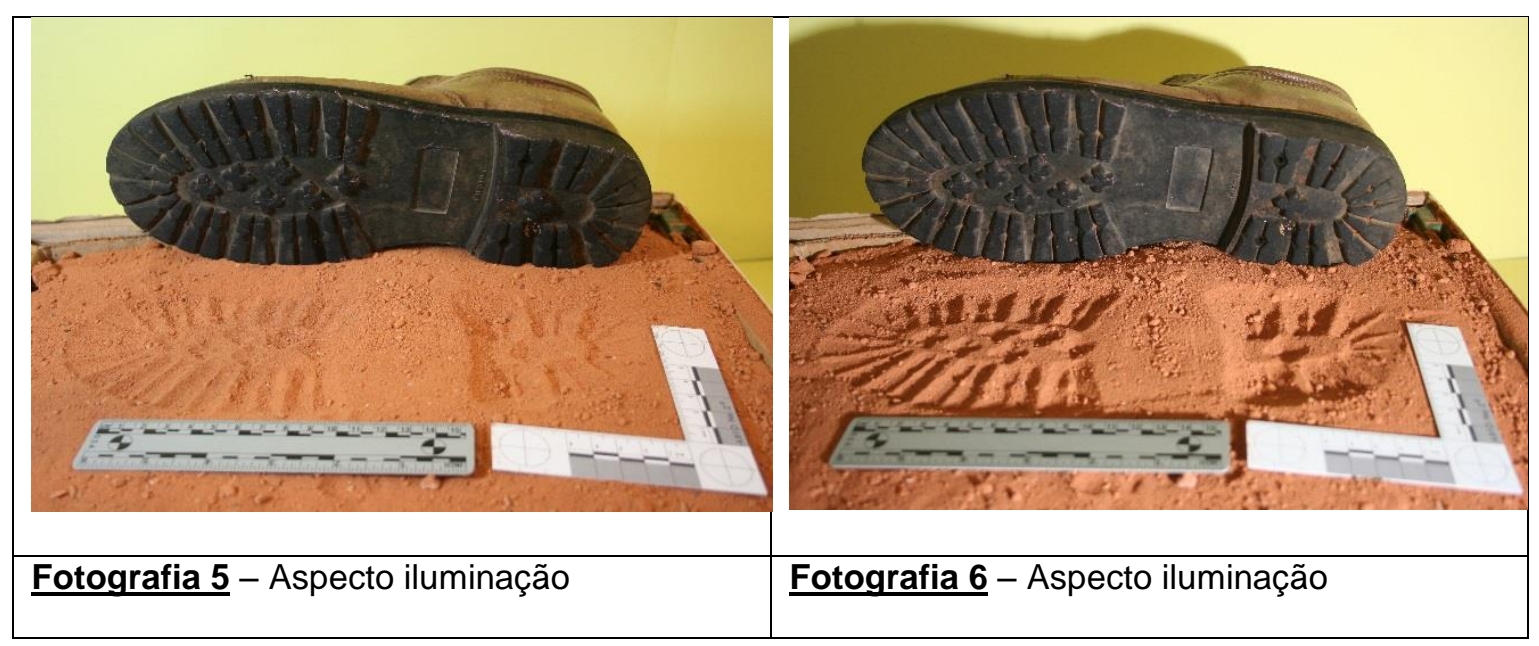


Observa-se que com a iluminação direta os contornos das depressões são difíceis de serem distinguidos, enquanto que, com a iluminação rasante são mais facilmente percebidos e medidos.

Porém, no Brasil, devido à falta dos acessórios necessários (tripé com inversão de cabeçote, cabos de extensão de flash, lanternas de luz polarizada, etc.), apenas o método a) é empregado e, como consequência, a grande maioria das imagens produzidas não permitem uma comparação efetiva.

No entanto, nos testes de campo realizados para os procedimentos de produção de imagens utilizando o dispositivo de coleta (tablet) integrado a câmera externa os equipamentos auxiliares para a iluminação rasante foram empregados e, os questionários mostraram que seu uso implicitamente foi considerado "muito fácil" e "ergonômico".

\subsection{2 - Método de conversão das imagens em arquivos}

Pierce (2009) citou que para a análise das imagens de vestígios e detalhes na produção deveriam ser empregados, além da maior resolução possível, marcadores dimensionais (réguas $\mathrm{ABO}$ ) para obtenção de dimensões de referência. Utilizando programas de computação gráfica, no caso "Adobe Photoshop", converter as imagens brutas (RAW) para a dimensão 1:1.

Costa (2001), estudando a implementação de um sistema de análise de impressões digitais, salienta que as imagens produzidas devem ser tratadas na sequencia abaixo:

> Inicialmente convertidas para $500 \mathrm{dpi}^{27}$;

$>$ Convertidas de imagens a cores para tons de cinza;

> Convertidas de tons de cinza para "preto e branco";

> Filtradas para a eliminação de borrões (suavização);

${ }^{27}$ Dpi: pontos por polegada 
Filtrada para o adensamento das minucias, e;

Conversão das minucias em linhas e pontos (afinamento).

\subsection{3 - Métodos para a análise e comparação dos arquivos}

Há muitos métodos de análise e comparação das imagens digitais com vestígios encontrados em local de crime, porém, quando ocorre a individualização de um suspeito, como, por exemplo, o encontro de uma impressão digital (unicidade), para a aceitação nas cortes de Justiça (Saks e Koehler 2008) cita a obrigatoriedade da possibilidade da realização de comparação convencional:

> Comparação convencional;

> Comparação entre a imagem digital e o objeto em que a imagem encontra-se na escala de 1:1 e, é possível identificar a quantidade mínima de pontos correspondentes que garantem a individualização do acusado;

Comparação com ampliação;

Quando as dimensões do objeto a ser compactado são pequenas, para a apresentação na corte, pode efetuar a ampliação; mantendo-se a mesma escala, da imagem coleta no local e da imagem do detalhe em questão;

> Comparação usando um ponto de referência;

> O método mais comum empregado para a análise de diversos tipos de vestígios deriva do método empregado por Henry e Galton, no qual se estabelece um ponto central e se efetua uma análise polar na procura de pontos singulares idênticos das imagens em estudo.

Analise de Fourier;

Park e Park (2005) mostraram que com a utilização da transformada de Fourier é possível se efetuar a 
análise de detalhes (minucias) que se encontra em ângulos diferentes;

\subsection{4 - Procedimento de alimentação do banco de dados}

Nas investigações criminais a identificação de caminho da investigação a seguir é denominada determinação das pistas. A determinação das pistas, se realizada de modo científico, se constitui na pesquisa para relacionar vestígios encontrados em locais de crime com evidências físicas encontradas no universo de estudo.

Por exemplo, Geradts e Keijzer (1996) mostraram que a criação de um banco de dados de solados de sapatos comprados em lojas proporcionou um acréscimo substancial na identificação de suspeitos que cometem os crimes de forma serial.

Em outro exemplo, MacDonald (1993) mostrou que uma marca de pneumático encontrada nas proximidades de um crime pode, através de pesquisa em bancos de dados, indicar a marca do veículo do suspeito, no entanto, atualmente no país é a tarefa que menos produz resultados devido ao fato que muitas vezes não há arquivos sobre o vestígio, ou os arquivos são incompletos ou desatualizados.

Paralelamente a determinação das "pistas", o relacionamento (identificação) de suspeito com o crime que é uma tarefa mais complexa, pois, implica na identificação de uma característica única (unicidade) que individualiza determinada pessoa do universo de pesquisa.

Por exemplo, um pneumático de um determinado tipo e marca que tenha um corte específico em sua banda de rodagem produz uma impressão única e, já havendo um veículo suspeito, este poderá ser relacionado (identificado) com o ato criminoso.

O sistema proposto foi desenvolvido com a ideia de que todos os vestígios coletados em campo, além de servirem como elementos de relacionamento (identificação) de suspeitos, possam ser usados para a 
determinação das pistas, pois, alimentam um conjunto de bancos de dados com o "traço" ou "impressão" encontrada e, quando possível com suas as características, tais como fabricante, modelo, veículo em que é aplicado, etc.

Desse modo, mesmo que a análise da ocorrência criminal em estudo não obtenha resultados conclusivos na identificação do agente delituoso, os dados coletados em pericias anteriores de mesmo fulcro podem ser cruzados e, por via de consequência, possibilitar aos investigadores uma identificação positiva do suspeito.

A esta característica do sistema denominamos "Formação de Expertise", que na verdade é uma maneira rápida e barata para criar e alimentar os bancos de dados necessários.

\section{3 - Pesquisas em desenvolvimento}

\subsubsection{Impressões de Pneumáticos}

Utilizando a técnica pela "National
Forensic Science Technology
Center (NFSTC)" em cooperação
com o "Bureau of Justice Assistance
(BJA)", órgão do Departamento de
Justiça dos Estados Unidos
iniciamos a coleta de impressões de
pneumáticos de veículos vistoriados
pelos peritos criminais.




Utilizando o sistema de coleta de
dados acoplado à câmera de alta
resolução as impressões foram
fotografadas em modo "RAW" para
uma melhor caracterização de suas
minucias.
$\begin{aligned} & \text { banco de dados } 28 \text { criado } \\ & \text { provisoriamente foi alimentado com } \\ & \text { quarenta e oito (48) impressões e } \\ & \text { com suas marcas, modelos e } \\ & \text { veículos na qual são encontrados. }\end{aligned}$

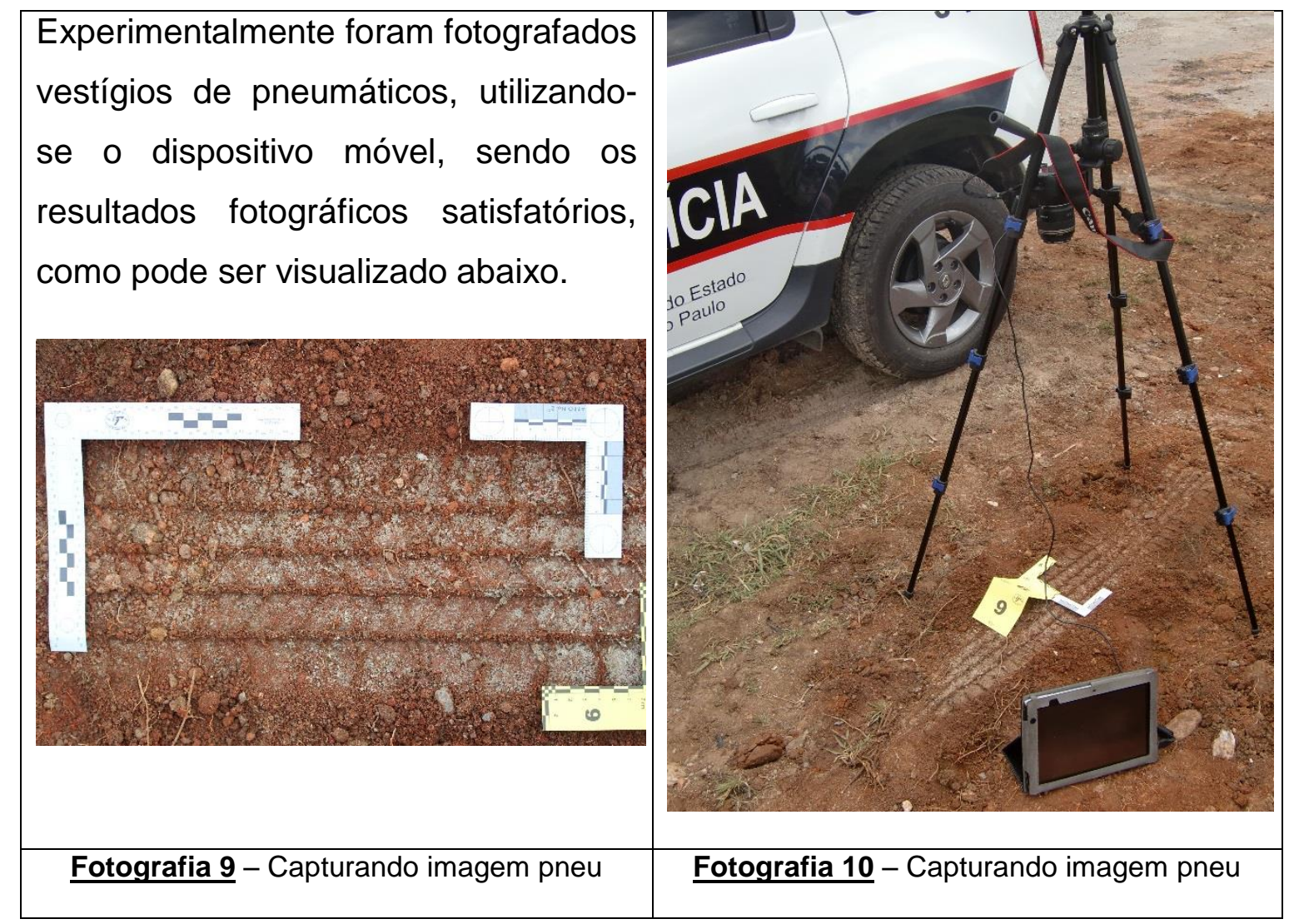

\footnotetext{
${ }^{28} \mathrm{O}$ banco de dados foi inicialmente (e provisoriamente) criado utilizando o programa Excel do Windows.
} 
No presente momento, um programa de análise de impressões de pneumáticos está sendo escrito na linguagem MATLAB que rodará inicialmente no computador central e, no futuro, após comprovação pratica de funcionalidade, será convertido para uso em dispositivos com a plataforma ANDROID, possibilitando assim que sejam empregados diretamente no dispositivo móvel de coleta (tablet).

\subsubsection{Desenho de faces (rosto) e croquis}

Também, no presente momento, encontra-se em estudo inicial o desenvolvimento de rotinas para a produção de desenho de faces e croquis de locais de crime.

Infelizmente, o desenvolvimento desta rotina que, obrigatoriamente trabalhará em modo gráfico, tem apresentado sérias dificuldades na sua elaboração em linguagem $A N D R O I D$, especialmente agravadas pelo fato de a população brasileira ser oriunda de etnia multirracial, impondo assim que a biblioteca do sistema necessariamente venha a possuir os biotipos de muitas raças. 


\subsection{REFERÊNCIAS}

ALMEIDA, P. H. B., AZEVEDO R.. Modelos mentais: um estudo de caso referente à introdução de computadores no ensino, Universidade Estadual de Campinas. Disponível: <http://www.lbd.dcc.ufmg.br/colecoes/wie/2009/005.pdf >.

ALVES, F. F.. Desenvolvimento de aplicação Biométrica para reconhecimento de impressão digital através de um dispositivo móvel. Monografia apresentada ao Departamento de Ciência da Computação da Universidade Federal da Bahia. Bahia, 2007.

BEATO F, CLAUDIO C.. Determinantes da criminalidade em Minas Gerais. Revista Brasileira de Ciências Sociais. Print version ISSN 0102-6909. Rev. bras. Ci. Soc. vol. 13 n. 37 São Paulo June 1998.

BENNETT D.. The Challenges Facing Computer Forensics Investigators in Obtaining Information from Mobile Devices for Use in Criminal Investigations. Information Security Journal: A Global Perspective, 2012. 21:3, p159-168.

BULKA T., AGARWAL C. AND POZDNYAKOV P. Secure Mobile Fingerprint Identification System, Submitted in School of Engineering. Santa Clara University, 2005.

BURROWS J. et all. Forensic Science Pathfinder project: evaluating increased forensic activity in two English police forces. Home Office online Report 46/05, ISBN 1-84473-763-2, @ Crow copyright, 2005, 
CHEONG HEE PARK AND HAESUN PARK. Fingerprint Classification using Fast Fourier Transform and Nonlinear Discriminant Analysis. Dept. of Computer Science and Engineering. University of Minnesota Minneapolis. 2005 Elsevier.

COOPER C. Eyewitness Forensic Science. ISBN 978-0-7566-3383-7, New York, Dorling Kindersley Limited, 2008.

DALE W. M. and BECKER W. S. The Crime Scene: How Forensic Science Works. ISBN-13: 978-1-4277-9632-5, Northeast Regional Forensic Institute, Kaplan Publishing, New York, 2007.

DINIZ, MILENA ESTANISLAU e MARCOS PEREIRA ESTELLITA LINSB. PERCEPÇÃO E ESTRUTURAÇÃO DE PROBLEMAS SOCIAIS UTILIZANDO MAPAS COGNITIVOS. Brasil, UFRJ, Rio de Janeiro; Produção, v. 22, n. 1, p. 142154, jan./fev. 2012.

DUGLOSZ et al., Uso do levantamento aéreo expedito convencional e digital para o monitoramento da cobertura florestal no Paraná: estado da arte e potencialidades, Pesquisa florestal Brasileira. Colombo, v. 30, n. 63, p245 262, ago/out. 2010.

FBI ACADEMY. Crime Scene Photography Requirements of Criminal Investigative Analysis, Behavioral Science Investigative Support Unit. FBI Academy, Quantico, Virginia 22135.

FRIED R. B. DIGITAL PHOTOGRAPHY: An In Depth Analysis of an Emerging Tread within the Computer Age. 
GARRIDO, ADRIANA CRISTINA OLIVER, et al. Fatores sociais de criminalidade.

Disponível:www.atenas.edu.br/faculdade/arquivos/NucleolniciacaoCiencia/.../5.pdf. Minas Gerais. 2008.

GAZETA

DO

POVO.

Disponível:

<http://www.gazetadopovo.com.br/vidaecidadania/conteudo. phtml?id=788728>

GELLERSEN H., SCHMIDT A., BEIGL M. Multi-Sensor Context-Awareness in Mobile Devices and Smart Artifacts, Mobile Network and Applications. Springer 2002.

GIOVANELLI, ALEXANDRE e GARRIDO, RODRIGO GRAZINOLI. A perícia criminal no Brasil como instância legitimadora de práticas policiais inquisitoriais. Revista do Laboratório de Estudos da Violência da UNESP/Marília. 2011 - ISSN 1983-2192.

GIACALONE J. L. The Criminal Investigative Function - A guide for new Investigators. ISBN 978-1-60885-023-5, Loose leaf Law Publications, New York, 2011.

GLOBO, O. Disponível em: http://oglobo.globo.com/pais/mat/2011/09/04/faltade-investigacao-de-homicidios-resulta-em-fracasso-institucional-alertamentidades-925285157.asp\#ixzz1X4dVsSjQ

GLOE T. et all. Can we Trust Digital Image Forensics?. MM'07, September 2328, 2007. 
GUADAGNO L. et all. Using PDAs for Data Collection, Applied Nursing Research. v. 17, n. 4 (November), p. 283-291, 2004.

HINCLEY K., et al, Sensing Techniques for Mobile Interaction, Communications of 13 the annual ACM Congress. 2000.

HINCLEY K. et al. Foreground and Background Interaction with SensorEnhanced Mobile Devices, ACM Transactions on Computer-Human Interactions. Vol. 12, No. 1, March 2005, p. 1-22.

IPEA. Segurança Publica. Disponível: http://agencia.ipea.gov.br/images/stories/PDFs/SIPS/110330. Publicado em 30 de março de 2011

JORNAL FOLHA DE SÃO PAULO. Versão on line de 16 de Julho de 2011; Disponível em < folha.com.br >. Acesso em: 04 de Setembro de 2011.

LEE H. C., PALMBACH T., MILLER M. T.. Henry Lee's Crime Scene Handbook. ISBN: 978-0-12-440830-2, China, 2011, 1르 ed.

LOPES, JOSÉ REINALDO DE LIMA. DIREITOS HUMANOS E TRATAMENTO IGUALITÁRIO: QUESTÕES DE IMPUNIDADE, DIGNIDADE E LIBERDADE. REVISTA BRASILEIRA DE CIÊNCIAS SOCIAIS - VOL. 15, p.42. 2000.

McDONALD P.. Tire Imprint Evidence; ISBN: 0-8493-9515-1; CRC Series in practical aspects of criminal and forensics investigations; CRC; 1993. 
MICHAEL J. SAKS* \& JONATHAN J. KOEHLER. The Individualization Fallacy in Forensic Science Evidence. 2008; VANDERBILT LAW REVIEW [Vol. 61:1: p.199 $-200]$

MISLAN R.P., CASEY E. and KESSLER G.C. The growing need for on-scene triage of mobile devices, Digital Investigations. v. 6, p. 112-124, 2010.

NATIONAL FORENSIC SCIENCE TECHNOLOGY CENTER. A Simplified Guide To Footwear \& Tire Track Examination; site: <http://www.crime-sceneinvestigator.net/ SimplifiedGuideFootwearTireTracks.pdf>

NAGOSKY D. P.. The Admissibility of Digital Photographs in Criminal Case. FBI Law Enforcement Bulletin. 2005.

NEWTON M.. The Encyclopedia of Crime Scene Investigator. ISBN-10: 0-81606815-1, New York, Checkmark Books, 2008, p. 65.

OGLE Jr. R. R.. Crime Scene Investigation \& Reconstruction - 2 ed. ISBN: 013-188607-X, Pearson Education Prentice Hall, New Jersey, 2007.

PATTEN B., SÁNCHEZ I. A. and TANGNEY B.. Designing collaborative, constructionist and contextual applications for handheld devices. Computer \& Education, p. 294-308, 2006.

PEIXOTO, B. T.; LIMA, R. S.; DURANTE, M. O.. Metodologias e Criminalidade Violenta no Brasil; São Paulo em Perspectiva, 18(1), 13 - 21, 2004; Disponível em < http://www.scielo.br/pdf/spp/v18n1/22222.pdf> . Acesso em: 04 set 2011. 
PIERCE, GUY. Resizing Digital Images to Actual Size (1:1) Using Adobe® Photoshop ${ }^{\circledR}$. 2008. Journal of the Association for Crime Scene Reconstruction, Volume 15, Spring 2009: p. 13-16.

RIGHI T. and CELANI, G.. Tecnologias de displays interativos no processo de projetos arquitetônicos. XIV CONVENCION CIENTIFICA DE INGENIERIA Y ARQUITETURA, Cuba, 2008.

RODRIGUES C. V., SILDA M. T. and TRUZZI O. M. S.. Perícia Criminal: uma abordagem de serviços; Gestão \& Produção. v. 17, n. 4, p. 843-857, São Carlos, 2010.

SAVELLI L.. Basic crime scene investigation. ISBN 1-889031-99-2, Loose leaf Law Publications, USA, 2004.

SAFERSTEIN R.. Criminalistics: An introduction to Forensic Science. 7th ed., ISBN 0-13-013827-4, Prentice Hall, New Jersey, 2001.

SECRETÁRIA NACIONAL DE SEGURANÇA PÚBLICA. Análise das Ocorrências Registradas pelas Polícias Civis (Janeiro de 2004 a Dezembro de 2005); Disponível em <http://portal.mj.gov>. Acesso em: 03 set 2011.

SENCAR H. T. and MEMON N.. Overview of State-of-the-Art in Digital Forensics, Algorithms, Architectures and Information System Security Statistical Science and Interdisciplinary Research. v. 3, World Scientific Publishing Co. Pte. Ltd., 2009. 
SOUZA, GELSON AMARO. Falso julgamento de mérito 20 de março de 2011. Disponível: $\quad$ <http://www.tex.pro.br/tex/listagem-de-artigos/318-artigos-mar2011/7857-falso-julgamento-de-merito> Acesso em: 22 de Março de 2011.

STEVEN STAGGS. Crime Scene and Evidence Photographer's Guide. 2 ed. ISBN 1-933373-01-6 Published 2005.

STRAWN C.. Expanding the Potential for GPS Evidence Acquisition, Small Scale. Digital Forensic Journal, V. 3, № 1, June 2009, ISSN\# 1941-6164.

WAISELFISZ; J. J.. Mapa da Violência dos Municípios Brasileiros 2008; Ministério da Justiça 2008; Disponível em <http://portal.mj.gov>>. Acesso em: 03 set 2011. 


\subsection{GLOSSÁRIO}

Android

Código QR

Corpo de delito

cSS3

Draggabilly
É um sistema operacional baseado no núcleo do Linux para dispositivos móveis.

Sigla para Quick Response. Código de barras bidimensional e escaneável, com possibilidade de uso pela maioria dos telefones celulares equipados com câmera.

O corpo de delito é, em essência, aquele objeto material em que recaiu o próprio fato criminal, sobre o qual é realizada a perícia criminal a fim de determinar fatores como autoria, temporalidade, extensão de danos, etc. Tal procedimento é denominado de exame de corpo de delito.

Sigla para Cascading Style Sheets. Linguagem de folhas onde se define estilos para páginas web com efeitos de transição, imagem, e outros. Sua principal função é abolir as imagens de plano de fundo, bordas arredondadas, com transições e efeitos para criar animações de vários tipos.

Trata-se de uma biblioteca JavaScript para fazer elementos arrastáveis. Encontra-se disponível em http://draggabilly.desandro.com. 
Expertise

Font Awesome (ícones vetorizados)

Gigabyte

\section{HTML5}

É uma palavra de origem francesa que significa experiência, especialização, perícia. Consiste no conjunto de habilidades e conhecimentos de uma pessoa, de um sistema ou tecnologia. No meio policial se usa também o termo "Tirocínio", para se expressar a mesma idéia quando em referência aos conhecimentos profissionais de um policial muito experiente.

Biblioteca utilizada para desenhar ícones como fontes no JSF (fontsawesome-http://fontawesome.io/icons).

Unidade de medida de informação, segundo o Sistema Internacional de Unidades - S.I., que equivale a um bilhão de bytes.

Abreviação para a expressão inglesa HyperText Markup Language 5, que significa = Linguagem de Marcação de Hipertexto; é a quinta versão desta linguagem e tem por serventia a estruturação e apresentação de conteúdo para a World Wide Web. É uma linguagem de marcação utilizada para produzir páginas na Web. Esta nova versão traz consigo mudanças através de novas funcionalidades como semântica e acessibilidade. 
Modus operandi

Indício

iOS

Java

JavaScript outra ou outras circunstâncias,
É uma linguagem

de

Expressão em latim que significa "modo de operação". Utilizada para designar uma maneira de agir, operar ou executar uma atividade seguindo sempre os mesmos procedimentos.

Circunstância conhecida e provada, que, tendo relação com o fato, autorize, por indução, concluir-se a existência de podendo estas serem materiais ou circunstanciais.

Sistema operacional móvel criado pela Apple Inc para emprego em seus equipamentos.

É uma linguagem de programação orientada a objeto. A linguagem Java é compilada para um bytecode que é executado por uma máquina virtual.

programação interpretada

Sigla para "Java Script Object Notation". Subconjunto da notação de objeto de JavaScript, utilizado para intercâmbio de dados computacionais. 
jQuery

É uma biblioteca JavaScript crossbrowser desenvolvida para simplificar os scripts que interagem com o HTML.

SGBD

Sigla em inglês para Gerenciamento de Banco de Dados. Conjunto de programas de computador (softwares) responsáveis pelo gerenciamento de uma base de dados

SmartPhone

Telefone celular com funcionalidades avançadas que podem ser estendidas por meio de programas executados por seu sistema operacional, muitos deles abertos, o que permite a criação de um sem números de programas adicionais com diversas utilidades.

SQLite

É uma biblioteca em linguagem $C$ que implementa um banco de dados SQL embutido.

Tablet

Dispositivo pessoal em formato de prancheta que pode ser usado para acesso à Internet, visualização de fotos, vídeos, leitura de textos e ocomo organizador de dados diversos. É um novo conceito: não deve ser igualado a um computador completo ou um smartphone, embora possua funcionalidades de ambos. 
Tipo penal

Tipo penal, forma qualificada

Windows Mobile

Wi-Fi
É como se chama, no Direito Penal, a descrição de um fato ilícito na lei e que, portanto, implica a cominação de uma pena (retribuição).

Enquanto no tipo-base estão descritos todos os elementos que caracterizam o crime, as formas qualificadas são especializações daquele e servem para proporcionar um aumento da pena (no caso das agravantes).

Sistema operacional compacto, desenvolvido para utilização em dispositivos móveis.

Marca comercial registrada da Wi-Fi Alliance. Empregada em produtos certificados que pertencem à classe de dispositivos de rede local sem fios baseados no padrão IEEE. 


\subsection{ANEXOS}

ANEXOS 


\subsection{T e I a (0) - INICIAL}

\section{FORMULÁRIOS}

SENSORES

$\rightarrow 2.0$

$\rightarrow 1.0$

FOTOGRAFIA

$\rightarrow 4.0$

ALTERAR DADOS

$\rightarrow \mathbf{5 . 0}$
ENVIAR / RECEBER

DADOS $\rightarrow 6.0$ 
8.2 T e I a (1.0) - INCIALIZAÇÃO

\section{Administrativo}

$\rightarrow 1.1$

Meio de Acesso ao local $\rightarrow 1.3$

\section{Características da coisa $\rightarrow 1.5$}

\section{Características da}

vitima $\rightarrow \mathbf{1 . 2}$
Meio de Acesso

a coisa $\rightarrow 1.4$

\section{Voltar $\rightarrow \mathbf{0 . 0}$}




\subsection{T e I a (1.1) - DADOS ADMINISTRATIVOS}

RE

(indexador geral - № \#5)

$\mathrm{BO} / \mathrm{TC}$

dado 1.1

( № \#6)

DP

dado 1.2

( № \#1)

DATA (da requisição)

dado 1.3

(default relógio interno) 
HORA (requisição) dado 1.4 (default relógio interno)

DATA (atendimento)

dado 1.5 (dado do relógio interno)

HORA (atendimento) dado 1.6 (dado do relógio interno)

Preservação SIM

NÃO

dado 1.7

Cidade $\longrightarrow$ dädo 1.8

SBC $v=1$ SCS $v=2$ DDA $v=3$

(default SBC = 1) 
Via (Av/rua)

dado 1.9

(Txt - 256 caract)

Número

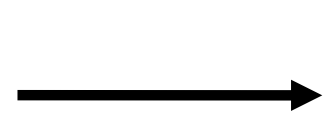

dado 1.10

(№ \#5)

Complemento

dado 1.11

(Txt - 256 caract)

Bairro

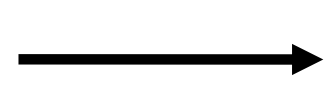

dado 1.12

(Txt - 256 caract)

Latitude

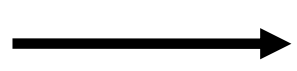

dado 1.13

(dado do GPS)

(dado do GPS) 
8.4 Tela 1.2 - Características das vítimas

TIPO DO IMÓVEL $\quad$ dado 2.1

RESIDÊNCIA $\quad v=1 \quad$ COMERCIO $\quad v=2$ INDÚSTRIA $\quad v=3$

ESCOLA $\quad v=4 \quad$ ESCRITÓRIO $\quad v=5 \quad$ OUTROS $\quad v=6$

(default RESIDÊNCIA v $=1$ )

SITUAÇÃO/ AO TRAFEGO DE VEÍCULOS dado 2.2

ORDINÁRIO $\quad v=1 \quad$ REDUZIDO $\quad v=2$ INTENSO $\quad v=3$

OBSTRUÍDO $\quad v=4 \quad$ OUTROS $\quad v=5$

(default ORDINÁRIO v = 1) 
ORDINÁRIO $v=1$ REDUZIDO $v=2 \quad$ INTENSO $v=3$

RESTRITO $\quad \mathrm{v}=4 \quad$ PROÍBIDO $\quad \mathrm{v}=5 \quad$ OUTROS $\quad \mathrm{v}=6$

(default ORDINÁRIO v = 1)

ILUMINAÇÃO DO FRONTISPÍCIO dado 2.4

ORDINÁRIA $v=1 \quad$ FRACA $\quad \mathrm{v}=2$ EXCELENTE $\quad \mathrm{v}=3$

INEXISTENTE $\mathrm{v}=4$ OUTROS $\quad \mathrm{v}=5$

(default ORDINÁRIA v = 1) 
FOTO PANORÂMICA

dado 2.5

(Câmera do

tablet)

(da via)

VEDAÇÃO FRONTAL

dado 2.6

MURO

$v=1 \quad$ GRADES

$v=2 \quad$ VITRINE

$v=3$

CERCA ARAME $v=4$ CERCA VIVA $v=5$

INEXISTENTE $\quad v=6 \quad$ OUTROS $\quad v=7$

(default MURO v = 1) 
OFENDÍCULAS

INEXISTENTE $\mathrm{v}=0$ dado 2.7

FIOS ELETRIC $\quad \mathrm{v}=3$

C. ESPINHOS $\quad \mathrm{v}=4$

OUTROS $v=5$

(default INEXISTENTE v = 1) 
DEFESAS

dado 2.8

INEXISTENTE $\quad \mathrm{v}=0 \quad$ CACHORRO $\quad \mathrm{v}=1 \quad$ CIRCUITO TV $\quad \mathrm{v}=2$

ALARME $\quad v=3 \quad$ VIGIAS $\quad v=4 \quad$ OUTROS $\quad v=5$

(default INEXISTENTE v = 1)

CONSTRUÇÃO

dado 2.9

TÉRREA

$v=1$

SOBRADO

$v=2$

RÚSTICA

$v=3$

AGLOMERADO $\quad \mathrm{v}=4$

GALPÃO INDUSTRIAL $\quad v=5$

GALPÃO - OFICINA $v=6$

PRÉDIO COMERCIAL $\quad v=7 \quad$ PRÉDIO PÚBLICO $\quad v=8$

OUTROS $\quad v=9$ 
(default CASA COMUM v = 1)

FOTO FRONTAL dado 2.10 (Câmera do tablet)

(do frontispício)

DIMENSÃO FRONTAL dado 2.11

0.0 a $5.1 \mathrm{~m} \quad \mathrm{v}=1 \quad 5.1$ a $10.0 \mathrm{~m} \quad \mathrm{v}=2 \quad 10.1$ a $20.0 \mathrm{~m}$ $v=3$
$20.1 \mathrm{~m}$
$v=4$
OUTROS
$\mathrm{V}=5$

(default 0.0 a $5.1 \mathrm{~m} \mathrm{v}=1$ ) 
OCUPAÇÃO dado 2.12

PERMANENTE $\quad \mathrm{v}=1 \quad \mathrm{H}$. COMERCIAL $\quad \mathrm{v}=2$

DESOCUPADO $\quad v=3$ DESO H. COMER $\quad v=4$

OUTROS $\quad v=5$

(default PERMANENTE $\mathbf{v}=\mathbf{1}$ ) 
8.5 Tela (1.3) - Acesso ao interior do terreno

LIMITE EXTERNO VENCIDO

FRONTAL $\quad \mathrm{v}=1 \quad$ LATERAL $\quad \mathrm{v}=2 \quad$ TRASEIRO $\quad \mathrm{v}=3$

$\begin{array}{lllll}\text { SUPERIOR } \quad \mathrm{v}=4 \quad \text { INFERIOR } \quad \mathrm{v}=5 & \text { OUTROS } \quad \mathrm{v}=6\end{array}$

dado 3.1 (default FRONTAL $v=1$ )

FOTO DO PONTO DE ACESSO dado 3.2 (Câmera do tablet)

(mostrar o meio de entrada) 
ESCALADA dado 3.3

0 VESTÍGIOS $\quad \mathrm{v}=0$ menor $1.20 \mathrm{~m} \quad \mathrm{v}=1 \quad 1.21 \mathrm{a} 1.80 \mathrm{~m} \quad \mathrm{v}=2$

1.81 a $2.40 \quad v=3 \quad 2.41$ a $3.00 m \quad v=4 \quad$ maior $3.00 m \quad v=5$

(default 0 VESTÍGIOS v = 0)

MODO DE ESCALADA dado 3.4

0 VESTÍGIOS $\quad v=0 \quad$ USO MÃO/PÉ $\quad v=1 \quad$ ESCADA $\quad v=2$

CORDA $v=3 \quad$ APOIO COMP $v=4 \quad$ OUTRO $\mathrm{V}=5$

(default 0 VESTÍGIOS v = 0) 
ROMPIMENTO DE OBSTÁCULOS dado 3.5

0 VESTÍGIOS $\quad v=0 \quad$ PORTÃO $\quad v=1 \quad$ PORTA (VIA) $\quad v=2$

JANELA $\quad \mathrm{v}=3$ VITRÔ $\quad \mathrm{v}=4 \quad$ VITRINE $\quad \mathrm{v}=$
5

MURO

$$
v=6 \quad \text { GRADES }
$$

$\mathrm{V}=7 \quad \mathrm{CERCA}$ $\mathrm{V}=$ 8

TELHADO $v=9$ LAJE TETO $v=10$ OUTROS $v=$ 11

(default 0 VESTÍGIOS $\mathrm{v}=0$ ) 
MODO DO ROMPIMENTO

0 VESTÍGIOS $\quad \mathrm{v}=0$

GUISA ALAVANCA $v=2$ GUISA DE CORTE $v=3$ dado 3.6

GUISA DE MASSA $\quad v=1$

GUISA DE FORÇA $\quad v=4 \quad$ OUTROS $\quad v=5$

(default 0 VESTÍGIOS $v=0$ )

USO DE CHAVE FALSA dado 3.7 
0 VESTÍGIOS $v=0$ RANHURAS NA FECHADURA $v=$ 1

USO CHAVE MESTRA $\quad v=2$ ABUSO CONFIANÇA $\quad v=$ 3

OUTROS

$$
v=4
$$

(default 0 VESTÍGIOS $\mathrm{v}=0$ )

CLOSE UP DO VESTÍGIO

dado 3.8

(Câmera

externa)

(foto precisa do vestígio)

(pegada / impressão digital

Marca de ferramenta) 
8.6 Trela (1.4) - Acesso à coisa

RESIDÊNCIA

1ำ COMODO INVADIDO

dado 4.1

0 VESTÍGIOS $v=0 \quad$ Sala frontal $\quad v=1 \quad$ Cozinha $\quad v=2$

Quarto $v=3 \quad$ Banheiro $\quad v=4 \quad$ Outro $\mathrm{V}=5$

(default 0 VESTÍGIOS v = 0) 
ATUAÇÃO DO INVASOR d dado 4.2

(Moveu/ Remexeu)

0 VESTÍGIOS $\quad \mathrm{v}=0$ Gavetas $\mathrm{v}=1$ Roupas $\mathrm{v}=2$

Alimentos $\mathrm{V}=3$ Eletrodomésticos $\mathrm{V}=4$ Armários $\mathrm{v}=5$

Outros $\quad v=6 \quad$ (default 0 VESTÍGIOS $v=0$ )

FOTO DA MOVIMENTAÇÃO dado 4.3 (Câmera tablet)

(foto da situação do cômodo)

FOTO DO VESTÍGIO COLETADO dado 4.4 (Câmera externa)

(Close-up do vestígio)

OUTROS COMODOS INVADIDOS dado 4.5

0 VESTÍGIOS $v=0 \quad$ Sala frontal $\quad v=1 \quad$ Cozinha $\quad v=2$

Quarto $v=3 \quad$ Banheiro $\quad v=4 \quad$ Outro $\quad v=5$

(default 0 VESTÍGIOS v = 0) 
COMÉRCIO

1을 AMBIENTE INVADIDO

0 VESTÍGIOS $\quad \mathrm{v}=0 \quad$ Frontal

Traseiro

$v=3$

Garagem $\mathrm{v}=1 \quad$ Lateral

$\mathrm{V}=2$

dado 4.6

$$
v=4 \quad \text { Outro }
$$
$\mathrm{v}=5$

(default 0 VESTÍGIOS v = 0)

ATUAÇÃO DO INVASOR dado 4.7

(Moveu/ Remexeu)

0 VESTíGIOS $\quad \mathrm{v}=0$ Gavetas $\quad \mathrm{v}=1 \quad$ Cofre $\quad \mathrm{v}=2$

Mostruário $v=3 \quad$ Computadores $\quad \mathrm{v}=4 \quad$ Armários $\quad \mathrm{v}=5$

Outros $v=6 \quad$ (default 0 VESTíGIOS v =0) 
(foto da situação do cômodo)

FOTO DO VESTÍGIO COLETADO dado 4.9 (Câmera externa) (Close-up do vestígio)

Traseiro

$$
v=3 \quad \text { Garagem }
$$

$\mathrm{V}=4$

Outro $\mathrm{V}=5$

(default 0 VESTÍGIOS v = 0) 
ATUAÇÃO DO INVASOR dado 4.11

(Moveu/ Remexeu)

0 VEstígIOS $\quad \mathrm{v}=0$ Gavetas $\quad \mathrm{v}=1 \quad$ Cofre $\quad \mathrm{v}=2$

Mostruário $\mathrm{v}=3 \quad$ Computadores $\quad \mathrm{v}=4$ Armários $\mathrm{v}=5$

Outros $\quad v=6 \quad$ (default 0 VESTÍGIOS v =0)

FOTO DA MOVIMENTAÇÃO dado 4.12 (Câmera tablet)

(foto da situação do cômodo)

FOTO DO VESTíGIO COLETADO dado 4.13 (Câmera externa)

(Close-up do vestígio)

INDÚSTRIA

1ำ AMBIENTE INVADIDO dado 4.14 
0 VESTÍGIOS $v=0 \quad$ Escritórios $\quad v=1 \quad$ Oficina $\quad v=2$

Depósito

$v=3 \quad$ Garagem

$v=4 \quad$ Outro

$\mathrm{V}=5$

(default 0 VESTÍGIOS v = 0)
ATUAÇÃO DO INVASOR
dado 4.15
(Moveu/ Remexeu)

0 VESTÍGIOS $\quad \mathrm{v}=0$ Gavetas $\quad \mathrm{v}=1$ Cofre $\quad \mathrm{v}=2$

Instrumentos $v=3 \quad$ Computadores $v=4 \quad$ Ferramentas $v=5$

Outros $v=6 \quad$ (default 0 VESTÍGIOS $v=0$ )

FOTO DA MOVIMENTAÇÃO dado 4.16 (Câmera tablet)

(foto da situação do cômodo) 
FOTO DO VESTÍGIO COLETADO

dado 4.17 (Câmera externa)

(Close-up do vestígio)

OUTROS AMBIENTES INVADIDOS

dado 4.18

0 VESTíGIOS $\quad \mathrm{v}=0 \quad$ Escritórios $\quad \mathrm{v}=1 \quad$ Oficina $\quad \mathrm{v}=2$

Depósito

$$
v=3 \quad \text { Garagem }
$$

$\mathrm{V}=4$

Outro

$\mathrm{v}=5$

(default 0 VESTÍGIOS v = 0) 
ATUAÇÃO DO INVASOR d dado 4.19

(Moveu/ Remexeu)

0 VESTÍGIOS $\quad \mathrm{v}=0$ Gavetas $\quad \mathrm{v}=1 \quad$ Cofre $\quad \mathrm{v}=2$

Instrumentos $v=3 \quad$ Computadores $v=4 \quad$ Ferramentas $v=5$

Outros $\quad v=6 \quad$ (default 0 VESTÍGIOS v =0)

FOTO DA MOVIMENTAÇÃO dado 4.20 (Câmera tablet)

(foto da situação do cômodo)

FOTO DO VESTÍGIO COLETADO dado 4.21 (Câmera externa)

(Close-up do vestígio)

ESCOLA 
0 VESTÍGIOS $\mathrm{v}=0$ Frontal $\quad \mathrm{v}=1 \quad$ Lateral $\quad \mathrm{v}=2$

Traseiro $v=3 \quad$ Garagem $\quad v=4 \quad$ Outro $v=5$

(default 0 VESTÍGIOS v = 0)

ATUAÇÃO DO INVASOR dado 4.23

(Moveu/ Remexeu)

0 VESTÍGIOS $\quad \mathrm{v}=0$ Gavetas $\quad \mathrm{v}=1 \quad$ Armários $\quad \mathrm{v}=2$

Eletrônicos $\mathrm{v}=3 \quad$ Computadores $\quad \mathrm{v}=4 \quad$ Alimentos $\mathrm{v}=5$

Outros $\quad \mathrm{v}=6 \quad$ (default 0 VESTÍGIOS v $=0$ ) 
FOTO DA MOVIMENTAÇÃO

(foto da situação do cômodo)

FOTO DO VESTÍGIO COLETADO externa)

(Close-up do vestígio)

OUTROS AMBIENTES INVADIDOS

dado 4.26

0 VESTÍGIOS $v=0 \quad$ Frontal

$\mathrm{V}=1 \quad$ Lateral

$\mathrm{V}=2$

Traseiro

$v=3 \quad$ Garagem

$\mathrm{V}=4$

Outro dado 4.24 (Câmera tablet)

dado 4.25 (Câmera

$\mathrm{V}=5$

(default 0 VESTÍGIOS v = 0) 


\section{ATUAÇÃO DO INVASOR dado 4.27}

(Moveu/ Remexeu)

0 VESTíGIOS $\quad \mathrm{v}=0$ Gavetas $\quad \mathrm{v}=1 \quad$ Armários $\quad \mathrm{v}=2$

Eletrônicos $v=3 \quad$ Computadores $\quad v=4 \quad$ Alimentos $v=5$

Outros $\quad v=6 \quad$ (default 0 VESTÍGIOS v =0)

FOTO DA MOVIMENTAÇÃO dado 4.28 (Câmera tablet)

(foto da situação do cômodo)

FOTO DO VESTÍGIO COLETADO dado 4.29 (Câmera externa)

(Close-up do vestígio)

ESCRITÓRIO

1ำ AMBIENTE INVADIDO dado 4.30 
0 VESTÍGIOS $\mathrm{v}=0$ Frontal $\quad \mathrm{v}=1 \quad$ Lateral $\quad \mathrm{v}=2$

Traseiro

$$
v=3 \quad \text { Garagem }
$$

$v=4 \quad$ Outro $\mathrm{V}=5$

(default 0 VESTÍGIOS v = 0)

ATUAÇÃO DO INVASOR dado 4.31

(Moveu/ Remexeu)

0 VESTÍGIOS $\quad \mathrm{v}=0$ Gavetas $\quad \mathrm{v}=1 \quad$ Armários $\quad \mathrm{v}=2$

Eletrônicos $\mathrm{v}=3 \quad$ Computadores $\quad \mathrm{v}=4 \quad$ Alimentos $\mathrm{v}=5$

Outros $\quad \mathrm{v}=6 \quad$ (default 0 VESTÍGIOS v =0)

FOTO DA MOVIMENTAÇÃO dado 4.32 (Câmera tablet)

(foto da situação do cômodo) 
FOTO DO VESTÍGIO COLETADO

dado 4.33 (Câmera externa)

(Close-up do vestígio)

0 VESTíGIOS $\quad \mathrm{v}=0 \quad$ Salas/chefia $\quad \mathrm{v}=1 \quad$ Salas/Funcionários $\mathrm{V}=2$

Dispensas

$v=3 \quad$ Garagem

$\mathrm{V}=4$

Outro

$\mathrm{V}=5$

(default 0 VESTíGIOS v = 0) 
ATUAÇÃO DO INVASOR dado 4.35

(Moveu/ Remexeu)

0 VESTÍGIOS $\quad \mathrm{v}=0$ Gavetas $\quad \mathrm{v}=1 \quad$ Armários $\quad \mathrm{v}=2$

Eletrônicos $\mathrm{v}=3 \quad$ Computadores $\quad \mathrm{v}=4 \quad$ Alimentos $\mathrm{v}=5$

Outros $\quad v=6 \quad$ (default 0 VESTÍGIOS v =0)

FOTO DA MOVIMENTAÇÃO dado 4.36 (Câmera tablet)

(foto da situação do cômodo)

FOTO DO VESTÍGIO COLETADO dado 4.37 (Câmera externa)

(Close-up do vestígio) 
8.7 Tela (1.5) - Descrição da coisa

0 VESTÍGIOS $\quad v=0 \quad$ Organizada $\quad v=1 \quad$ Não organizada $\mathrm{V}=2$

(default 0 VESTÍGIOS v = 0)

VISIBILADE DA COISA FURTADA dado 5.2

Imediata $\mathrm{v}=1$ Abertura de gavetas $\mathrm{v}=2$ Abertura de armários $\mathrm{v}=$ 3

Rompimento cofre $\quad \mathrm{v}=4$ Dissimulada $\mathrm{v}=5$

(default Imediata $v=1$ )

TIPO PRINCIPAL DA COISA FURTADA dado 5.3 
Jóias

$$
v=1
$$

Armas

$\mathrm{V}=2$

Vestes

$\mathrm{V}=3$

Eletrodomésticos $\quad \mathrm{v}=4 \quad$ Computadores $\mathrm{v}=5 \quad$ Eletrônicos $\mathrm{v}=6$

Ferramentas $\quad v=7$ Instrumentos $\quad v=8 \quad$ Peças de Veículos $\mathrm{v}=9$

Grades Metálicas $v=10 \quad$ Fios $v=11 \quad$ Outros $\quad v=$ 12

(default Jóias v = 1)

Jóias

$$
\mathrm{v}=1 \quad \text { Armas/muni } \mathrm{v}=2 \quad \text { Vestes }
$$

$v=3$

Eletrodomésticos $\quad \mathrm{v}=4 \quad$ Computadores $v=5 \quad$ Eletrônicos $\mathrm{V}=6$ 
Ferramentas $\quad v=7$ Instrumentos $\quad v=8 \quad$ Peças de Veículos $\mathrm{V}=9$

Grades Metálicas $v=10$ Fios $v=11$ Meios/transporte da coisa $\mathrm{V}=12$

Outros $\quad v=13$

(default Jóias v = 1) 
MAIOR DIMENSÃO dado 5.5

Menor $0.1 \mathrm{~m} \quad \mathrm{v}=1 \quad 0.11 \mathrm{a} 0.30 \quad \mathrm{v}=2 \quad 0.31$ a $0.60 \quad \mathrm{v}=3$

0.61 a $1.00 \mathrm{~m} \quad \mathrm{v}=4 \quad 1.00$ a $1.50 \quad \mathrm{v}=5 \quad$ maior $1.51 \mathrm{~m} \quad \mathrm{v}=6$

(default Menor $0.1 \mathrm{~m} v=1$ )

PESO TOTAL dado 5.6

Menor $0.20 \mathrm{~kg} \quad \mathrm{v}=1 \quad 0.20$ a $1.00 \quad \mathrm{v}=2 \quad 1.10$ a $10.00 \quad \mathrm{v}=3$

10.1 a $30.0 \quad v=4 \quad 30.1$ a $60.0 \quad v=5 \quad$ maior $60.0 \mathrm{~kg} \quad \mathrm{v}=6$

(default Menor $0.20 \mathrm{~kg} v=1$ ) 
MECANISMO DE TRANSPORTE dado 5.7

Manual $v=1$ Sacolas $v=2$ Sacos Plásticos $v=3$

Malas $\quad \mathrm{v}=4$ caixas papelão $\mathrm{v}=5$ Veículos $\quad \mathrm{V}=6$

Outros $\quad v=7$

(default Manual $\mathbf{v}=1$ )

VESTÍGIOS ENCONTRADOS dado 5.8

0 VESTÍGIOS $\mathrm{v}=0$ Digitais $\mathrm{v}=1 \quad$ Pegadas $\quad \mathrm{v}=2$

Marcas pneus $\quad \mathrm{v}=3$ ferramentas $\quad \mathrm{v}=4$ arrastamento $\quad \mathrm{v}=5$

Outros $\quad v=6$

(default 0 VESTÍGIOS $v=0$ ) 
8.8 Tela (2.0) - Medidas

FLUÍDOS CORPÓREOS dado 5.9

0 VESTÍGIOS $v=0 \quad$ Saliva $\quad v=1 \quad$ Fezes/Urina $\quad v=2$

Esperma $\quad v=3 \quad$ Sangue $\quad v=4$ Outros $\quad v=5$

(default 0 VESTÍGIOS $v=0$ ) 